
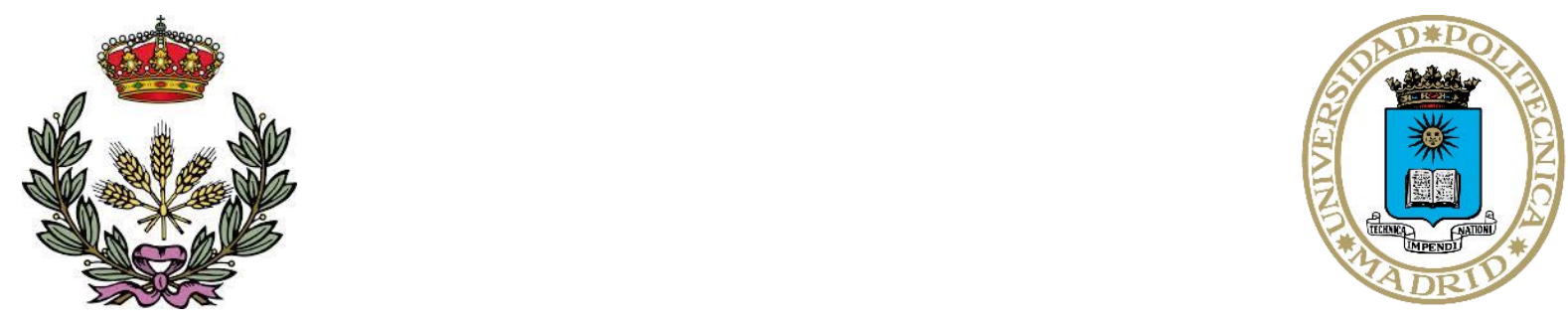

Departamento de Economía Agraria, Estadística y Gestión de Empresas

Escuela Técnica Superior de Ingeniería Agronómica, Alimentaria y de Biosistemas

Universidad Politécnica de Madrid

\title{
Sustainable agriculture and resource use under climate change: a multi-scale and cross-sectoral approach with a focus on Andalusia (Spain)
}

\author{
Tesis Doctoral \\ Maria Pilar Martinez Muñoz \\ Ingeniera Agrónoma \\ Directora \\ Maria Blanco Fonseca \\ Dr. Ingeniero Agrónomo
}

Madrid, 2019 



\section{POLITÉCNICA}

Tribunal nombrado por el Sr. Rector Magfco. de la Universidad Politécnica de Madrid, el día de de $201 \ldots$

Presidente:

Vocal:

Vocal:

Vocal:

Secretario:

Suplente:

Suplente:

Realizado el acto de defensa y lectura de la Tesis el día ...... de de $201 \ldots$ en la E.T.S.I./Facultad

Calificación

EL PRESIDENTE

LOS VOCALES

\section{EL SECRETARIO}



A mi familia y amigos 



\section{Agradecimientos}

La realización de esta tesis doctoral no habría sido posible sin la contribución y el apoyo de numeras personas a las que me gustaría mostrar mi agradecimiento en estas líneas.

En primer lugar, me gustaría dar las gracias a mi directora de tesis, Maria Blanco, por confiar en mí y darme la oportunidad de formar parte de su equipo. Durante estos cinco años, su apoyo para desarrollar esta investigación ha sido constante. Siempre le estaré agradecida por animarme a confiar en mí y por fomentar mi búsqueda de la perfección. Además, gracias a ella he podido participar en diversos proyectos de investigación que han sido una valiosa fuente de conocimiento y experiencias.

Entre estos proyectos, me gustaría agradecer a TRUSTEE, SIM4NEXUS y SYNERCAP por la financiación de esta investigación, así como por la experiencia profesional y personal que han supuesto para mí. Aprovecho para dar las gracias a todos los compañeros de los proyectos en los que he participado por ser un referente y una inspiración. Muchas gracias también a los miembros de la red del modelo CAPRI por el esfuerzo dedicado a la organización de cursos técnicos anuales, así como cursos específicos para los nuevos miembros de la red, que han sido esenciales para aplicar el modelo en esta investigación.

Mi más sincero agradecimiento a todos los grupos de interés de Andalucía por su disponibilidad, interés y participación en las entrevistas y los talleres realizados en el caso de estudio. En particular, me gustaría dar las gracias a la Consejería de Agricultura, Pesca y Desarrollo Rural de la Junta de Andalucía por ofrecernos un lugar en el que realizar los talleres e involucrase en la organización.

Quiero agradecer también a James Breen, mi supervisor durante mi estancia predoctoral en University College of Dublin (Irlanda), por acogerme en su equipo, por su amabilidad y por su ayuda durante los tres meses que pasé en Dublín.

Agradecer también a los equipos directivos del Departamento de Economía Agraria, Estadística y Gestión de Empresas, así como del CEIGRAM por su compromiso con la formación a través de la organización de jornadas, seminario y cursos que me han ayudado adquirir conocimientos que han enriquecido esta tesis. Muchas gracias también al equipo coordinador del doctorado TAPAS y, muy especialmente, a Carmen Diéguez por toda su ayuda y su tiempo. 
Además, me gustaría agradecer el apoyo recibido por parte de todos los compañeros con los que he tenido el placer de trabajar y compartir momentos durante estos cinco años: Paloma, Irene, Francisco, Silvestre, Cristhian, Lucian, Zhiyang Yin, Marina, Luis, Yuanbo, Maritza, Paula, Roge, Adrián, Marta, Inés, Wookhyun, Sebas, Najib, Debbora, Berta y Axel. Agradecer particularmente a mi compañera Bente su ayuda para la realización del proceso participativo con los grupos de interés. Además, me gustaría hacer una mención especial a dos personas sin las que esta aventura no habría sido lo mismo. A mi compañero de despacho y amigo, Rhys, gracias por recordarme lo importante que es seguir lo principios propios, por su ayuda y por las clases de inglés improvisadas. A mi compañero de todo y hermano, Castaño, gracias por demostrarme que nunca hay que dejar de creer, por su ayuda incondicional y por ponerle color a mi vida y a esta tesis.

A todos mis amigos, gracias por acompañarme y por animarme durante todo este tiempo. En particular, me gustaría dar las gracias a Marga y David, por transmitirme calma y serenidad, por su apoyo siempre y muy especialmente estos últimos meses. A Sandra y Carlos, por estar siempre. A Ana, Chiqui y Cris, por ser mi fuente de energía. A Gaby, Oscar, Dolce y Ceci por transmitirme sabiduría y tranquilidad. A todos mis 'lowers', por los ánimos que me habéis dado. A Irene y Patri por su apoyo. A Lucia y Maca, por parar el tiempo cada vez que nos vemos. A Maite, Grace y Paulette, por ser una inspiración para mí y por sus sabios consejos. A Grace, muchas gracias además por su maravillosa revisión de inglés de este documento.

A mi familia, no hay palabras que puedan expresar lo agradecida que estoy por vuestro apoyo incondicional en todas las decisiones que he tomado a lo largo de mi vida y que, de alguna manera, me han conducido hasta aquí. A mis padres, Jerónimo y Pilar, gracias por su esfuerzo y por educarme en los valores de la responsabilidad, la generosidad y la humildad. A mi hermano Miguel, gracias por ser un ejemplo para mí y por estar siempre. A mi hermano José, gracias por transmitirme sus inquietudes por la ciencia. A mis sobrinos, Pablo, Lidia y Alejandro, gracias por contagiarme su alegría y por invitarme a soñar.

Aunque son todos los que están, posiblemente no estén todos los que son. A todas las personas que han contribuido de alguna manera a la realización de esta tesis:

¡Muchas gracias! 


\section{Abstract}

The sustainability of agricultural and food systems is confronted with different challenges that need to be addressed to ensure future food security and environmental preservation. Crop production is very sensitive to climatic conditions and therefore is extremely exposed to climate change impacts on both crop productivity and water availability. In addition, expected future socioeconomic development is likely to add more pressure on resources and drive conflicts between the different sectors. Meanwhile, policies that tackle these challenges are often developed in isolation without regarding cross-sectoral effects, leading to policy incoherence. This demonstrates the need for integrated and harmonised policies that consider trade-offs and synergies across sectors, which requires involving stakeholders and knowledge sharing between decision-makers and the scientific community to frame better informed policies.

In this context, this research aims to broaden knowledge on the interrelations between agriculture and the environment to support policy decision-making that promotes sustainable agricultural development and resource use under climate change. Addressing global climate change impacts requires the implementation of strategies at regional level to account for region-specific effects and cross-sectoral connections. In recognition of this, the investigation explores firstly climate change impact on agricultural markets at global and European Union (EU) levels. Then, the scope of the analysis is extended to explore the water-energy-food (WEF) nexus, while at the same time the scale is reduced to the region of Andalusia (Spain).

The applied methodological framework draws on the combination of bio-economic modelling, participatory approaches and sensitivity analysis techniques. The bio-economic modelling approach builds on the agro-economic Common Agricultural Policy Regional Impact Analysis model (CAPRI) to assess climate change impacts on agri-food markets at global and EU levels under multiple scenarios that consider different emissions pathways, climate projections and carbon fertilisation effects on crop growth. Through a participatory approach based on Fuzzy Cognitive Mapping (FCM), regional stakeholders from Andalusia were engaged to identify main challenges in the WEF nexus. Additionally, information gathered from this stakeholder consultation process provided the foundation to disentangle key water-related drivers of agricultural development in Andalusia over the temporal horizon of 2050, based on CAPRIWater outcomes and sensitivity analysis with finite changes.

The modelling results show that climate change would considerably affect agri-food markets, although market-driven adaptation strategies (e.g., production intensification, trade 
adjustments) would soften the impact of yield shocks on supply and demand. As a result, regional changes in production would be lower than those foreseen by other studies focused on supply effects. The results from the participatory process with stakeholders indicate that climate change and water availability are key drivers in the WEF nexus in Andalusia. Other variables with important interlinkages within the WEF nexus are food production, irrigated agriculture, energy cost, socioeconomic factors, irrigation water use and environmental conservation. The scenario analysis reveals the interdependencies among nexus sectors and the existence of unanticipated effects when changing variables in the system, which need to be considered to design integrated policies. The sensitivity analysis of the CAPRI-Water results illustrates that irrigation costs are the most determinant factor in shaping agricultural land, offsetting the impact of the driver water availability. In contrast, irrigation water use is driven not only by irrigation costs but also by irrigation efficiency.

The main findings indicate that carbon fertilisation effect is a key factor on the impact of climate change on agriculture and that international trade plays an important role to counterbalance uneven impacts across the world. This suggests that decision-makers must engage to guarantee the coherence between trade regulations and climate policies. The participatory approach reveals that climate change and water availability are the main drivers in the WEF nexus in Andalusia. The sensitivity analysis of the CAPRI-Water results demonstrate that irrigation costs are the most determining factor in shaping agricultural land, with the magnitude of the sensitivity to this driver differing across crops. Identifying the main drivers of future agricultural development provides meaningful information for developing policies that effectively enhance sustainable agriculture and water management in Andalusia. Policies aimed at improving resource use efficiency can contribute to strengthen the resilience and adaptation capacity of future agricultural systems to climate change. Nevertheless, they must consider crop sensitivity to irrigation costs and the potential rebound effect. 


\section{Resumen}

La sostenibilidad de los sistemas agrarios y alimentarios se enfrenta a diferentes retos que necesitan ser abordados para asegurar la seguridad alimentaria y la preservación del medio ambiente en el futuro. La producción agraria es muy sensible a las condiciones climáticas y, por lo tanto, está extremadamente expuesta a los impactos del cambio climático en la productividad de los cultivos y en la disponibilidad de agua. Además, se espera que el desarrollo socio-económico futuro añada más presión sobre los recursos y genere conflictos entre los distintos sectores. Mientras tanto, las políticas que abordan estos desafíos a menudo se diseñan de forma aislada sin tener en cuenta los efectos intersectoriales, lo que conduce a la existencia de incoherencias entre políticas. Esto evidencia la necesidad de desarrollar políticas integradas y armonizadas que consideren los conflictos y las sinergias entre los sectores, lo que requiere la participación de las partes interesadas y también el intercambio de conocimientos entre los responsables de la toma de decisiones y la comunidad científica para diseñar políticas mejor informadas.

En este contexto, esta investigación tiene como objetivo ampliar el conocimiento sobre las interrelaciones entre la agricultura y el medio ambiente para apoyar la toma de decisiones políticas que promuevan el desarrollo sostenible de la agricultura y el uso eficiente de recursos bajo condiciones de cambio climático. En este sentido, abordar los impactos del cambio climático a nivel global requiere implementar estrategias a menor escala que tengan en cuenta los efectos específicos en cada región y las interrelaciones entre los distintos sectores. Teniendo esto en cuenta, esta investigación analiza en primer lugar el impacto del cambio climático en los mercados agrarios a nivel mundial y en la Unión Europea. Posteriormente, el alcance del análisis se amplía para explorar el nexo agua-energía-alimentación (WEF), mientras que al mismo tiempo la escala de análisis se reduce a la región de Andalucía (España).

El marco metodológico aplicado se basa en la combinación de enfoques bio-económicos, procesos participativos y técnicas de análisis de sensibilidad. El enfoque bio-económico se basa en la aplicación del modelo agro-económico (Common Agricultural Policy Regional Impact Analysis model [CAPRI]) para evaluar los impactos del cambio climático en los mercados agroalimentarios a nivel mundial y en la Unión Europea bajo distintos escenarios que consideran diferentes trayectorias de emisiones, proyecciones climáticas y efectos de la fertilización carbónica en el crecimiento de los cultivos. A través de un enfoque participativo basado en Fuzzy Cognitive Mapping (FCM), los grupos de interés en Andalucía participaron en la identificación de los principales retos en el nexo en la región. Además, la información 
obtenida en este proceso participativo proporcionó las bases para identificar los principales factores relacionados con el uso de agua en el desarrollo de la agricultura andaluza en el horizonte 2050, utilizando como base los resultados de CAPRI-Water y análisis sensibilidad con cambios finitos.

Los resultados de esta investigación muestran que el cambio climático afectará significativamente los mercados agroalimentarios, aunque las estrategias de adaptación impulsadas por el mercado (e.g., intensificación de la producción, ajustes comerciales) pueden atenuar los impactos. Como consecuencia, los cambios de producción a nivel regional serán inferiores a los estimados en otros estudios centrados en los efectos en la oferta. En cuanto al proceso participativo con los grupos de interés, los resultados indican que el cambio climático y la disponibilidad de agua son factores clave en el nexo en Andalucía. Otras variables con vínculos significativos dentro del nexo WEF son la producción de alimentos, la agricultura de regadío, el coste de la energía, los factores socioeconómicos, el uso del agua de riego y la conservación del medio ambiente. El análisis de escenarios demuestra la existencia de interdependencias en el nexo y de efectos imprevistos, que deben considerarse para diseñar políticas integradas. El análisis de sensibilidad de los resultados de CAPRI-Water ilustra que los costes del regadío con el factor más determinante en la configuración del paisaje agrario andaluz, neutralizando el impacto del factor disponibilidad de agua. En cambio, el uso del agua para riego no solo está influenciado por los costes del regadío, sino también por la eficiencia en el uso de agua.

Las conclusiones indican que la fertilización carbónica es un factor fundamental a tener en cuenta en los análisis del impacto del cambio climático en la agricultura y que el comercio internacional juega un papel importante para contrarrestar la irregularidad de los impactos a nivel mundial, lo que sugiere la necesidad de coherencia entre las políticas comerciales y climáticas. El enfoque participativo revela que el cambio climático y la disponibilidad de agua son factores clave en el nexo en Andalucía. El análisis de sensibilidad de los resultados de CAPRI-Water demuestra que los costes del regadío son el factor más determinante en desarrollo de la agricultura andaluza, y que la magnitud de la sensibilidad a este factor difiere considerablemente entre cultivos. Las políticas destinadas a la mejora de la eficiencia en el uso de los recursos pueden contribuir a incrementar la resiliencia y capacidad de adaptación de los sistemas agrarios al cambio climático, aunque deben considerar la sensibilidad de las producciones agrarias a los costes del regadío, así como posibles efectos rebote en el uso de los recursos. 


\section{Table of Contents}

Agradecimientos i

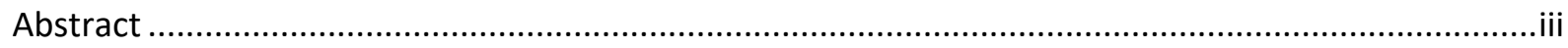

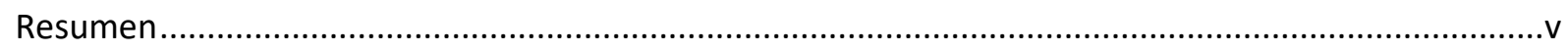

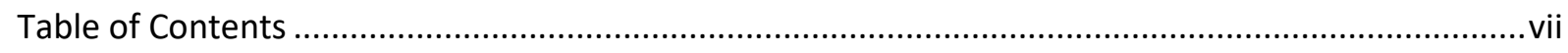

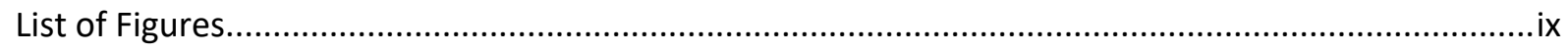

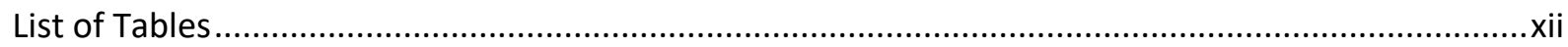

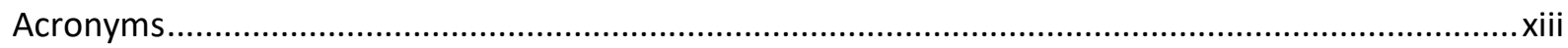

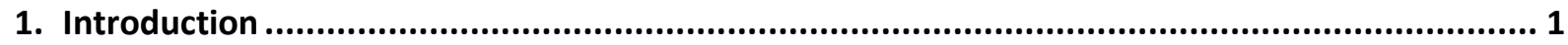

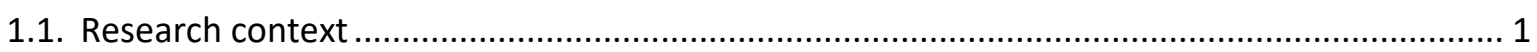

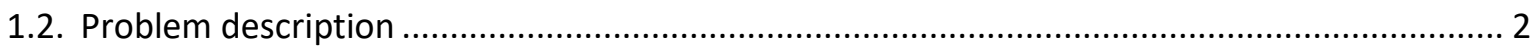

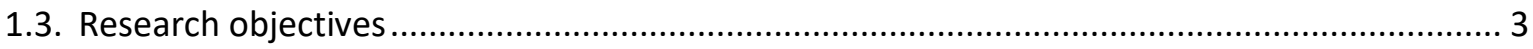

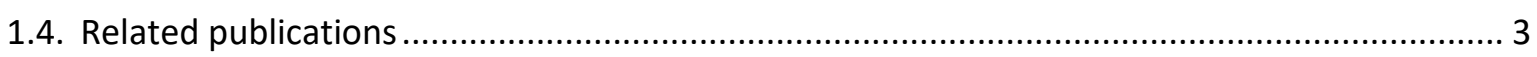

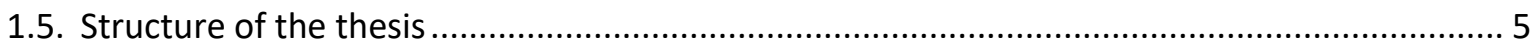

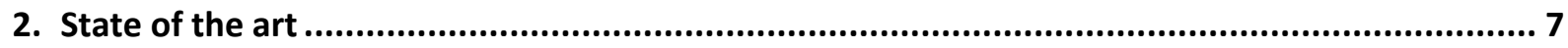

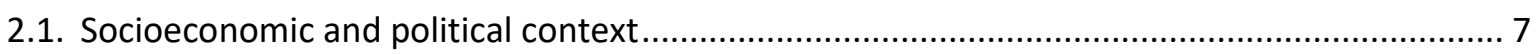

2.1.1. Agriculture and food systems: current status and future trends............................... 7

2.1.2. Strategies for agriculture and food towards 2050 .................................................... 8

2.2. Climate change research: scenario framework ................................................................. 9

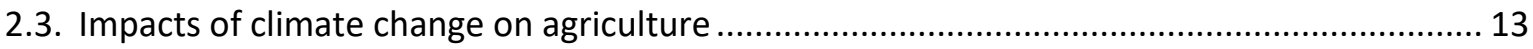

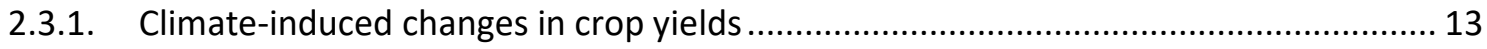

2.3.2. Climate change impacts on agricultural markets: the role of trade ............................. 15

2.3.3. Climate change impacts on water resources: implications for irrigation ...................... 16

2.4. Sustainable resource management: Water-Energy-Food (WEF) nexus ................................... 18

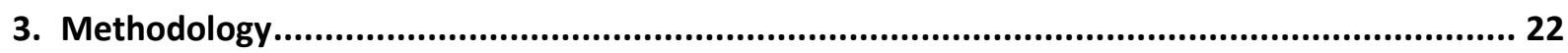

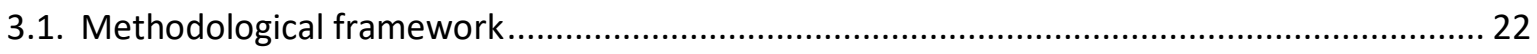

3.2. Impacts of climate change in agricultural markets: Bio-economic modelling approach .......... 26

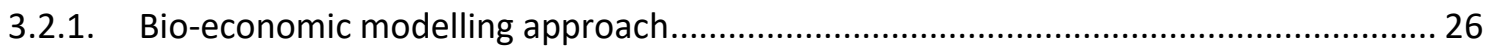

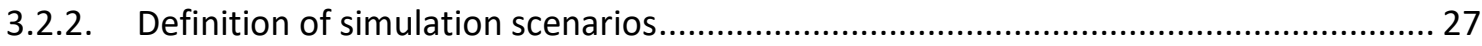

3.3. Understanding interconnections within the WEF nexus: Fuzzy cognitive mapping ................ 29

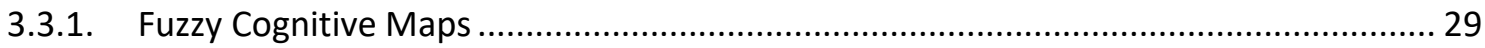

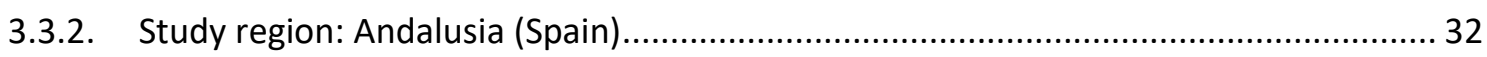

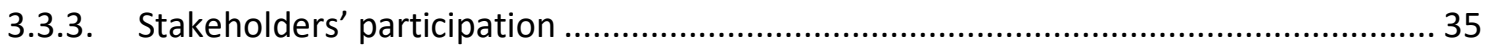




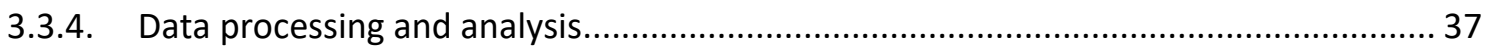

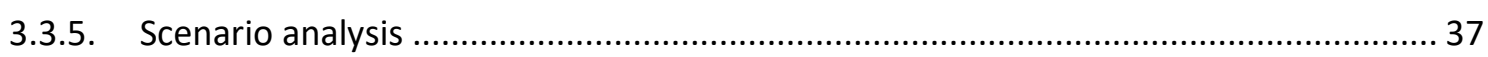

3.4. Disentangling key water-related drivers of future agricultural development: Sensitivity analysis

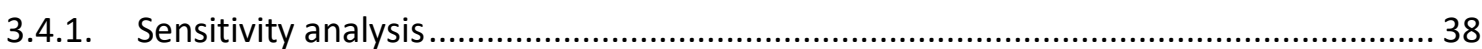

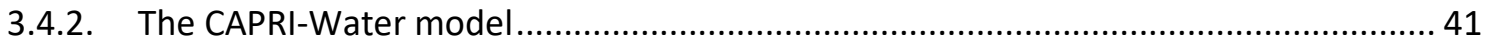

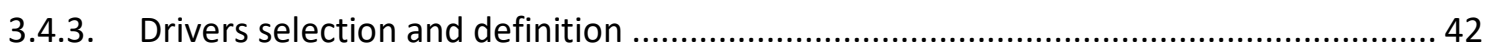

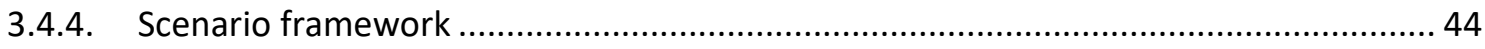

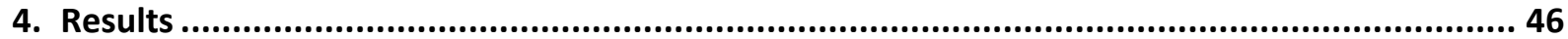

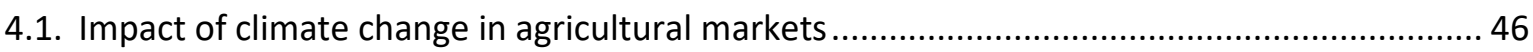

4.1.1. Climate-induced effects on global agricultural production and prices .......................... 46

4.1.2. Climate-induced effects on agricultural production for main traders .......................... 48

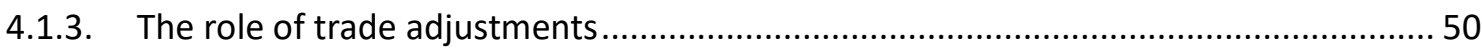

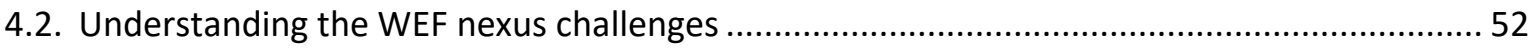

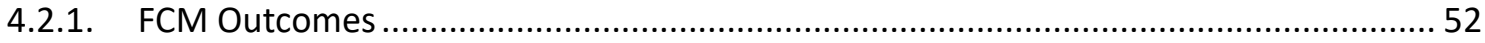

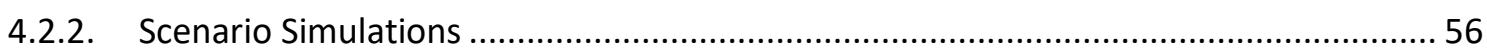

4.3. Disentangling key water-related drivers of future agricultural development ......................... 58

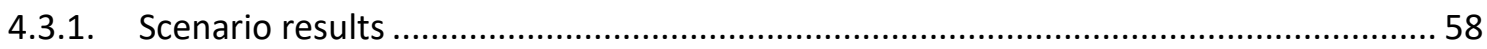

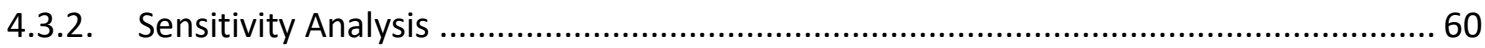

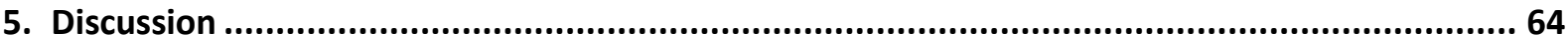

6. Conclusions

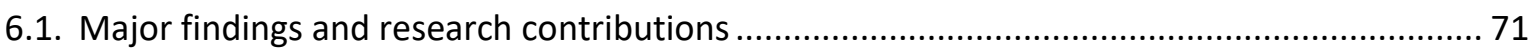

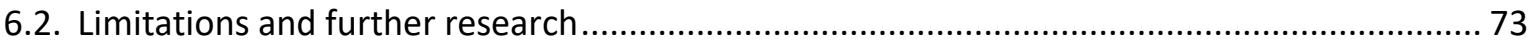

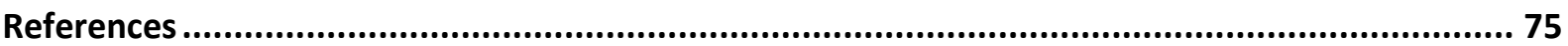

Annexes

Annex 1: LPJmL and WOFOST simulated yields changes in 2030 for wheat, maize, soybean and rapeseed under different climate scenarios (\% change relative to baseline). 96

Annex 2: Wheat exports from major exporters under different climate scenarios (\% change relative to baseline in 2030). Baseline values in thousand tons. Source: CAPRI model................. 97

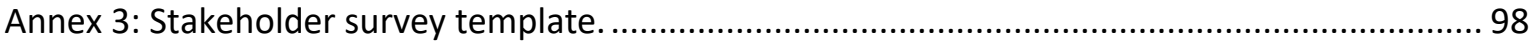

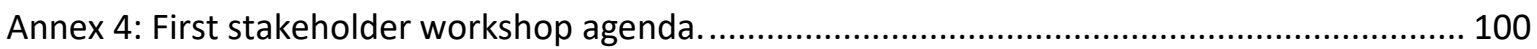

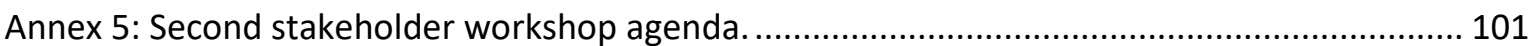




\section{List of Figures}

Figure 1: Total radiative forcing (left) and cumulative carbon emissions since 1751 (right) in baseline scenario literature compared to RCP scenarios. Secondary axis in the left panel expresses forcing in CO2eq concentrations. Scenarios are depicted as ranges with median emboldened; shading reflects interquartile range (darkest), 5th - 95th percentile range (lighter), and full extremes (lightest)........ 10

Figure 2: Projected changes in average surface temperature (a) and average precipitation (b) for 2081-2100 relative to 1986-2005 under the RCP 2.6 (left) and RCP 8.5 (right) scenarios from multimodel mean projections.

Figure 3: SSPs challenge to mitigation and adaptation.

Figure 4: Impacts of climate change on average yields based on a literature review categorised by region (temperate vs. tropical regions), modelling approach (process-based vs. statistical), carbon fertilisation effects, and crops. Numbers in parentheses depicts the number of estimates. Value in percentage change per decade. Source: IPCC (2013).

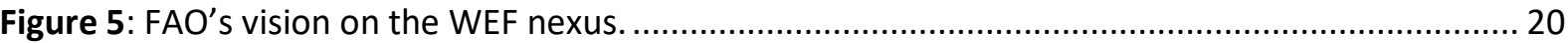

Figure 6: Methodological framework of the thesis research.

Figure 7: Bio-economic modelling approach. RCP (Representative Concentration Pathway); SSP (Share Socioeconomic Pathway); CAPRI (Common Agricultural Policy Regional Impact Analysis Model).

Figure 8: Location of Andalusia and main types of land use.

Figure 9: Example of an individual map drawn by stakeholders. Boxes represent the variables identified by the stakeholder. Arrows depict the cause-effect relationship between variables. Number values represent the strength of the causal relationship, where the sign depicts a positive $(+)$ or negative $(-)$ causal relationship and the value between 0 and 1 represents the magnitude..... 36

Figure 10: LPJmL-simulated global yields changes in 2030 for wheat, maize, rapeseed and soybean under different simulation scenarios.

Figure 11: Changes in a) global production and b) global prices in 2030 for wheat, maize, rapeseed and soybean under different simulation scenarios (\% change relative to baseline values by 2030). Source: CAPRI model

Figure 12: Production changes for the major country/region traders of a) wheat, b) maize, c) soybean and c) rapeseed in 2030 under different simulation scenarios (\% change relative to baseline values by 2030). Country/Regions: European Union (EU-28), United States (USA), Canada (CAN), Australia and New Zealand (ANZ), Middle East and North Africa (MENA), Sub-Saharan Africa (SSA), 
South East Asia (SEA), Argentina (ARG), Brazil (BRA), Other South and Central America (OSA), China (CHI). Source: CAPRI model

Figure 13: Wheat trade in the European Union in 2030 by trading partner under different simulation scenarios: a) imports and b) exports. Country/Regions: Australia and New Zealand (ANZ), Other Asia (OAS), South East Asia (SEA), India (IND), Other South and Central America (OSA), Canada (CAN), United States (USA), Sub-Saharan Africa (SSA), Middle East and North Africa (MENA), Rest of European Union (REU). Values in thousand tons. Source: CAPRI model.

Figure 14: Feed use in European Union by product in 2030 under different simulation scenarios (absolute change relative to baseline by 2030). Values in thousand tons. Source: CAPRI model........ 52

Figure 15: Visual representation of the group map. Circles represent the variables of the system, colours refer to the nexus sector (blue for water, red for energy, green for agriculture, yellow for climate, pink for socioeconomic aspects, brown for land, grey for environment and black for policies and governance) and size depicts centrality. Solid grey lines depict positive casual relationships while dotted red lines illustrate negative causal relationships. Source: Own elaboration.

Figure 16: Importance of variables in the group fuzzy cognitive mapping according to their centrality, represented as the sum of the outdegree and indegree. Source: Own elaboration.

Figure 17: Visual representation of a subset of the group map. The nine variables with centrality higher than 1 are represented. Grey solid lines for positive and red dotted lines for negative connections. Source: Own elaboration.

Figure 18: Steady state. Source: Own elaboration.

Figure 19: Climate change mitigation scenario simulation (absolute change from steady state). Source: Own elaboration.

Figure 20: Sustainable water management scenario simulation (absolute change from steady state).

Source: Own elaboration.

Figure 21: Sensitivity of irrigated agricultural land (total, cereals and citrus fruits) to scenario drivers when shifting from the reference to the worst-case scenario (left) and to the best-case scenario (right). Results are presented for total irrigated land, cereals and citrus fruits. The total change in irrigated land is decomposed in changes due to total, individual and interaction effects of each driver. The results are presented as \% change from the reference scenario. Source: Own elaboration.

Figure 22: Sensitivity of irrigation water use (total, cereals and citrus fruits) to scenario drivers when shifting from the reference to the worst-case scenario (left) and to the best-case scenario (right). Results are presented for total irrigated land, cereals and citrus fruits. The total change in irrigation water use is decomposed in changes due to total, individual and interaction effects of each driver. The results are presented as \% change from the reference scenario. Source: Own elaboration. 
Figure 23: Sensitivity of income (total, cereals and citrus fruits) to scenario drivers when shifting from the reference to the worst-case scenario (left) and to the best-case scenario (right). The total change in income is decomposed in changes due to total, individual and interaction effects of each driver. The results are presented as \% change from the reference scenario. Source: Own elaboration. 


\section{List of Tables}

Table 1: Scenario characterization to assess climate change impacts on agricultural markets.

Table 2: Scenario framework to conduct the sensitivity analysis of CAPRI-Water results.

Table 3: Individual and group map indices (mean and standard deviation)

Table 4: Results from the reference, worst-case and best-case scenarios for rain-fed land, irrigated land, irrigation water use and income for main crops in Andalusia in 2050. The values are presented in absolute terms for the reference scenario and percentage change from the reference for the worst-case and best-case scenarios. The units are 1000 ha for land, million $\mathrm{m}^{3}$ for water use and million euro for income. 


\section{Acronyms}

\begin{tabular}{|c|c|}
\hline ABM & Agent-Based Model \\
\hline AGMIP & Agricultural Model Intercomparison and Improvement Project \\
\hline ATT & All At Time \\
\hline BN & Bayesian Networks \\
\hline CAP & Common Agricultural Policy \\
\hline CAPRI & Common Agricultural Policy Regional Impact Analysis \\
\hline CEDEX & Centre for Public Works Studies and Experimentation \\
\hline EDGAR & Emissions Database for Global Atmospheric Research \\
\hline EEA & European Environmental Agency \\
\hline ERDF & European Regional Development Fund \\
\hline EU & European Union \\
\hline FAO & Food and Agricultural Organization \\
\hline FSS & Farm Structure Survey \\
\hline FCM & Fuzzy Cognitive Mapping \\
\hline GAINS & Greenhouse gas - Air pollution INteractions and Synergies \\
\hline GCM & Global Circulation Model \\
\hline GHG & Greenhouse Gas \\
\hline GDP & Gross Domestic Product \\
\hline GLOBIOM & Global Biosphere Management Model \\
\hline GTAP & Global Trade Analysis Project \\
\hline IMPACT & International Model for Policy Analysis of Agricultural Commodities and Trade \\
\hline IPCC & Intergovernmental Panel on Climate Change \\
\hline ISI-MIP & Inter-Sectoral Impact Model Intercomparison Project \\
\hline LPJmL & Lund-Potsdam-Jena managed Land Model \\
\hline NGO & Non-Governmental Organisation \\
\hline NUTS & Nomenclature of Territorial Units for Statistics \\
\hline OECD & Organisation for Economic Co-operation and Development \\
\hline
\end{tabular}




\begin{tabular}{|c|c|}
\hline OAT & One At Time \\
\hline RCP & Representative Concentration Pathway \\
\hline RDP & Rural Development Programme \\
\hline SA & Sensitivity Analysis \\
\hline SDG & Sustainable Development Goal \\
\hline SDM & System Dynamic Model \\
\hline SIM4NEXUS & $\begin{array}{l}\text { Sustainable Integrated Management FOR the NEXUS of water-land-food-energy- } \\
\text { climate for a resource-efficient Europe }\end{array}$ \\
\hline SMR & Statutory Management Requirements \\
\hline SSP & Shared Socioeconomic Pathway \\
\hline SUPREMA & SUpport for Policy RElevant Modelling of Agriculture \\
\hline SYNERCAP & $\begin{array}{l}\text { Synergies between agricultural and environmental policies for the sustainability of } \\
\text { Mediterranean agricultural systems }\end{array}$ \\
\hline TRQ & Tariff Rate Quota \\
\hline TRUSTEE & $\begin{array}{l}\text { Towards RUral Synergies and Trade-offs between Economic development and } \\
\text { Ecosystem services }\end{array}$ \\
\hline UAA & Utilised Agricultural Area \\
\hline UN & United Nations \\
\hline UNFCC & United Nations Framework Convention on Climate Change \\
\hline UPM & Universidad Politécnica de Madrid \\
\hline WEF & Water-Energy-Food \\
\hline WEI & Water Exploitation Index \\
\hline WFaS & Water Future and Solutions Initiative \\
\hline WFD & Water Framework Directive \\
\hline WOFOST & World Food Studies \\
\hline
\end{tabular}




\section{Introduction}

\subsection{Research context}

This doctoral research was conducted within the Department of Agricultural Economics, Statistics and Business Management of the School of Agricultural, Food and Biosystems Engineering at the Universidad Politécnica de Madrid (UPM) over the period 2014-2019. The work was funded and developed in the framework of two European projects and one national project coordinated at UPM by Professor Maria Blanco:

- TRUSTEE (Towards RUral Synergies and Trade-offs between Economic development and Ecosystem services) was a project from the Seventh Framework Program of the European Commission (RURAGRI ERA-NET) accomplished during the period 20132017 to disentangle the complex relationships between economic development and ecosystem services at different spatial scales. The project builds on a multidisciplinary approach that involves researchers and experts from different fields (i.e., economists, geographers, agronomists, and ecologists) as well as a range of stakeholders to design sustainable strategies for rural areas.

- SIM4NEXUS (Sustainable Integrated Management FOR the NEXUS of water-landfood-energy-climate for a resource-efficient Europe) is a European Union (EU) Horizon 2020 project funded for the period 2016-2020. The project seeks to close knowledge gaps and to develop innovative methodologies to support decisionmaking in the water-land-food-energy-climate nexus under climate change conditions. Building on stakeholder knowledge and complexity science modelling, SIM4NEXUS develops system dynamic models (SDM) and serious games based on 12 case studies at different scales (global, European, and different national, regional and transboundary cases within Europe) and the combination of stakeholder knowledge and quantitative information from statistics and model projections.

- SYNERCAP (Synergies between agricultural and environmental policies for the sustainability of Mediterranean agricultural systems) is a project from the National Research Programme funded by the Spanish Ministry of Economy and Finance and the European Regional Development Fund (ERDF) performed over the period 20162019. The project attempts to improve understanding on the interrelations between agriculture and the environment to guide the design of sustainability strategies and support policy decision-making, which promotes the sustainability of Mediterranean 
agricultural systems. In particular, SYNERCAP aims to identify the key determining factors of agricultural sustainability as well as develop methodologies for the assessment of the socioeconomic and environmental sustainability of Mediterranean agricultural systems to support decision-making.

Additionally, this research benefited from SUPREMA (SUpport for Policy RElevant Modelling of Agriculture), an EU H2020 coordination and support action being implemented over the period 2018-2020 to support integrated policy impact assessments in the fields of agriculture, environment and trade in Europe by reinforcing and connecting modelling groups.

To complement the work performed at UPM, a three-month research stay was undertaken at University College Dublin (Ireland) within the TRUSTEE project, from September $5^{\text {th }}$ to December $6^{\text {th }} 2016$. The research stay was supervised by Dr James Breen and funded under UPM's grant programme for pre-doctoral research stays ${ }^{1}$.

\subsection{Problem description}

The sustainability of agricultural and food systems is confronted with different challenges that need to be addressed to ensure future food security and environmental preservation. Increasing resource scarcity and climate change might undermine the capacity of agriculture to provide food for the growing population. Crop production is very sensitive to climatic conditions and therefore is extremely exposed to climate change impacts both on crop productivity and water availability. Furthermore, projected socioeconomic development over the coming decades is expected to add more pressure on resources and drive conflicts between the different sectors. Water availability and use influence the food and energy sectors and, simultaneously, are influenced by them. Meanwhile, agricultural and environmental policies often target specific areas and seldom build on holistic approaches that considerer trade-offs and synergies across sectors, leading to policy inconsistencies.

Addressing these challenges points to the need for integrated and harmonised policies that consider cross-sectoral connections within the water-energy-food (WEF) nexus to promote sustainable agriculture and resource use efficiency. This requires involving stakeholders from the different sectors to build consensus and ensure coordination and to promote knowledge

\footnotetext{
${ }^{1}$ Resolución 23 de febrero de 2016 sobre Ayudas para estancias breves en España y en el extranjero para los beneficiarios de los programas predoctorales oficiales de formación de investigadores.
} 
sharing between decision-makers and the research community to frame better informed and evidence-based policies.

\subsection{Research objectives}

The general objective of this PhD thesis is to support policy decision-making that promotes sustainable agricultural development and resource use under climate change. This research aims to broaden knowledge on the interrelations between agriculture and the environment by applying a methodological approach based on the combination of bio-economic modelling, participatory approaches and sensitivity analysis techniques. The scale of analysis ranges from the global and European to the regional level, represented by a case study in Andalusia (Spain).

The specific objectives established to achieve the general objective of this thesis are:

- To assess the economic impacts of climate change on agricultural markets at the global and European Union (EU) levels.

- To analyse the role of trade adjustments as an adaptation strategy to offset climate change effects on crop productivity across the world.

- To understand interdependencies between agriculture, energy and water by applying the WEF nexus approach in the regional case study of Andalusia (Spain).

- To identify the main challenges within the WEF nexus according to stakeholders' perceptions.

- To raise awareness and build consensus for the WEF nexus among the different stakeholders.

- To disentangle key water-related drivers of future agricultural development in Andalusia under climate change.

\subsection{Related publications}

\section{Articles}

Martínez, P., Blanco, M., Van Doorslaer, B., Ramos, F., Ceglar, A. (2017). What role will climate change play in EU agricultural markets? An integrated assessment taking into account carbon fertilisation effects. Spanish Journal of Agricultural Research, 15 (3), doi: $10.5424 / \mathrm{sjar} / 2017153-9899$. 
Martinez, P., Blanco, M., Castro-Campos, B. (2018). The Water-Energy-Food Nexus: A FuzzyCognitive Mapping Approach to Support Nexus-Compliant Policies in Andalusia (Spain). Water, 10(5), 664, doi: 10.3390/w10050664.

Martinez, P. and Blanco, M. Sensitivity of agricultural development to water-related drivers: the case of Andalusia (Spain). Water (Under review)

Castaño, J., Blanco, M., Martinez, P. (2019). Reviewing Counterfactual Analyses to Assess Impacts of EU Rural Development Programmes: What Lessons Can Be Learned from the 2007-2013 Ex-Post Evaluations? Sustainability, 11(4), 1105, doi:10.3390/su11041105.

Blanco, M., Ramos, F., Van Doorslaer, B., Martínez, P., Fumagalli, D., Ceglar, A., Fernández, F.J. (2017). Climate change impacts on EU agriculture: A regionalized perspective taking into account market-driven adjustments. Agricultural Systems, 156: 52-66, doi: 10.1016/j.agsy.2017.05.013.

Martínez, P., Blanco, M., Castaño, J. (2017). Simulador PAC: lecciones del análisis del pago verde. Revista Española de Estudios Agrosociales y Pesqueros, 248.

Castaño, J., Martínez, P., Blanco, M. (2017). ¿Es posible conocer el impacto socioeconómico de los Programas de Desarrollo Rural en España? Agrícola Vergel, 399: 59-62.

\section{Books}

Blanco M., Witzke P., Pérez Domínguez I., Salputra G., Martínez P. (2015). Extension of the CAPRI model with an irrigation sub-module; EUR 27737 EN; Luxembourg: Publications Office of the European Union, 2015, doi: 10.2791/319578.

Blanco M., Witzke P., Barreiro Hurle J., Martinez P., Salputra G., Hristov J. (2018). CAPRI Water 2.0: an upgraded and updated CAPRI water module, EUR 29498 EN, Luxembourg: Publications Office of the European Union, 2015, doi: 10.2760/83691.

\section{Conferences}

Martínez, P., Blanco, M., Van Doorslaer, B., Ramos, F., Stanca, L. What role does climate change play in agricultural market uncertainty? An integrated assessment taking into account market-driven adjustments. International Conference of Agricultural Economists. August 2015, Milan (Italy). 
Martinez, P., Blanco, M. Impact of CAP green payment on Spanish agriculture. X Conference of the Spanish Associations of Agricultural Economists. September 2015, Córdoba (Spain).

Stanca, L., Blanco, M., Martinez, P. Impacts of climate change on agricultural markets: A multiscenario analysis. IV Workshop Remedia, March 2015, Madrid (Spain).

Bubbico, A., Martinez, P., Blanco, M., Breen, J. Impact of CAP green payment on different farming systems: the case of Ireland and Spain. 148 Seminar of the European Association of Agricultural Economists. December 2015, Brussels (Belgium).

Bubbico, A., Martinez, P., Blanco, M., Breen, J. Impact of CAP green payment on different farming systems: the case of Ireland and Spain. Agricultural Economics Society of Ireland Conference, January 2016, Dublin (Irleland).

Castaño, J., Blanco, M., Martínez, P. (2017). La cuantificación ex-post de los impactos de los Programas de Desarrollo Rural 2007-2013: Caso de Andalucía. XI National Conference of Agricultural Economics, September 2017, Orihuela-Elche (Spain).

Castaño, J., Blanco, M., Martínez, P. (2018). Evaluating RDPs: To what extent the counterfactual analysis contributed to improve the evaluation of ex-post impacts?. 162nd EAAE Seminar, The evaluation of new CAP instruments: Lessons learned and the road ahead, April 2018, Budapest (Hungary).

Castro-Campos, B., Martinez, P., Blanco, M. (2018). Understanding policy (in)coherence in the water-energy-food-environment-nexus: The case of Andalusia (Spain). GEWISOLA, Visionen für eine Agrar- und Ernährungspolitik nach 2020“, September 2018, Kiel (Germany).

\subsection{Structure of the thesis}

This document is structured in different chapters that summarise the state of the art, the methodological framework, results, discussion and conclusions of this research.

Chapter 2 presents the state of the art, which includes an overview of the socioeconomic and political context, with expected trends and the main policies in agricultural and food. This section also offers a brief description of the scenario framework currently used by the scientific community in climate change research as well as a literature review on the impacts of climate change in agriculture. This review focuses on climate change effects on crop productivity, agricultural markets and water availability, and their implications for 
international trade and irrigation. As agriculture and food systems are highly interconnected with other sectors, these sections ends with a review of the WEF nexus approach.

Chapter 3 presents the methodology used for this investigation, with the description of the general methodological framework and the tools applied. The bio-economic modelling approach and the different simulation scenarios to explore climate change impacts on agricultural markets are explained in detail. The participatory approach performed and the study region as well as all the data collection and processing used to understand the WEF nexus interdependencies in Andalusia are elaborated in this section. Likewise, the sensitivity analysis conducted to disentangle key water-related drivers of agricultural development in Andalusia is described in this chapter.

Chapter 4 summarises the main results obtained in this research, in particular impacts of climate change on global agricultural production and prices as well as the effects on agricultural production for main traders and the role of trade adjustments. In addition, this section highlights the main interrelations in the WEF nexus in Andalusia according to stakeholder's perceptions and the key water-related drivers for future agricultural development in this region.

Chapter 5 offers the discussion of the results derived from the application of each of the methodologies.

Chapter 6 summarises the main findings and contributions of this research as well as its limitations and the need for further research. 


\section{State of the art}

\subsection{Socioeconomic and political context}

\subsubsection{Agriculture and food systems: current status and future trends}

Agriculture is a major provider of food and revenues in rural areas around the world. The balance between food production and consumption varies broadly across countries, depending on climatic conditions, resource availability and socioeconomic factors. This gives rise to the conditions whereby agricultural and food trade becomes an important instrument to achieve food security. Agri-food trade connects areas with surplus and deficit production, thus improving food availability while enhancing region-specific agricultural competitiveness (Brooks and Matthews, 2015).

The current configuration of agriculture and food markets will need to adapt to global changes. Increased population and economic growth are expected to expand food demand over the coming decades, which would in turn trigger an increase in food production by $60 \%$ in 2050 compare to 2005/2007 (Alexandratos and Bruinsma, 2012). Meanwhile, resource constraints for agricultural production and an increasing competition for resources among sectors might pose threats for food security that might be exacerbated by climate change (Marchal et al., 2012; WEF, 2011).

Increased crop yields and food production during the last decades were substantially driven by the expansion of irrigation. Whereas irrigated agriculture only covers $20 \%$ of the total cultivated land, it contributes to $40 \%$ of global food production (FAO, 2011). However, the global area equipped for irrigation is projected to increase $0.1 \%$ annually up to 2050 , in contrast with the annual increase of 1.6\% experienced globally between 1961 and 2009; this rate difference is mainly due to water scarcity (FAO, 2017). As the largest water user, agricultural water withdrawn accounts for $70 \%$ of the total withdrawals around the globe (FAO, 2017). In Europe, agriculture represents around $40 \%$ of the total water abstraction, amounting to more than $80 \%$ in southern regions (EEA, 2018). In some of these regions, high irrigation water demands combined with irregular rainfall lead to eventual or even persistent water scarcity problems (De Roo et al., 2012).

This is the case for Andalusia, a southern Spanish region with a strong agricultural sector very dependent on irrigation. Andalusian agriculture is a major provider of vegetables to the European markets and global exporter of olive oil (Junta de Andalucía, 2018a). The irrigated 
agriculture provides around $60 \%$ of total value of the regional agricultural production (Massot, 2016) and, at the same time, accounts for around $80 \%$ of total water withdrawals in the region (Junta de Andalucía, 2018c). Climate change is projected to aggravate water stress in Andalusia over the next years through more severe and longer droughts in the region (Roudier et al., 2016) and reductions in runoff that might constrain water availability and agricultural production (Donelly et al., 2017).

\subsubsection{Strategies for agriculture and food towards 2050}

In a context marked by increasing resource scarcity and climate change, the implementation of integrated and harmonised policies is essential to lead the transition towards more sustainable food and agricultural systems. The EU and their Member States are committed to the implementation of the Sustainable Development Goals (SDGs) under the international 2030 Agenda for Sustainable Development (UN, 2015) as well as to the Paris Agreement on Climate Change (UNFCCC, 2015). Furthermore, multiple integrated strategies and frameworks have been established to promote resource use efficiency in the medium and long term in the EU, such as the Bioeconomy Strategy (EC, 2018a), the Circular Economy Package (EC, 2019a), the 2030 Climate and Energy Framework (EC, 2014) and the Low-carbon Economy Roadmap (EC, 2018b).

The transition towards more aligned EU policies is also reflected in the evolution of the traditional sector-specific regulations. The Blueprint to Safeguard Europe's Water Resources over the long term (EC, 2012a) aims to improve implementation and alignment of the EU water policies with other sectoral policies. The Blueprint is based on different comprehensive assessments including the European Environmental Agency (EEA) 2012 State of Water Report (EEA, 2012) and the report from the Commission on the implementation of the Water Framework Directive (WFD) (EC, 2012b). The WFD was developed in 2000 to tackle waterrelated challenges in an integrated manner in the EU, establishing the ambitious objective of reaching the good status of water resources by 2015. Nevertheless, the EEA 2012 State of Water Report indicated that although substantial improvements were made, this target was far from being achieved with only around $50 \%$ of the water bodies in good environmental conditions. Insufficient support for targeted measures, governance failures and knowledge gaps are the reasons behind the delay in meeting this goal. The Blueprint proposes diverse solutions to preserve water resources and confront water scarcity that relies on elaborating consistent EU policies. 
The need for the integration of water objectives within the Common Agricultural Policy (CAP) is acknowledged as a crucial step to enhance sustainable development (ECA, 2014). In recognition of this, the CAP post-2020 integrates targeted climate and environmental objectives to cope with climate change, to promote sustainable development and resource use efficiency and to ensure environmental protection. The new system of conditionality introduces statutory management requirements (SMRs) that link the CAP payments with other EU policies, such as the WFD.

With a focus on Andalusia, the move towards more integrated policies is depicted in the latest policies adopted, which place the region in the forefront of the fight against climate change and the promotion of resource use efficiency in Spain. The Law $8 / 2018^{2}$ of measures against climate change and for a new energy model in Andalusia establishes greenhouse gas (GHG) emissions reduction targets and different instruments to combat climate change and promote energy transition in the region. Within the framework of this law, the Andalusian Action Plan for Climate constitutes the general instrument to tackle climate change, including the elaboration of climate impact assessments and the design and implementation of mitigation and adaptation strategies. In addition, the Circular Bioeconomy Strategy, approved in September 2018, focuses on the agri-food and forestry sectors and builds on crosscutting and multi-sectoral measures to foster bioproducts and bioenergy production for the sustainable use of natural resources in the region (Junta de Andalucia, 2018b).

\subsection{Climate change research: scenario framework}

Climate change impacts on the environment and humanity are highly uncertain as they depend on the climate response to different levels of GHG emissions and also on the capacity of society for adaptation and mitigation. To address this uncertainty, most climate change studies apply scenarios that describe alternative future developments under different assumptions (e.g., socioeconomic, technological, climatic, etc.). The development of a new scenario framework eases the assessment of climate change impacts and mitigation options (Moss et al., 2010).

These scenarios are based on a plausible combination of the Representative Concentration Pathways (RCP) and the Share Socioeconomic Pathways (SSP) (Ebi et al., 2014; Kriegler et al., 2012; van Vuuren et al., 2012, 2014). The RCPs correspond to four different possible

\footnotetext{
${ }^{2}$ Ley $8 / 2018$, de 8 de octubre, de medidas frente al cambio climático y para la transición hacia un nuevo modelo energético en Andalucía.
} 
trajectories of future greenhouse gases concentration expressed by the level of possible radiative forcing values in the year $2100(2.6,4.5,6$ and $8.5 \mathrm{~W} / \mathrm{m} 2)$ (van Vuuren et al., 2011). RCP 2.6 represents a mitigation scenario where radiative forcing is very low, RCP 4.5 and RCP 6 depict medium emission scenarios and RCP 8.5 renders an extreme emission scenario where the radiative forcing is very high (Figure 1 ).
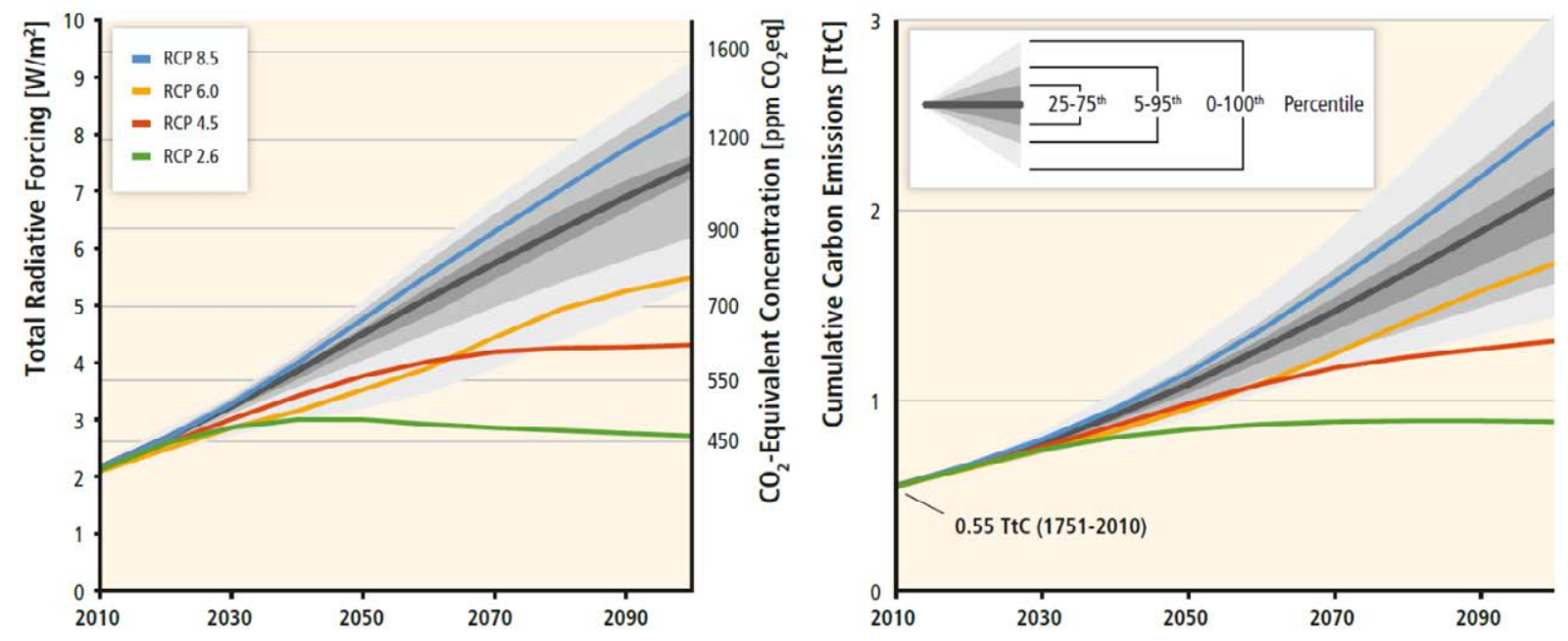

Figure 1: Total radiative forcing (left) and cumulative carbon emissions since 1751 (right) in baseline scenario literature compared to RCP scenarios. Secondary axis in the left panel expresses forcing in CO2eq concentrations. Scenarios are depicted as ranges with median emboldened; shading reflects interquartile range (darkest), 5th - 95th percentile range (lighter), and full extremes (lightest).

Source: IPCC (2014).

RCPs are introduced into climate models to explore climate response to different levels of GHG emissions. Output from these models covers a range of climatic variables (e.g., temperature, precipitation) delivered for each RCP. According to the Intergovernmental Panel on Climate Change (IPCC), global average temperature by 2081-2100 is projected to increase between $0.3^{\circ} \mathrm{C}$ and $1.7^{\circ} \mathrm{C}$ under RCP $2.6,1.1^{\circ} \mathrm{C}$ and $2.6^{\circ} \mathrm{C}$ under RCP $4.5,1.4^{\circ} \mathrm{C}$ and $3.1^{\circ} \mathrm{C}$ under RCP 6.0 and $2.6^{\circ} \mathrm{C}$ and $4.8^{\circ} \mathrm{C}$ under RCP 8.5 compared to 1986-2005 (Figure 2). Furthermore, extreme weather events (e.g., heat waves, droughts) are expected to be more severe and frequent (IPCC, 2013). 
(a) Change in average surface temperature (1986-2005 to 2081-2100)

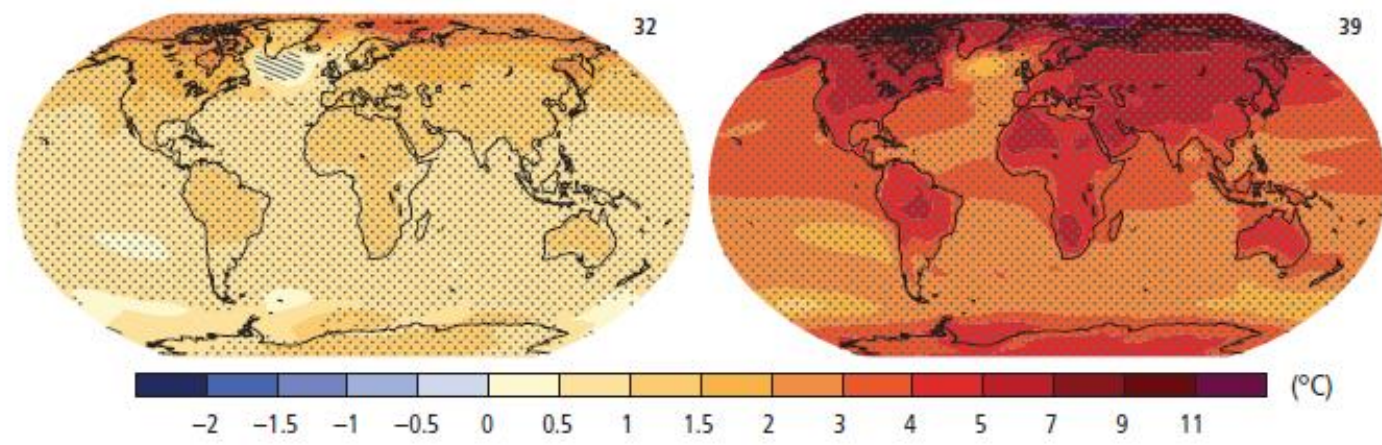

(b) Change in average precipitation (1986-2005 to 2081-2100)

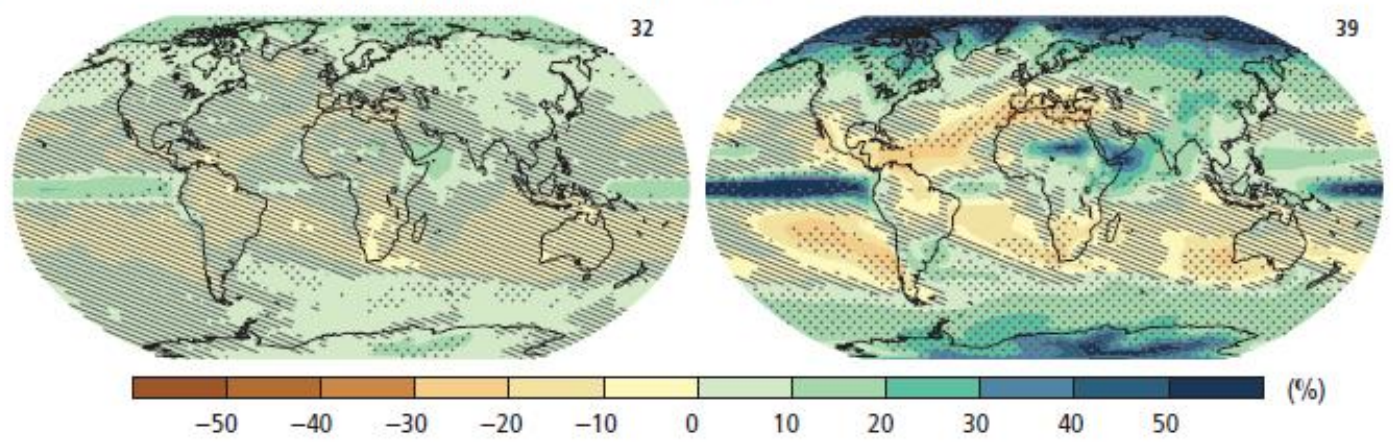

Figure 2: Projected changes in average surface temperature (a) and average precipitation (b) for 20812100 relative to 1986-2005 under the RCP 2.6 (left) and RCP 8.5 (right) scenarios from multi-model mean projections.

Source: IPCC (2013).

The SSPs describe plausible future socioeconomic pathways based on different factors determining challenges to mitigation and adaptation: demographics, human development, the economy and lifestyle, policies and institutions, technology and the environment. The SSPS comprise narratives and quantified drivers of future societal development, under the assumption of no climate change and no climate policies. As shown in Figure 3, five narratives describe the likely combinations of high or low challenges to adaptation and mitigation (O'Neill et al., 2014, 2017):

- SSP 1 - Sustainability

The pathway reflects a more sustainable world where human well-being becomes more important than the rapid economic growth, driven by strong environmental commitments and improved resource use efficiency. Investments in environmental technology and improvements in human well-being and governance would lead to low challenges to mitigation and adaptation. 
- SSP 2 - Middle of the road

Consistent with historical trends, this pathway depicts a world where economic development and technological improvements follow observed patterns. Population moderately increases and resource use slightly decreases. As a result, this pathway addresses moderate challenges to mitigation and adaptation.

- SSP 3-Regional rivalry

The pathway reflects a world that is characterised by increasing divergences across regions. Economic development and technological change grow slowly and resource use is intensive. Population growth is slow in developed regions and rapid in developing countries. This, in combination with a lack of international cooperation, triggers high challenges to mitigation and adaptation.

- SSP 4-Inequality

This pathway is defined by increasing concentration of power in small political and business groups and growing disparities between developed and developing countries. Technology development is high in the high-tech economy and sectors. Energy sources are diversified with investments in both conventional and also lowcarbon energy sources. Consequently, this world would face low challenges to mitigation and high challenges to adaptation.

- SSP 5 - Fossil-fuelled development

This pathway defines a future world driven by an industrialised and fossil fueldependent economy, competitive markets, rapid technological progress and significant social investments. Environmental impacts are successfully tackled at the local level, disregarding global effects because of the trade-offs with economic growth. This would result in a world with high challenges to mitigation and low challenges to adaptation. 


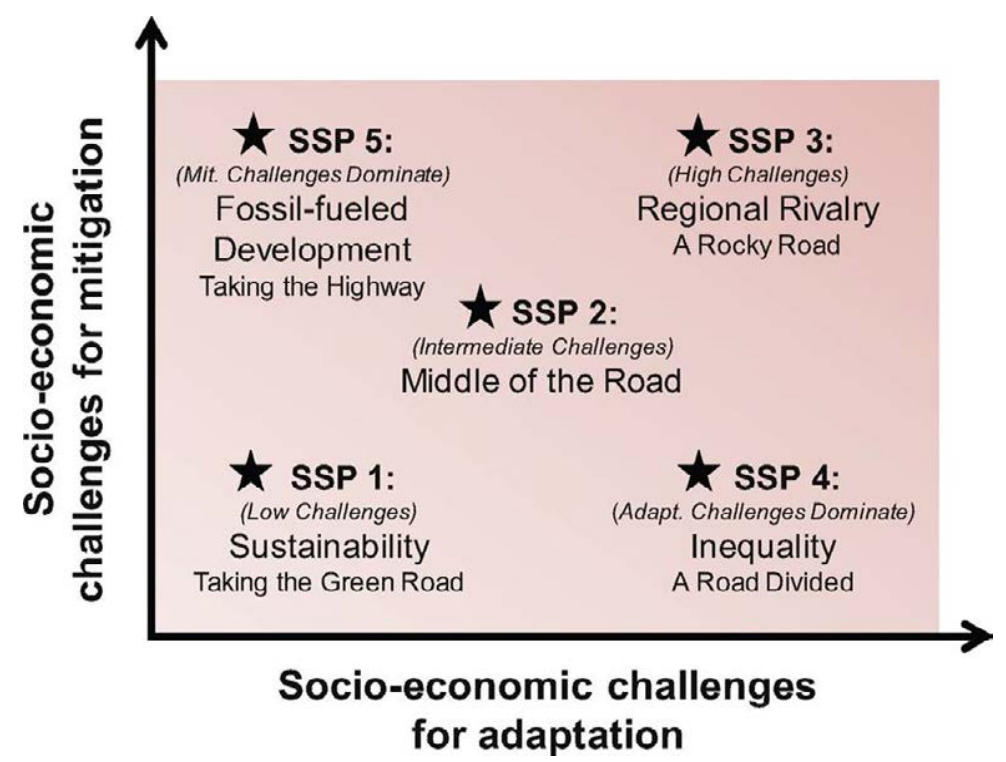

Figure 3: SSPs challenge to mitigation and adaptation.

Source: O'Neill et al. (2014).

\subsection{Impacts of climate change on agriculture}

\subsubsection{Climate-induced changes in crop yields}

Agriculture is one of the most sensitive sectors to climate variations since production largely relies on climatic conditions (Adams et al., 1998; Gornall et al., 2010; Lobell and Field, 2007). Climate change affects crop yields and, therefore, agricultural production and prices. The extent of these impacts is surrounded by several uncertainties linked to the climate evolution in the next decades, future socioeconomic development and the effects of rising $\mathrm{CO}_{2}$ atmospheric concentration on crop physiology and productivity, referred to as carbon fertilisation effect.

Carbon fertilisation effects differ among species depending on the metabolic pathway performed to fix carbon during the photosynthesis process ( $\mathrm{C} 3$ and $\mathrm{C} 4$ ). The enzyme involved in the $\mathrm{CO}_{2}$ fixation (Rubisco) is not $\mathrm{CO}_{2}$-saturated in $\mathrm{C} 3$ plants (e.g., wheat, soya, rapeseed) while is saturated in C4 plants (e.g., maize, sorghum, sugarcane). Therefore, increasing atmospheric $\mathrm{CO}_{2}$ concentration results in higher $\mathrm{CO}_{2}$ fixation and biomass accumulation in $\mathrm{C} 3$ plants, but has no additional effect on crop physiology in C4 plants. The consequences of carbon fertilisation on crop yields have been extensively studied (Ainsworth \& Long, 2005; Gifford, 2004; Tubiello et al., 2007; Wang et al. 2012). Whilst most studies concluded that carbon fertilisation has a positive effect on crop yields under idealised conditions, the real effect on crop productivity in the field remains an issue for further research as little is known 
about the interaction of elevated $\mathrm{CO}_{2}$ concentration with other factors such as crop diseases or nutrient availability.

Understanding the responses of the agricultural sector to alternative scenarios accounting for these uncertainties is vital to evaluate the potential influence of climate change on the future development of agricultural markets. Without considering carbon fertilisation effects, a number of studies predicted climate-induced changes in crop productivity by 2050. Müller and Robertson (2014) estimated significant global declines in crop yields under RCP 8.5 that range from $9.9 \%$ to $37.6 \%$ for major crops (i.e., wheat, maize, rice, soybean).

Considering uncertainties linked to carbon fertilisation effects, several authors observed different effects on crop yields in simulations with and without carbon fertilisation. Deryng et al. (2014) predicted strong decreases in maize, spring wheat and soybean yields under RCP 8.5 and extreme heat stress by 2080, which are mitigated in part for spring wheat and soybean when considering carbon fertilisation effects. Rosenzweig et al. (2014) highlighted that climate-induced yield changes for major crops under RCP 8.5 vary substantially between scenarios with and without carbon fertilisation effects, especially for C3 crops. Disregarding $\mathrm{CO} 2$ effects leads to more negative effects on crop yields, denoting the need for further research in this important field.

Besides relying on crop type and carbon fertilisation effects, the impact of climate change on yields is also region-specific and thereby varies across the world. Spatial patterns of crop yield changes have been explored in different investigations. Rosenzweig et al. (2014) projected yield increases for maize and wheat in high latitudes, whereas yield declines are expected in low latitudes. However, Müller et al. (2014) observed notable yield drops for maize all around the world, high-latitudes included.

Figure 4 summarises average crop yield percentage changes per decade based on a systematic review of country-specific, multi-countries and global studies elaborated by the IPCC (IPCC, 2013). Estimates are presented by region (temperate vs. tropical), modelling approach (process-based vs. statistical), carbon fertilisation effects, and for four major crop (i.e., wheat, soybean, rice and maize). Results from this meta-analysis indicate marked differences in climate-induced yield changes across crops, which particularly affect wheat and maize. While studies considering carbon fertilisation effects are fewer than those without accounting for these effects, results show significant differences in yield changes due to carbon fertilisation. 
Looking at spatial patterns, climate change impacts on yield are expected to be less severe in high-latitude regions.

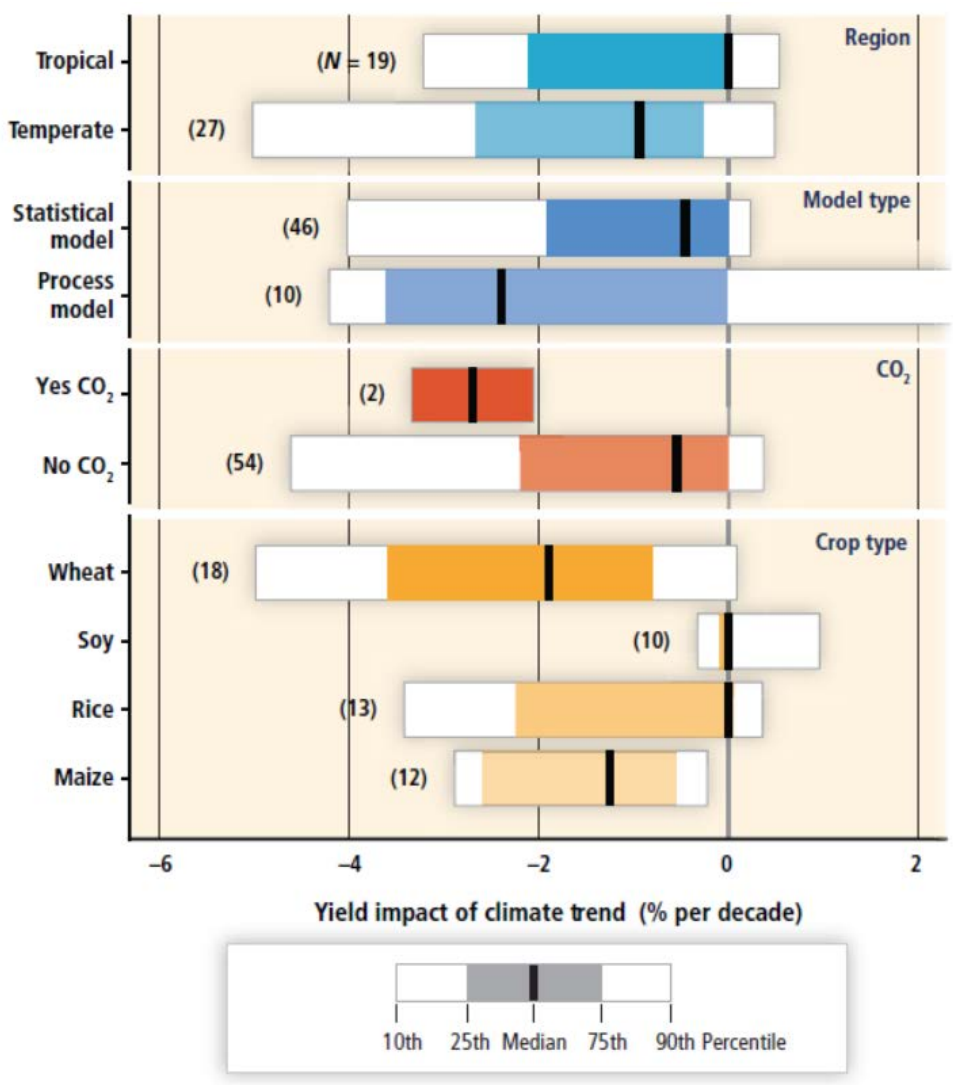

Figure 4: Impacts of climate change on average yields based on a literature review categorised by region (temperate vs. tropical regions), modelling approach (process-based vs. statistical), carbon fertilisation effects, and crops. Numbers in parentheses depicts the number of estimates. Value in percentage change per decade. Source: IPCC (2013).

\subsubsection{Climate change impacts on agricultural markets: the role of trade}

Considering not only biophysical effects but also economic implications of climate change in agriculture is vital to encompass the entire range of potential impacts and adaptation strategies. Different studies predicted increasing agricultural prices up to 2050 derived from socioeconomic development and negative impacts of climate change in crop productivity across the world. Nonetheless, impacts on crop yields would be globally diffused through interregional adjustments in agricultural markets, highlighting the crucial role of trade to counterbalance climate change impacts on crop productivity (Calzadilla et al., 2013; Baldos and Hertel, 2015; Fernandez and Blanco, 2015; Nelson et al., 2010; Reilly and Hohmann, 1993; Tobey et al., 1992). 
Building on the new climate change scenario framework, most economic impact assessments of climate change on agriculture effects concentrate on analysing uncertainties related to economic models (Delincé et al., 2015; Nelson et al., 2014; Von Lampe et al., 2014) or to different plausible combinations of socioeconomic and emissions scenarios (Wiebe et al., 2015), while omitting crop response to rising $\mathrm{CO}_{2}$ atmospheric concentration.

Looking into studies that examine carbon fertilisation effects, Blanco et al. (2017) were among the first to assess economic impacts of climate change on agriculture considering carbon fertilisation. Based on the Common Agricultural Policy Regional Impact Analysis model (CAPRI), this work analysed climate change impacts at subnational level within the EU, while considering market feedback, under different scenarios differing on climate projections and the degree of carbon fertilisation in 2030. The authors concluded that crop price effects lessen global climate change impacts on crop production and highlighted uneven effects across regions and related trade adjustments, suggesting that a multi-scale approach is important for a comprehensive assessment of climate impacts.

\subsubsection{Climate change impacts on water resources: implications for irrigation}

Crop production is extremely sensitive not only to climate change impacts on crop productivity but also on water availability (Byers et al., 2018; Ciscar et al., 2018). The interface between agriculture and water is likely to become more important under climate change conditions, as evidenced by different studies that anticipate reductions in runoff that might constrain water availability for agriculture worldwide and at the EU level (Betts et al. 2018; Bisselink et al. 2018; Donelly et al. 2017).

Simultaneously, impacts on irrigation water demand are expected due to changes in crop evapotranspiration and precipitation patterns. Konzmann et al. (2013) estimated increases in water demand for irrigation in most regions across the world except southern Asia, where precipitation is expected to increase. When carbon fertilisation is considered, their results showed an average decline of around $17 \%$ in global irrigation water demand that will affect between $30-50 \%$ of the total irrigated land in the world. Nonetheless, this global figure hides notable regional differences. For instance, water demand for irrigation in southern Europe is projected to increase more than $20 \%$. In line with this results, Elliot et al. (2014) anticipated an overall increase in global irrigation demand when simulations are run without $\mathrm{CO}_{2}$ effects, whereas an average decrease from $8 \%$ to $15 \%$ projected by end of the century if $\mathrm{CO}_{2}$ effects are considered. Positive effects of carbon fertilisation on water use efficiency, combined with 
shorter cropping cycles, partially offset effects of rising potential crop evapotranspiration and reductions in rainfall. Nevertheless, limitations in water availability in some agricultural areas highly dependent on irrigation could entail the conversion of 20-60 million hectare from irrigated to rain-fed land, with significant implications for agricultural productivity.

Climate induced impacts on irrigated crop productivity have been explored in different studies. Zhao et al. (2015) assessed climate change impacts on irrigation requirements and yields for a set of crops (i.e., winter wheat, winter barley, rapeseed, maize, potato, and sugar beet) in Europe. They concluded that increases in yields are expected in middle and northern European regions, while decreases are projected in Mediterranean countries. In addition, a number of studies have examined different irrigation strategies to address potential negative effects on crop productivity in the Mediterranean region. For instance, Fader et al. (2016) simulated alternative scenarios that depict different efficiencies from irrigation and conveyance systems, concluding that water savings around $35 \%$ could be achieved with the introduction of more efficient irrigation systems. In addition, the authors highlighted that gross irrigation water requirements would be driven by irrigation efficiency, growing demand for food and water, and climate change impacts, with the first two being the most determinant factors.

These studies provide a valuable insight into the water-food interlinkages but they disregard market effects. Incorporating water issues in economic models is particularly challenging because projections for water parameters are either highly uncertain, difficult to access or scarce. Hence, despite the importance of water as major driver for agricultural production, few studies analyse the impacts of climate change on agricultural and food markets considering the water dimension. Examples of these assessments include that by Sauer et al. (2010), which globally assessed land and water use under increasing food demand driven by population growth and economic development using the Global Biosphere Management (GLOBIOM) model. Their results highlighted a notable expansion in irrigated land and an increase in irrigation water use, with an average decline in water use per hectare. This confirms the need for comprehensive assessments that integrate the role of irrigation to promote food security and human well-being.

Sulser et al. (2010) analysed the interplay between green and blue water for food production under different policy scenarios, which depict different levels of technological development and investments in agriculture, in the Ganges and Nile river basins using the International Model for Policy Analysis of Agricultural Commodities and Trade (IMPACT) model. Whereas 
investments should target both irrigated and rain-fed crop productivity and enhanced management of precipitation on irrigated areas in the Ganges basin, efforts need to be concentrated on the expansion of irrigated land and the enhancement of rain-fed crop yields in the Nile basin. This reveals the importance of considering both green and blue water in the assessments to improve agricultural production under increasing water scarcity and to improve the livelihood of populations living in poverty conditions.

Liu et al. (2014) explored the impacts of future changes in water availability for irrigation worldwide on crop production, food prices and trade based on simulations with the GTAPBIO-W model. Irrigation availability in 2030 is projected to decrease between $30-60 \%$ in different major rivers basins in the world, yet this does not always entail diminishing total regional agricultural output. Crop production depends on global prices that can trigger regional adjustment in crop land to enhance crop output. Furthermore, regional changes in irrigation enhance international trade and foster geographical adjustments. These findings demonstrate that exploring the water-food nexus cannot be limited to assessing the effects of irrigation changes on crop productivity and agricultural land. A comprehensive assessment requires the consideration of the role of global markets to counterbalance negative effects of reduced water availability in regional crop production.

More recently, Blanco et al. $(2015,2018)$ have explored the water-food nexus with a focus on the EU using the CAPRI-Water model. These studies investigated potential effects of climate change and water availability, as well as policy instruments such as water pricing or irrigation efficiency improvement, on agriculture at the Nomenclature of Territorial Units for Statistics (NUTS) 2 level within the EU. The results showed an overall negative effect of climate change on crop yields across crops and regions, which are more negative for rain-fed than for irrigated crops. Furthermore, the authors concluded that increasing irrigation water price prompts strong adverse effects on irrigation shares, which particularly affects southern and eastern European regions. Improvements in irrigation efficiency attenuate the decrease in irrigated area and trigger a significant decrease in total water use. Therefore, irrigation plays a role as an adaptation strategy to attenuate the negative effects on climate change and water scarcity in crop productivity.

\subsection{Sustainable resource management: Water-Energy-Food (WEF) nexus}

Agricultural and food systems will be challenged not only by climate change. Expected socioeconomic development over the coming decades is likely to add more pressure on 
resources and drive conflicts between the different sectors (FAO, 2014; Bhaduri et al., 2015). Water availability and use influence the food and energy sectors and, simultaneously, are influenced by them. Addressing these cross-sectoral connections is crucial to promote efficiency in the use of resources and ensure a more sustainable future.

The 2008 World Economic Forum Annual Meeting drew attention to linkages between water and economic growth, introducing the WEF nexus concept and highlighting the need to identify trade-offs and synergies across sectors to promote resource use efficiency. The Bonn 2011 Nexus Conference constituted the first global initiative on the WEF nexus, where the need for a nexus approach in decision-making was reinforced and further explored. Challenges such as population growth, economic development, increasing urbanisation, constrained resource availability, and climate change threaten global food security and dampen development opportunities to enhance human well-being around the world (Hoff, 2011). Meanwhile, policies related to the WEF nexus often focus on specific sectors and rarely build on systemic approaches, resulting in policy incoherence among sectors (Allouche et al. 2019; Lindberg and Leflaive, 2015). The WEF nexus can contribute to tackling these challenges by applying a cross-sectoral and multi-stakeholder approach that enhances synergies and reduce conflicts while promoting policy coherence across sectors and scales (Hoff, 2011; WEF, 2011).

The international community increasingly perceives the WEF nexus as an overarching concept to address these complex and interconnected resource management challenges (FAO, 2014; Hoff, 2011; OECD, 2017). Since the Bonn conference, multiple initiatives have continued attracting attention on the WEF nexus and bringing together researchers and policy makers to encourage discussion and promote the transition from isolated sectoral thinking to a nexus approach. Examples of such actions include the World Economic Forum in 2011 and the Organisation for Economic Co-operation and Development (OECD) Global Forum on Environment in 2014. At the same time, numerous research actions have been focused on the nexus all around the world (Albrecht et al., 2018; Endo et al., 2017).

Understanding the interlinkages in the WEF nexus is acknowledged as a crucial step to improve knowledge, to build capacities and to promote action in order to improve the natural environment upon which economic development and social well-being depend. To that end, increasing efforts are devoted to developing conceptual and methodological frameworks to describe the interlinkages in the nexus as well as to guide decision-makers in applying the WEF nexus approach at different scales. At the global level, the Food and Agriculture Organization (FAO) integrates the WEF approach within its vision of sustainable food and agriculture to help 
eradicate hunger and alleviate poverty, while managing natural resources in a sustainable way (Figure 5).

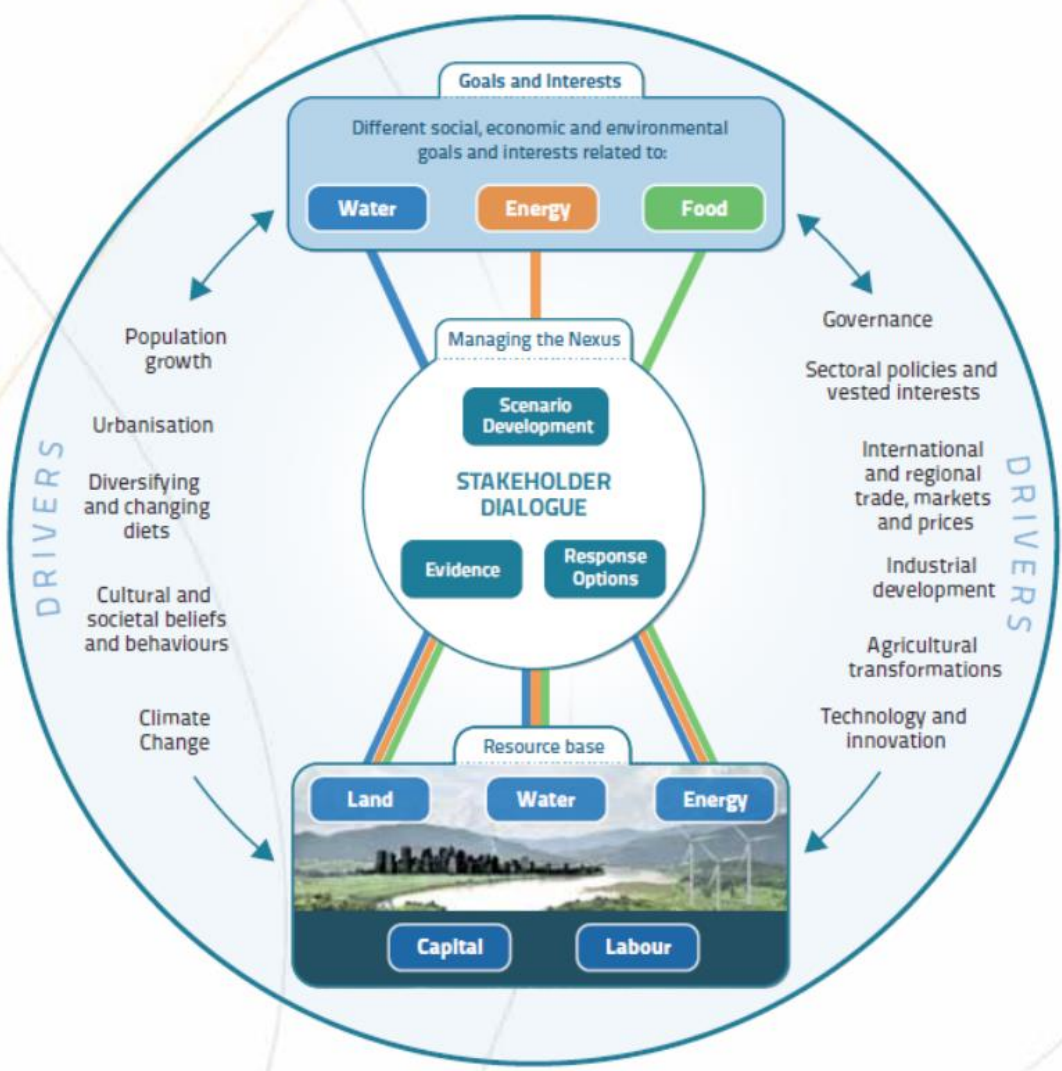

Figure 5: FAO's vision on the WEF nexus.

Source: FAO (2014)

Since targeted actions are required to address local challenges, examples also exist of specific applications of WEF nexus assessments at a more local level. Smajgl and Ward (2013) offered a cross-sectoral assessment of different development strategies in the Mekong river region. De Strasser et al. (2016) proposed a methodology based on the WEF nexus perspective to promote resource efficiency and governance in transboundary river basins, by identifying trade-offs and synergies across sectors and among countries. Mayor et al. (2015) presented a framework that looks at conflicts and interconnections within the WEF nexus in the Duero river basins (Spain). Among the most significant interdependencies, the growing energy cost for irrigated agriculture due to irrigation systems modernisation emerges as a major concern for sustainable agricultural development.

Navigating the nexus entails framing integrated policies that consider the intricate and dynamic nature of the interconnections between sectors. Policy coherence in the nexus is crucial to anticipate unexpected effects and build more resilient and sustainable systems. This 
requires involving stakeholders from the different sectors to raise awareness, build consensus and improve coordination (WEF, 2011). Effective cooperation is required both among sectors (horizontal coherence) and across levels of government (vertical coherence) to ensure consistency and harmonisation of the nexus policies. Additionally, knowledge sharing between decision-makers and the scientific community can also help to design better informed and evidence-based policies (Lindberg and Leflaive, 2015). 


\section{Methodology}

\subsection{Methodological framework}

The methodological framework applied in this research builds on the combination of bioeconomic modelling, participatory approaches and sensitivity analysis techniques (Figure 6). The scale of the analysis ranges from the global and EU to the regional level with a case study in Andalusia (Spain).

The bio-economic modelling approach builds on the CAPRI model to assess climate change impacts on agri-food markets at global and EU levels and investigate market-driven adaptation strategies under different scenarios over the horizon 2030.

Addressing global climate change impacts requires implementing policies at a more local level that account for region-specific effects and cross-sectoral connections. In recognition of this, the scope of the analysis is extended to the water and energy sectors to explore the WEF nexus, while at the same time the scale is reduced to the region of Andalusia. This region has a significant agricultural potential strongly linked to irrigation and highly dependent on energy. The region faces water scarcity problems that might be aggravated under climate change, with important consequences for the sustainable economic development. At the same time, the regional government is strongly committed to tackle climate change and enhance sustainable water management and agriculture through the implementation of diverse laws and strategies. These reasons convert Andalusia in a valuable case study to investigate the WEF nexus and support evidence-based decision-making.

Providing assessments relevant for policy-making needs to consider all stakeholders perceptions and concerns. Through a participatory approach based on Fuzzy Cognitive Mapping (FCM), regional stakeholders are engaged to identify main challenges in the WEF nexus in Andalusia and to contribute to raise awareness and build consensus.

Results from this stakeholder consultation process provide also the foundation to disentangling key water-related drivers in agricultural development in Andalusia over the temporal horizon of 2050. This analysis draws on CAPRI-Water, an upgraded version of the CAPRI model that accounts for water use in agriculture, and sensitivity analysis with finite changes. 


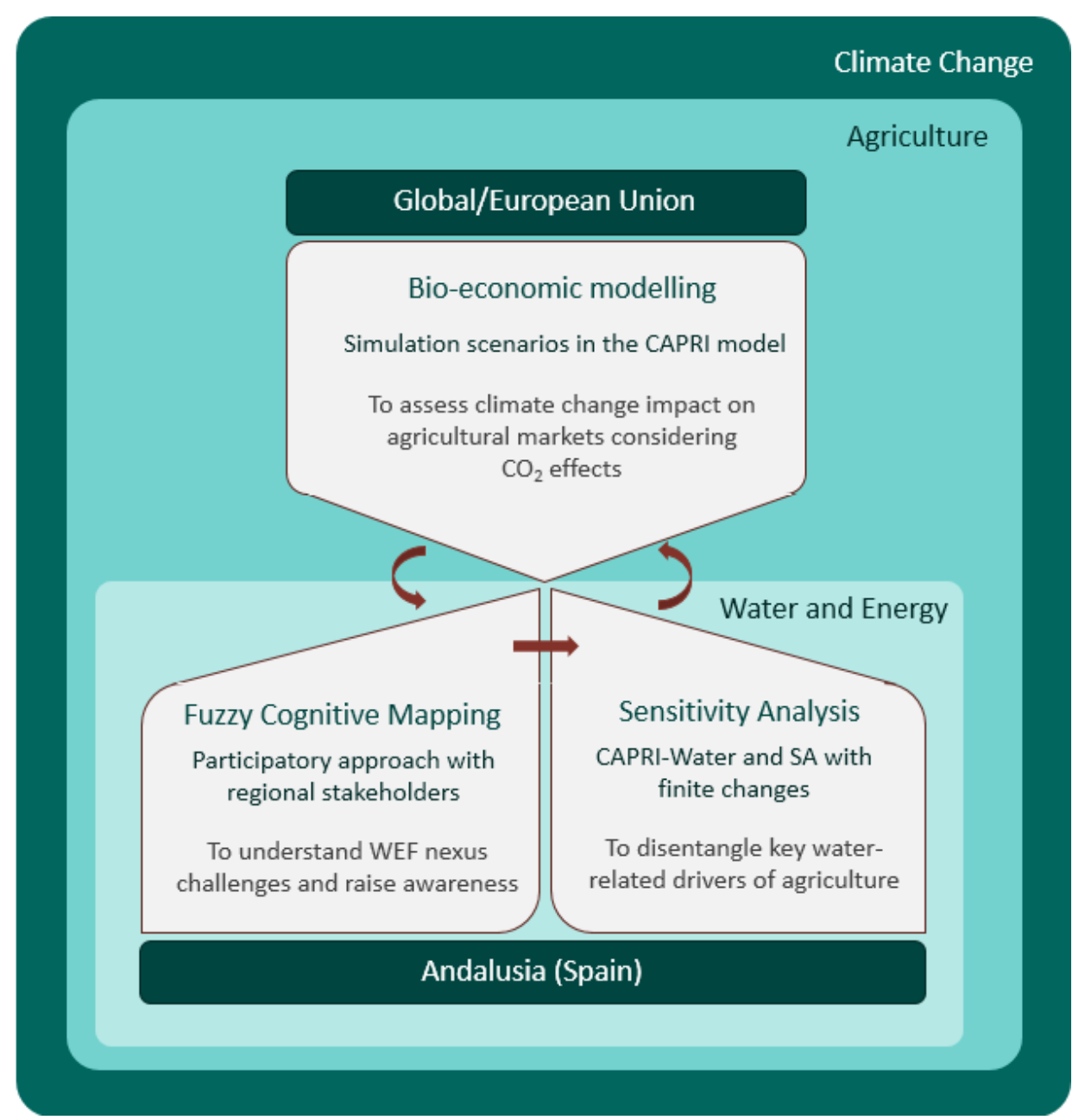

Figure 6: Methodological framework of the thesis research.

\section{CAPRI model overview}

CAPRI is a well-established global agro-economic model developed for policy impact assessment purposes with a focus on the EU (Britz and Witzke, 2014). The comparative-static structure of the model enables the evaluation of agricultural, environmental and trade policies by comparison of policy scenarios against a baseline or reference scenario over a future temporal horizon (e.g., 2030, 2050). CAPRI draws upon a complete and consistent database that integrates information from different official data sources (e.g., EUROSTAT, FAOSTAT) and feeds it into two core modules: the supply module and the market module.

The supply module comprises regional agricultural nonlinear programming models for EU-28, Norway, Turkey and Western Balkans, which represent at length farming decisions at subnational level (NUTS 2 level or farm type level) by means of mathematical programming. The module captures a broad range of interactions between agricultural activities and the environment. Hence, the module computes irrigated and livestock water use at the NUTS 2 
level in the CAPRI water module within the supply module (Blanco et al. 2015, Blanco et al., 2018). Furthermore, agricultural GHG emissions per activity are computed endogenously following the IPCC guidelines (Leip et al., 2010; Pérez Dominguez, 2006). Additionally, the module integrates endogenous GHG emissions mitigation technologies based on the Greenhouse gas - Air pollution INteractions and Synergies (GAINS) database (Pérez Dominguez et al., 2016; Van Doorslaer et al., 2015).

The market module is a static, deterministic, partial, spatial model with global coverage, depicting about 60 commodities (primary and secondary agricultural products) and 40 trade blocks. It simulates supply, demand, and price changes in global markets considering bilateral trade flows as well as trade policies (e.g., Tariff Rate Quotas (TRQs), intervention stock changes and subsidised exports). Demand and supply quantities are endogenous and driven by behavioural functions depending on endogenous prices. Prices in different regions are linked via a price transmission function, whereas prices in different markets in any one region are linked via cross-price terms in the behavioural functions. Agricultural GHG emissions for nonEU regions are estimated per product for marketable agricultural commodities based on data from FAOSTAT and the Emissions Database for Global Atmospheric Research (EDGAR) (Pérez Dominguez, 2006; Pérez Dominguez et al., 2012).

The CAPRI baseline depicts the projected agricultural situation under status quo policy setting. The baseline draws on the medium-term outlook for EU agricultural markets and income (EC, 2018c) for mid-term projections and other model projections for the long run (e.g., GLOBIOM, IMPACT). The baseline represents in detail the CAP 2014-2020 as well as commitments under the Uruguay Round Agreement on Agriculture.

\section{Participatory modelling approaches}

Participatory modelling with stakeholders has been increasingly applied over the last years to share knowledge, improve understanding of a system and overcome governance obstacles. Voinov and Bousquet (2010) reviewed the state of the art on stakeholder engagement and discussed the main methodologies applied to engage stakeholders in resource and environmental modelling, among them Bayesian networks (BN) (Barton et al. 2012), agentbased models (ABM) (Bousquet et al., 1999) and fuzzy cognitive mapping (FCM) (Kosko, 1986). In a recent paper, Voinov et al. (2016) reviewed the progress made in applying participatory modelling in environmental decision-making and stressed the need to develop comprehensive guidelines to select the best-suited methodology-among the wide range of existing tools and 
techniques-depending on the modelling objectives as well as the participants involved. In this regard, several frameworks have been proposed to support the process and to achieve the successful participation of stakeholders in conceptual modelling by, among others, Argent et al. (2016), Basco-Carrera et al. (2017), Gray et al. (2018) and Halbe et al. (2018).

Among the participatory modelling methodologies, FCM focuses on knowledge sharing and stakeholder involvement (Gray et al., 2015) and allows for interactions and feedbacks between variables (while other methodologies such as $\mathrm{BN}$ are based on unidirectional connections). FCM has proven to be very useful in a variety of domains, as emphasized by Papageorgiou and Salmeron (2013) in a review of recent applications of this approach. In the environmental field, FCMs have been used to support watershed ecosystems management (Bosma et al., 2017; Hobbs et al., 2012; Kafetzis et al., 2010; Solana-Gutiérrez et al., 2013; Vasslides and Jensen, 2016), landscape modelling (Van der Sluis et al., 2018; Wildenberd et al., 2010), forest management (Kok, 2009), farming systems analysis (Vanwindekens et al., 2013), fisheries management (Gray et al., 2012), bioethanol production from biowaste (Koti et al., 2018), and intrusion of mining into landscapes (Misthos et al., 2017). FCMs have been also applied to assess climate change impacts and effects of adaptation measures (Reckien, 2014; Olazabal et al., 2018). Nevertheless, examples of the implementation of FCMs to the WEF nexus are scarce (Ziv et al., 2018).

\section{Sensitivity analysis techniques}

Sensitivity analysis techniques assign uncertainty in model output to model input, enabling one to identify key drivers of model results (Saltelli, 2002). Sensitivity analysis approaches are typically divided into local and global methods. Local methods investigate variations in model results related to shifts of an input factor around a given point, while global methods explore the entire range of variability of the input factors. Additionally, sensitive analysis tools can be classified into "One at time" (OAT) and "All at time" (ATT) methods, according to the variation of one input factor at a time or all the input factors at once to analyse output variations (Borgonovo and Plischke, 2016; Norton, 2015; Saltelli et al., 2008; Pianosi et al., 2016). Advantages and disadvantages of the different SA methods have been widely discussed in the literature (Borgonovo and Plischke, 2016; Saltelli and Annoni, 2010; Saltelli et al., 2019). 


\subsection{Impacts of climate change in agricultural markets: Bio-economic modelling approach}

\subsubsection{Bio-economic modelling approach}

The modelling approach employed in this analysis is based on a combination of biophysical and economic models to assess the impacts of climate change on agricultural markets. Biophysical models simulate climate change effects on crop productivity, incorporating climate projections as well as the degree of carbon fertilisation. The projections on future climate are provided by Global Circulation Models (GCMs) based upon RCPs. Climate-induced crop yield changes derived from biophysical models are incorporated into economic models to simulate impacts on production, prices and trade flows based on SSPs (Figure 7). In this study, we used the agro-economic model CAPRI to assess the impacts of climate change on global and EU-wide agri-food markets in 2030. We refrain from using longer-term projections due to their high uncertainty with respect to macroeconomic and agricultural conditions.

Accordingly to the spatial resolution of the CAPRI model, we used more detailed yield projections for EU regions than for the rest of the world. Thus, for EU regions we simulated climate change impacts on productivity using the biophysical model WOFOST (World Food Studies) (Boogaard et al., 2014; Van Diepen et al., 1989). EU crop yield changes were simulated for the year 2030 at a $25 \mathrm{~km}$ grid resolution for nine of the most produced crops (wheat, maize, barley, rye, field beans, rapeseed, sunflower, sugar beet and potato). The results of the simulations were aggregated to a regional level (NUTS 2) using regional statistics for cultivated crop areas (Blanco et al., 2017).

For non-EU countries, we used crop yield projections from the Inter-Sectoral Impact Model Intercomparision Project (ISI-MIP) modelling initiative. In particular, yield projections from the Lund-Potsdam-Jena managed Land (LPJmL) model (Bondeau et al., 2007) were used for the year 2030. These projections are available for the following seven crops: wheat, maize, rice, rapeseed, soybean, sugar beet and sugar cane. Statistics on crop areas were used to aggregate grid-level data to the spatial units of the global CAPRI model (trade blocs).

From the results of these biophysical models, we derived crop yield changes (between 2010 and 2030) for a distinct number of crops, depending on the crop model as mentioned above. To consider all crops within the CAPRI model, yield changes obtained from WOFOST or LPJmL were assigned to those crops not included in these models, based on similarities among crops or crop groups and considering the type of photosynthesis (C3 and C4), similar to previous studies (Müller and Robertson, 2014). 
These crop yield changes were introduced into CAPRI as exogenous productivity shifters. In the case of EU regions, yield changes were explicitly incorporated into the supply module within the regional programming models at the NUTS 2 level, whilst for non-EU regions changes were incorporated into the market module within the supply functions defined for each trade block. CAPRI then provided simulated results about cropland allocation, yields, production, prices and trade for the roughly 60 commodities covered by the model.

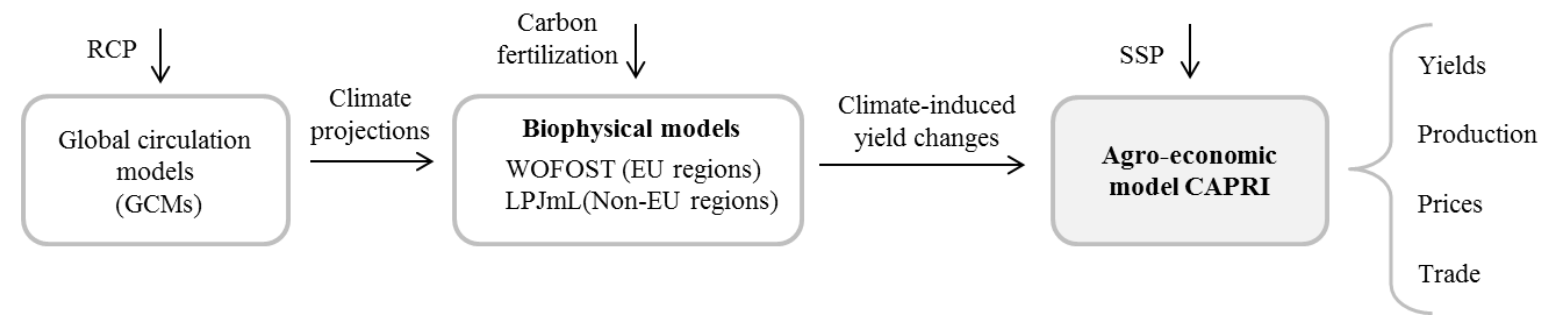

Figure 7: Bio-economic modelling approach. RCP (Representative Concentration Pathway); SSP (Share Socioeconomic Pathway); CAPRI (Common Agricultural Policy Regional Impact Analysis Model).

\subsubsection{Definition of simulation scenarios}

Different scenarios were defined to analyse the variability of future agricultural market developments due to uncertainty about the impacts of climate change on crop yields. All scenarios analysed were based on the SSP2, to consider a storyline consistent with the socioeconomic developments observed in recent decades.

The baseline scenario in 2030 assumes no climate change (current climate continues in 2030) and takes into account the likely developments in agricultural markets between 2010 and 2030 based on SSP2 socio-economic drivers (on a global to regional scale). For a detailed description of the baseline, see Frank et al. (2014).

The simulation scenarios incorporate crop yield shocks according to different climate projections and carbon fertilisation effects. Both biophysical models (WOFOST and LPJmL) derived yield changes results using the scenarios presented in Table 1 and explained below:

1. Emission scenarios: two RCPs were selected in the development of this analysis, the RCP 4.5 (targeting stabilization at $4.5 \mathrm{~W} / \mathrm{m} 2$ after 2100) and the RCP 8.5 (with a radiative forcing of $8.5 \mathrm{~W} / \mathrm{m} 2$ by 2100 and a subsequent upward trend). The RCP 4.5 was chosen as we considered this pathway to be the most likely level by the year 2030, whilst the RCP 8.5 represented an extreme pathway. 
2. Climate projections: two Global Circulation Models (GCMs) were used for each RCP, HadGEM2-ES (Hadley Centre, UK Meteorological Office) and IPSL-CM5A-LR (Institute Pierre-Simon Laplace, France). These two GCMs were selected because they provide data for the type of biophysical models employed in this study. Also, using more than one GCM allows for taking into account uncertainty linked to future climate projections, especially with regard to precipitation patterns at the regional level (IPCC, 2013).

3. Carbon fertilisation effects: the crop simulation models were run with and without carbon fertilisation effects on crop yields. Therefore, we consider in the analysis crop responses to elevated atmospheric $\mathrm{CO} 2$ concentrations and their implications on crop physiology, which differ among species (C3 and C4). Whilst most studies conclude that carbon fertilisation has a positive effect on crop yields under idealized conditions, the real effect on crop productivity in the field remains an issue for further research as little is known about the interaction of elevated $\mathrm{CO} 2$ concentrations with other factors such as crop diseases or nutrient availability.

Table 1: Scenario characterization to assess climate change impacts on agricultural markets.

\begin{tabular}{lccc}
\hline \multicolumn{1}{c}{ Code } & RCP & GCM & CO $_{2}$ effects \\
\hline HADGEM2_8.5_CO2 & RCP 8.5 & HadGEM2 & Simulated \\
IPSL_8.5_CO2 & RCP 8.5 & IPSL & Simulated \\
HADGEM2_8.5_noCO2 & RCP 8.5 & HadGEM2 & Non-simulated \\
IPSL_8.5_noCO2 & RCP 8.5 & IPSL & Non-simulated \\
HADGEM2_4.5_CO2 & RCP 4.5 & HadGEM2 & Simulated \\
IPSL_4.5_CO2 & RCP 4.5 & IPSL & Simulated \\
HADGEM2_4.5_noCO2 & RCP 4.5 & HadGEM2 & Non-simulated \\
IPSL_4.5_noCO2 & RCP 4.5 & IPSL & Non-simulated \\
\hline
\end{tabular}

*RCP (Representative Concentration Pathway); GCM (Global Circulation Model) 


\subsection{Understanding interconnections within the WEF nexus: Fuzzy cognitive mapping}

\subsubsection{Fuzzy Cognitive Maps}

Fuzzy Cognitive Maps (FCMs) represent the behaviour of complex systems based on people's perceptions. FCMs are based on cognitive maps that are graphical representations of causal relationships among variables in a system. These variables can be quantifiable (e.g., temperatures) or not (e.g., water policy). The direction of the causal relationship is represented with signed arrowheads. A positive sign represents a direct causal relationship (a rise in variable $A$ will increase variable $B$ ), while a negative sign shows an inverse relationship (a rise in variable A will reduce variable B). Axelrod (1976) was the first to use binary cognitive maps to elicit people's perceptions of a system. As causality is uncertain, Kosko (1986) extended the binary causal relationships ( 0 or 1 ) by introducing fuzziness in cognitive maps, allowing for in-between states [-1 to 1]. Each interrelation between two variables $v_{i}$ and $v_{j}$ is assigned a weight $w_{i j}$ that takes a value between -1 and $1: w_{i j}>0$ indicates a positive causal relationship, meaning that an increase (decrease) in the value of $v_{i}$ leads to an increase (decrease) in the value of $v_{j}$ (the higher the weight the stronger the causal relationship); $w_{i j}<$ 0 determines a negative causal relationship, where an increase (decrease) in the value of $v_{i}$ drives to a decrease (increase) on the value of $v_{j} ; w_{i j}=0$ depicts no causality between $v_{i}$ and $v_{j}$ (Papageorgiou and Kontogianni, 2012).

FCM builds on stakeholder understanding and experience of the system. The knowledge elicitation process to develop the FCMs can be performed from questionnaires, by literature review, from data or from interviews where participants individually or in groups develop a map (Özesmi and Özesmi, 2004). The number of stakeholders engaged in the process varies widely among FCM studies from, for example, seven considered by Solana-Gutierrez et al. (2013) to 188 stakeholders considered by Reckien (2014).

FCMs are represented in the matrix form $E=\left[w_{i j}\right]$, where variable $v_{i}$ is placed on the vertical axis and variable $v_{j}$ on the horizontal axis. The causal relationship between two variables $\left(w_{i j}\right)$ is indicated in the matrix (range from -1 to 1 as mentioned before). Aggregation of individual maps to create the group or social map enables the combination of multiple knowledge sources and helps in understanding complex systems (Özesmi and Özesmi, 2004; Gray et al., 2014). To that end, variables from individual maps are subjectively grouped into broader concepts. Based on these concepts, individual matrices are augmented and condensed through matrix aggregation to create the group matrix (Özesmi and Özesmi, 2004). 
The structure of FCMs can be analysed through matrix indices from graph theory (Harary et al., 1969):

- Density $(D)$ provides information on the connectivity of the maps. This index is estimated as the relationship between the number of connections and the maximum number of possible connections between the map's variables:

$$
D=\frac{C}{N(N-1)}
$$

where $D$ is the density of the map, $C$ is the total number of connections and $N$ is the number of variables.

- Outdegree $(o d)$ represents the total strength of connections outflowing from the variable. The index is calculated as the horizontal summation of a variable's absolute values:

$$
o d\left(v_{i}\right)=\sum_{k=1}^{N} w_{i k}
$$

where $\operatorname{od}\left(v_{i}\right)$ is the outdegree of variable $v_{i}$ and $w_{i k}$ represents the weight in rows.

- Indegree (id) computes the total strength of connections inflowing to the variable. The index is estimated as the vertical summation of a variable's absolute values:

$$
i d\left(v_{i}\right)=\sum_{k=1}^{N} w_{k i}
$$

where $i d\left(v_{i}\right)$ is the indegree of variable $v_{i}$ and $w_{k i}$ represents the weight in columns.

- Centrality $(c)$ of a variable shows the cumulative strength of connections of this variable to other variables. The index is calculated as the sum of the variable's indegree and outdegree: 


$$
c_{i}=t d\left(v_{i}\right)=\operatorname{od}\left(v_{i}\right)+i d\left(v_{i}\right)
$$

where $c_{i}$ is the centrality of the variable $v_{i}, t d\left(v_{i}\right)$ is the total degree of the variable $v_{i}, \operatorname{od}\left(v_{i}\right)$ is the outdegree of variable $v_{i}$ and $i d\left(v_{i}\right)$ is the indegree of variable $v_{i}$.

The variables within a map can be classified into different types according to their outdegree and indegree: Transmitter variables (positive outdegree and zero indegree) are considered drivers of the system, receiver variables (zero outdegree and positive indegree) are dependent variables and ordinary variables (both zero outdegree and indegree) are means. The relationship between the number of receiver and transmitter variables $(R / T)$ is an index of complexity of the system. A high number of receiver variables means that many results can emerge from the system. In contrast, many transmitter variables reflect numerous forcing functions, suggesting that causal relationships are poorly developed (Özesmi and Özesmi, 2004; Papageorgiou and Kontogianni, 2012).

The system's behaviour can be analysed through scenario simulation (Papageorgiou and Kontogianni, 2012) following a two-step process: First, the initial value for each of the vector's elements, also called activation level, is multiplied with the adjacency matrix to create a new vector. The activation level takes a value ranging between 0 and 1: 0 implies that the variable does not exist in the system in a specific iteration, while 1 means that the variable is present to its full extent. In-between values depict intermediate activation levels. After assigning the activation level (equals 1 for all the variables), the converted vector is iteratively multiplied by the adjacency matrix. The state value of each variable $v_{i}$ in a subsequent iteration is determined by its value in the previous iteration and the value of all the interconnected variables (Papageorgiou and Kontogianni, 2012).

$$
A_{i}^{(k+1)}=f\left(A_{i}^{k}+\sum_{\substack{j \neq i \\ j=1}}^{N} A_{j}^{k} * w_{j i}\right)
$$

where $A_{i}^{(k+1)}$ is the value of the variable $v_{i}$ at the simulation step $k+1, A_{i}^{k}$ is the value of variable $v_{i}$ at step $k, A_{j}^{k}$ is the value of variable $v_{j}$ at step $k, w_{j i}$ is the weight of the interrelation between variable $v_{j}$ and variable $v_{i}$ and $f$ is the activation function. 
To keep results within the interval $[0,1]$, a logistic function is used:

$$
f(x)=\frac{1}{1+e^{-x}}
$$

where $\mathrm{x}$ is the value of $A_{i}^{(k)}$ in the equilibrium point.

After a number of iterations, the system can achieve steady state equilibrium (the state value of each variable $v_{i}$ converges over a number of iterations), move towards a limit cycle (only some values are repeated) or show a chaotic pattern (different values in each iteration) (Kosko, 1986).

Second, simulation scenarios are run following the same procedure but, in this case, the activation levels of the variables defining the scenario remain the same during the iterations (Kosko, 1986). Results from simulation scenarios are presented as a relative change to the steady state. Alternative simulation scenarios allow for exploring the behaviour of the system and understanding its complex interrelations.

\subsubsection{Study region: Andalusia (Spain)}

Located in southern Spain, Andalusia is the most populous Spanish region with 8.4 million people and the second largest region with $87,600 \mathrm{~km}^{2}$ (Figure 8). The regional economy builds on the services sector, which accounts for $75.5 \%$ of Gross Domestic Product (GDP) and employs 2.3 million people (76.6\% of the total people employed). The industrial sector represents $12.7 \%$ of the GDP and employs 264,000 people, of which 60,200 people perform work in the food industry. The primary sector contributes to GDP in 5.5\% and provides employment for 263,100 people. Trade of agri-food products plays an important role in the regional economy, representing one-third of the total exports. The value of agri-food exports has increased sharply since 1990, amounting to 10,787 million euros in 2017. In terms of commodities, the region is a major provider of vegetables and fruits to the European market, and worldwide exporter of olive oil (Junta de Andalucía 2018a). 


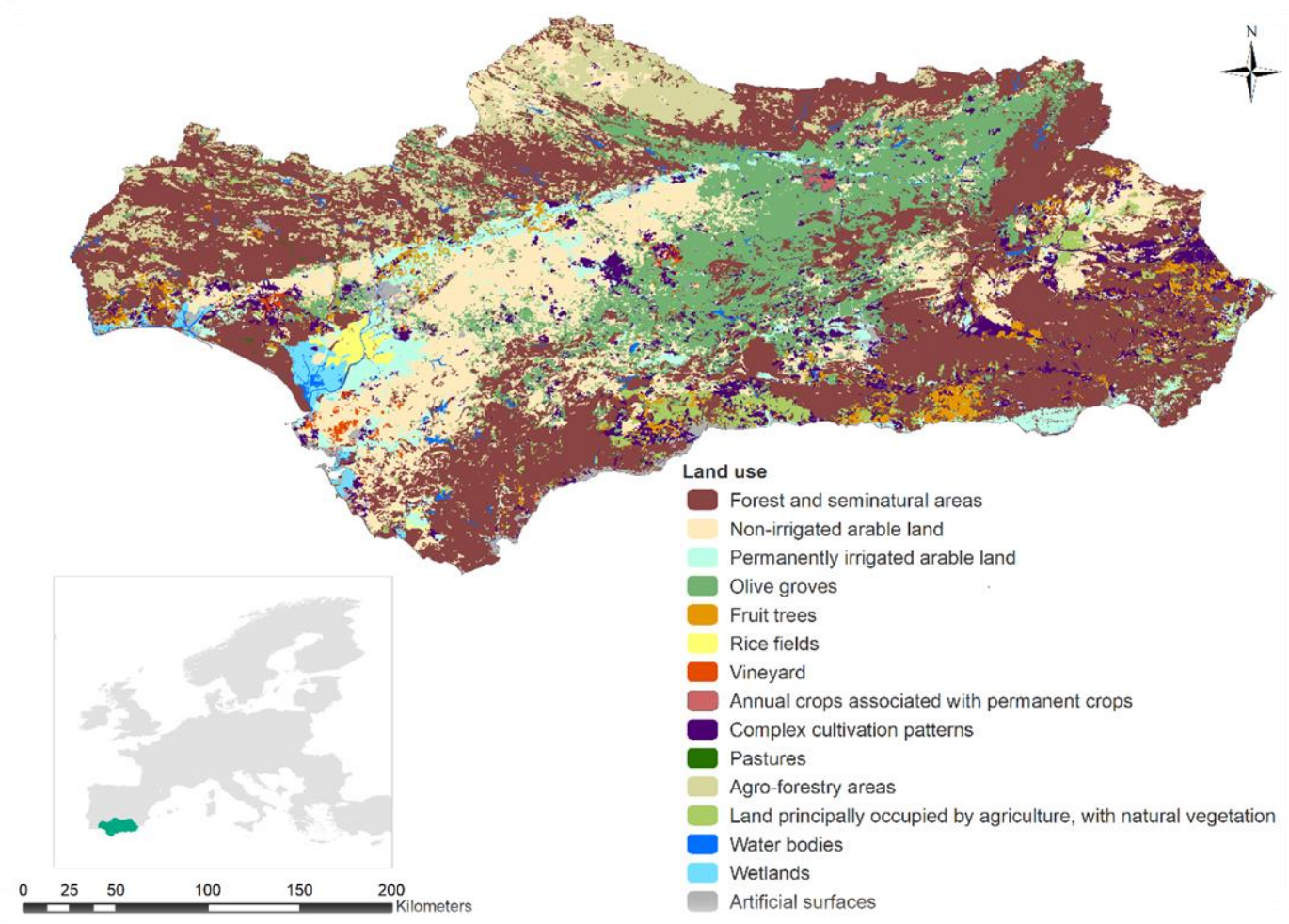

Figure 8: Location of Andalusia and main types of land use.

The Utilised Agricultural Area ${ }^{3}$ (UAA) in Andalusia covers 4.7 million ha of which one million ha are under irrigation, representing over a quarter of the total irrigated land in Spain. The soil and climate diversity in the region leads to an extraordinary variety of agricultural production. The agricultural potential largely depends on irrigated agriculture, which generates more than $64 \%$ of the total value of agricultural production in Andalusia and accounts for $63 \%$ of agricultural employment (Massot, 2016). Olive trees are by far the most predominant irrigated crop, encompassing $46 \%$ of the irrigated land in Andalusia, followed by cereals (14\%), vegetables $(12 \%)$, industrial crops $(9 \%)$, citrus fruits $(8 \%)$, other fruit trees $(5 \%)$ and fodder crops (2\%). In terms of water use $\mathrm{s}^{4}$, arable crops accounts for $30 \%$ of the agricultural water withdrawal in the region, mainly due to the production of crops such as rice and cotton, followed by fruits trees (22\%), olive trees (19\%) and vegetables $(10 \%)$.

According to the Economic Accounts of Agriculture ${ }^{5}$, vegetables and fruits are the largest contributors to the agricultural production value, representing more than $60 \%$ of the total

\footnotetext{
${ }^{3}$ Andalusian Yearbook of Agricultural and Fishery Statistics (2016)

${ }^{4}$ National Institute of Statistics (INE) - Survey on the water use in the agricultural sector (2016)

${ }^{5}$ Regional Economic Accounts for Agriculture
} 
crop production value. Meanwhile, olive oil accounts for $22 \%$ of the total value, whereas cereals and oilseeds contributions are in the order of $3 \%$ and $4 \%$ respectively.

In total, irrigated agriculture accounts for about $80 \%$ of total water withdrawals in the region (Junta de Andalucía, 2018c). The high water demand combined with wide fluctuations in available water due to rainfall variability has created a delicate water balance in the different river basins of the region (Berbel et al., 2013; Peña-Gallardo et al., 2016). Efforts of the public administrations to reduce water use in agriculture through different irrigation plans targeted the improvement and development of water infrastructures as well as the replacement of the traditional surface irrigation systems with drip and sprinkle irrigation methods. As a result, drip irrigation systems cover $64 \%$ of irrigated land, whereas sprinkler systems and surface irrigation span over $13 \%$ and $23 \%$ of irrigated land, respectively. The modernisation process has increased average water use efficiency to 0.76 in the region and reduced average water use to $3572 \mathrm{~m}^{3} /$ ha, though this figure varies significantly across crops (e.g., fruits and vegetables use over $5000 \mathrm{~m}^{3} / \mathrm{ha}$ ) (Junta de Andalucia, 2011).

The implementation of more efficient irrigation systems has played an important role in the attainment of short-term water savings, but they might trigger increases in water demand in the medium term. The rebound effect arises from the growing interest in high value crops due to higher water supply guarantees and better quality of irrigation systems (Berbel et al., 2019; Fernandez Garcia et al., 2014), and also to decoupled payments of the CAP that encourage agricultural production adaptation to markets (Corominas, 2011; Garcia-Vila et al., 2008; Lopez-Gunn et al., 2012).

An unexpected effect of irrigation plans has been the dramatic rise in the energy dependence of the agricultural sector following the replacement of traditional irrigation systems with pressurised systems. The higher energy requirements, along with the energy market liberalisation in 2008, have significantly increased irrigation costs (Corominas 2010; RodríguezDiaz et al., 2011b).

Policy incoherence across sectors in this region has resulted in increasing conflicts among WEF nexus sectors that have negatively affected resource sustainability (Lopez-Gunn et al., 2012; Salmoral and Garrido, 2015; Sampedro and Del Moral, 2014). A recent report on the on the implementation of the WFD (EC, 2019b) shows that water abstraction remains high, with the 
water exploitation index $(\mathrm{WEI}+)^{6}$ over the threshold of $40 \%$ due mainly to irrigation water withdrawn in some river basins, such as the Guadalquivir (EC, 2019b). In addition, the ex-post evaluation of the Rural Development Programme (RDP) in Andalusia over the period 20072013 concludes that, although the RDP has had a positive impact in resource use efficiency and environmental preservation, there is a need to strengthen coordination between the different decision-makers to consider cross-sectoral interdependencies.

Most previous studies with reference to the nexus in Andalusia partially examined the WEF nexus considering two-sector interrelationships; in particular, water and energy or water and agriculture (De Stefano and Llamas, 2012; Hardy et al., 2012). Nevertheless, full comprehension of the interdependencies in the WEF nexus in the region is crucial to avoid unexpected effects and to design effective nexus-compliant strategies. This can only be achieved with the involvement of decision-makers in the process, to ensure integration of multiple perspectives, political legitimacy, as well as consensus building (De Marchi and Ravetz, 2001).

\subsubsection{Stakeholders' participation}

Stakeholders from the water, food and energy sectors in Andalusia were identified through an online investigation and snowball sampling (Noy, 2008). The selection criteria were to gather experts from the different nexus sectors both at the public and private levels. Therefore, 14 representatives from the regional administration, professional organisations, nongovernmental organisations (NGOs) and research centres and universities were selected and contacted. The number of stakeholders engaged brought together a broad range of perspectives needed to interpret the interlinkages in the nexus.

As a preliminary step, we conducted phone or face-to-face semi-structured interviews with the selected stakeholders. Seven guiding questions served to get a preliminary understanding of stakeholders' views on major nexus challenges in Andalusia. The guiding questions were sent via email to the stakeholders before the interview. The semi-structured interviews lasted for approximately $45 \mathrm{~min}$ to one hour.

A one-day workshop held in the Regional Government of Agriculture, Fishing and Rural Development in Seville in October 2017 brought together the stakeholders. The portion of the

\footnotetext{
${ }^{6}$ According to EUROSTAT, the water exploitation index $(\mathrm{WEI}+)$ relates country-specific water abstraction with its long-term annual average available renewable water resources.
} 
workshop dedicated to stakeholders' participation consisted of two sessions: (1) individual mapping and (2) discussion of policy objectives. After explaining cognitive maps using an example, each participant was asked to build a cognitive map to respond to the question: What are the main interlinkages in the water-energy-food nexus in Andalusia? Participants were free to select the map variables to represent their perspectives without restraint. The magnitudes of the causal relationships between the variables were weighted with a value between -1 and +1 . As a result of the first session of the workshop, 11 individual maps built by six representatives from the regional administration as well as representatives from two professional organisations, one NGO and two research centres were obtained. Figure 9 shows one of those individual maps, illustrating the type of information provided by workshop's participants. Three stakeholders either left early or arrived late so that they missed the section that was dedicated to individual map drawing.

After the individual mapping, a round-table discussion during the second half of the workshop offered insights into main nexus challenges in Andalusia. According to these challenges, the group discussion enabled the description of two policy objectives and the corresponding measures to achieve each of them. This valuable information constituted the base for the scenario simulation in this thesis.

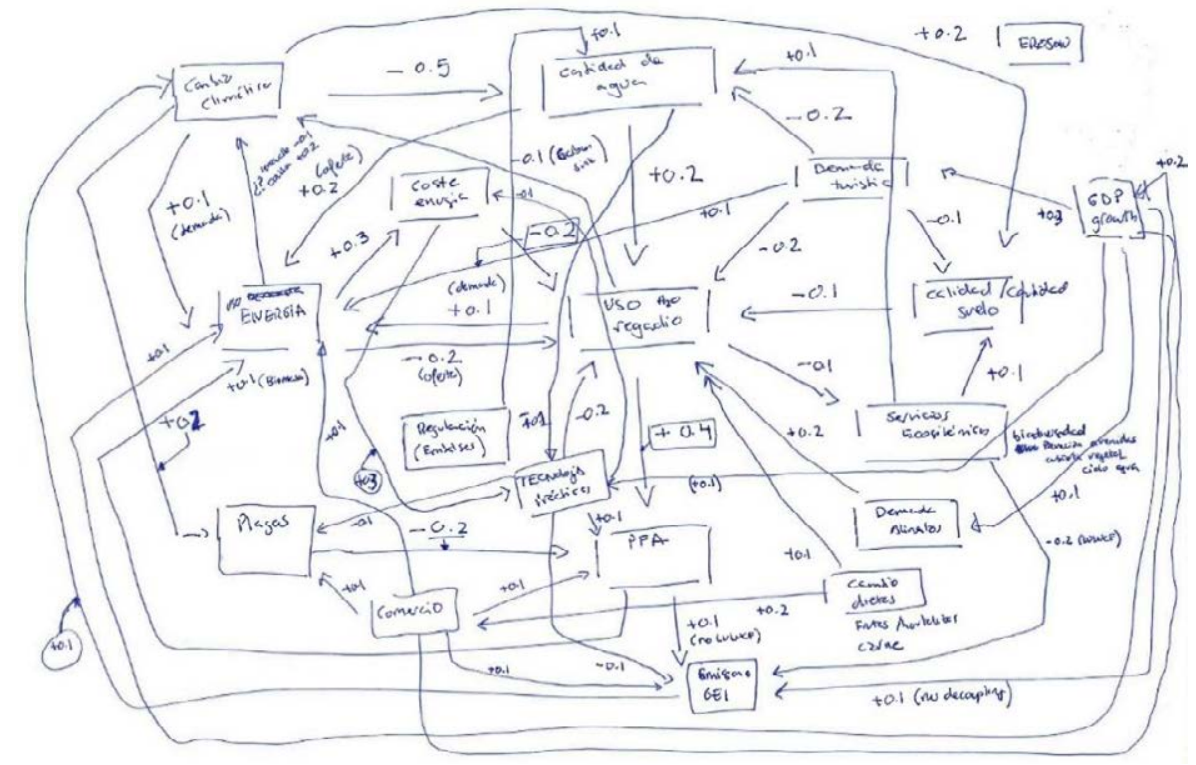

Figure 9: Example of an individual map drawn by stakeholders. Boxes represent the variables identified by the stakeholder. Arrows depict the cause-effect relationship between variables. Number values represent the strength of the causal relationship, where the sign depicts a positive (+) or negative (-) causal relationship and the value between 0 and 1 represents the magnitude. 


\subsubsection{Data processing and analysis}

The eleven individual maps built by stakeholders represented the raw data to develop the FCM. The first step in the data processing was to list all variables included in the individual maps and to relate them to the nexus sectors. As stakeholders used different words to define the same concept, we harmonised variable terminology (e.g., crop intensification, production intensification and agricultural intensification were harmonised as "intensification of agricultural production"). Less-repeated variables were aggregated into broader categories according to similarities (e.g., plagues and exotic species were merged in the variable "plagues") and the names of the variables were standardised across maps. This subjective aggregation condensed 206 variables into 35 standardised variables facilitating the understanding and the analysis of the maps.

Using the standardised variables, we converted each individual map into a matrix. When a causal relationship between two variables was identified by the stakeholder, the same strength of influence provided in the individual map (ranging between -1 and 1 ) was coded in the matrix (weight $w_{i j}$ ). When no causal relationship was given in the individual map, zero was used. Once the individual maps were converted into matrices, all those individual matrices were augmented and merged into a single aggregated matrix to deliver the group map. The connection values between two specific variables were summed and averaged over the total number of individual maps. In the aggregated map, contradictory relationships between two given variables in different individual maps (opposite sign) decrease the causal relationship, while consensus on interlinkages (same sign) strengthens the causal relationship.

\subsubsection{Scenario analysis}

The group matrix is used to run alternative simulation scenarios with the FCMapper software ${ }^{7}$. The definition of scenarios built on the policy objectives identified by stakeholders during the workshop as mentioned before:

- Scenario 1: Climate change mitigation

Stakeholders highlighted climate change as one of the major challenges in the WEF nexus. To address this challenge, the reduction in diffuse emissions is established as a major target. Some of the measures proposed to achieve this objective were to promote efficient agricultural machinery and good agricultural practices (carbon capture, reduction of tillage,

\footnotetext{
${ }^{7}$ FCMapper software - http://www.fcmappers.net/joomla/
} 
precision agriculture, use of sensors, smart agriculture), reduce methane emissions and enhance renewable energies.

Based on this information, we simulated a first scenario considering an improvement in agricultural practices (variable "farming practices" set to 1 ) and an increase in the use of renewable energies (variable "use of renewable energies" set to 1 ).

- Scenario 2: Sustainable water resources management

Water availability is another key factor in the WEF nexus, especially for irrigated agriculture, which is by far the largest water user in Andalusia. Stakeholders considered that a reduction in water demand for irrigation is crucial to promote sustainable resource management. To that end, they proposed improvements in water infrastructures and management as well as measures to reduce diffuse pollution.

According to this information, the second scenario simulated the improvement of water infrastructures (variable "water infrastructures" set to 1) and water quality (variable "water quality" set to 1 ).

\subsection{Disentangling key water-related drivers of future agricultural development: Sensitivity analysis}

\subsubsection{Sensitivity analysis}

Sensitivity analysis techniques assign uncertainty in model output to model input, enabling the identification of the key drivers of model results (Saltelli, 2002). There are different approaches to conducting a sensitivity analysis that are frequently classified into local and global methods. The local methods explore variations in model results with regards to variations of an input factor around a given point, whereas the global approaches contemplate the whole range of variability of the input factors. Additionally, sensitivity analysis tools can be divided into OAT and ATT methods, referring to assessing output variations when changing one input factor at a time or all the input factors at once (Saltelli et al., 2008; Norton, 2015; Borgonovo and Plischke, 2016; Pianosi et al., 2016). Whereas local methods are normally conducted in a deterministic framework by applying OAT techniques, global methods considers the probability distribution of model inputs and are based on ATT tools.

Global sensitivity analysis generally build on Monte Carlo simulation to generate random draws that follow the distribution of model inputs (looss and Lemitre, 2015; Saltelli et al., 
2008), yet the number of simulations required increases exponentially we have multi-variate distributions. Beyond limitations in terms of computational cost for large-scale economic models, applying probabilistic approaches may prompt unfeasible parameter distributions, because economic models include sets of parameters that are correlated.

Bearing in mind the complexity of the global agro-economic model CAPRI, we apply a local method as an alternative to global methods, therefore assuming a set of plausible values instead of probability distributions for the parameters. To overcome the limitations of OAT methods, which only capture individual effects, we have chosen a method that investigates both individual and interaction effects at a feasible computational cost. Therefore, we have applied SA with finite changes, a method that decomposes the finite change in model output $(\Delta y)$ triggered by a shift in model input $x$ from the reference case $\left(x^{0}\right)$ to the sensitivity case $\left(x^{1}\right)$ [Eq. 7 and 8] (Borgonovo, 2010).

$$
\Delta y=g\left(x^{1}\right)-g\left(x^{0}\right)=\sum_{i=1}^{n} \Delta_{i} g+\sum_{i<j}^{n} \Delta_{i, j} g+\cdots \Delta_{1,2, \ldots n} g
$$

Where

$$
\begin{gathered}
\Delta_{i} g=g\left(x_{1}^{0}, x_{2}^{0}, \ldots x_{i-1}^{0}, x_{i}^{1}, x_{i+1}^{0}, \ldots, x_{n}^{0}\right)-g\left(x^{0}\right) \\
\Delta_{i, j} g=g\left(x_{1}^{0}, x_{2}^{0}, \ldots x_{i-1}^{0}, x_{i}^{1}, x_{i+1}^{0}, \ldots, x_{j-1}^{0}, x_{j}^{1}, x_{j+1}^{0}, \ldots x_{n}^{0}\right)-\Delta_{i} g-\Delta_{j} g-g\left(x^{0}\right)
\end{gathered}
$$

The first order terms $\Delta_{i} g$ quantify the individual effect of changing input $x_{i}$ alone from the reference to the sensitive case. The second order terms $\Delta_{i, j} f$ express the amount of change in model outcome due to the interaction effects between input factors $x_{i}$ and $x_{j}$ and is computed as simultaneously changing both inputs to $x_{i}^{1}$ and $x_{j}^{1}$ and subtracting the individual effects. Higher-order terms $\left(\Delta_{1,2, \ldots n} f\right)$ follow the same rationale.

Sensitivity indices capture individual and interaction effects according to the following definitions: 


$$
\begin{aligned}
& \varphi_{l}^{1}=\Delta_{l} g \\
& \varphi_{l}^{T}=\Delta_{l} g+\sum_{l \neq j}^{n} \Delta_{l, j} g+\cdots \Delta_{1,2, \ldots n} g \\
& \varphi_{l}^{I}=\varphi_{l}^{T}-\varphi_{l}^{1}
\end{aligned}
$$

$\varphi_{l}^{1}$ depicts the individual effect of input I on model output explained by the change of input $x_{i l}$ alone [Eq. 9]. $\varphi_{l}^{T}$ expresses the total effect of input $/$ derived from the shift in input $x_{i l}$, along with the interaction effects [Eq. 10]. $\varphi_{l}^{I}$ represents interaction effects and is computed by subtracting individual effects from the total effects [Eq. 11].

According to Eq. 12 with $n$ being the number of parameters analysed, the total effects can be calculated in $n$ model runs, instead of $2^{n}$ runs that is expected in a two level factorial design. Moreover, the estimation of $\varphi_{l}^{1}$ requires $n$ model runs. Therefore, the total computational cost equals to $2 n+1$ model runs, which makes this method highly suitable for large models.

$$
\varphi_{l}^{T}=\Delta y-\Delta y_{(-l)}=g\left(x^{1}\right)-g\left(x_{(-l)}^{1}\right)
$$

where $\Delta y$ is the change in $y$ when all inputs vary, $\Delta y_{(-l)}$ is the change in y when all inputs vary except $x_{l}$ and $x_{(-l)}^{1}$ is the outcome when changing all inputs at the sensitive case while keeping $x_{l}$ at the reference case.

Sensitivity indices can be represented in generalised Tornado diagrams where, for each input, individual, interaction and total effects on the model outcome are displayed as horizontal bars ranked from the most to the least significant input according to the total effects (Eschenbach, 1992).

This approach has been recently applied to assess the sensitivity of long-term $\mathrm{CO}_{2}$ emissions to the different drivers under the SSPs (Marangoni et al. 2017). Further application areas include, for instance, operational decision-making (Borgonovo and Smith, 2011; Borgonovo and Peccatti, 2011). 


\subsubsection{The CAPRI-Water model}

CAPRI captures the interplay between agricultural production and the environment in detail and, thereby, it is able to compute a number of agro-environmental indicators (e.g., nutrient balances, GHG emissions). As a major strength, the model is highly suitable to assess climate change impacts on agricultural and food systems, based on climate-induced changes in crop yields, as provided by crop models (Shrestha et al., 2013; Blanco et al., 2017). The recent update of the model further enhances its capacity to explore climate change impacts on agriculture by considering the water dimension. The interface between agriculture and water is likely to become increasingly important under climate change conditions (IPCC, 2013) and, thus there is a need to investigate the water-food nexus.

The CAPRI-Water model incorporates irrigation water use in the standard supply module (Blanco et al., 2018). Within the irrigation sub-module, land is differentiated into non-irrigable (water comes from rainfall) and irrigable (equipped for irrigation and likely to be irrigated) based on the data from the Farm Structure Survey (FSS) issued by EUROSTAT. Irrigable land constitutes the maximum threshold to irrigated land at the NUTS 2 level. An activity is considered irrigable when it has been reported under irrigation in at least one Member State.

Input-output coefficients are defined for both rain-fed and irrigation options for all irrigable activities, adding irrigation water use in the case of irrigation variants. Crop net actual irrigation water use is computed for each crop and NUTS 2 region based on theoretical cropspecific water requirements and effective rainfall obtained from CROPWAT model, rainfed/irrigation shares and crop yields. The distinction between rain-fed and irrigation yields builds on the ratio potential yield/water limited yield obtained from the WOFOST model (Blanco et al., 2018).

Gross irrigation water use is calculated considering water application and transport efficiencies from the literature. Water application efficiency relies on the irrigation method and management practices, ranging from 0.6 to 0.9 (Brower et al., 1989). Regional water application efficiency is estimated based on the reference values for each irrigation method (surface, sprinkler and drip irrigation) and the share of area covered by irrigation methods from the FSS. Water transport efficiency depends on the water infrastructures conditions (e.g, permeability of canals) and varies between 0.60 and 0.95 according to Brower et al. (1989). 


\subsubsection{Drivers selection and definition}

Drivers for this analysis were identified through a stakeholder consultation process in the framework of the Andalusian case study within the H2020 SIM4NEXUS project. Exploring uncertainty-related concerns from stakeholders is an essential element to derive valuable insights for decision-making (Gabbert et al., 2010; Höllermann and Evers, 2017). In this approach, the drivers of future irrigated agriculture development in Andalusia were selected in the course of two workshops gathering stakeholders from different sectors both at public and private level (please see Annexes 4 and 5 for further details on the agenda). The first workshop, held in October 2017, aimed to identify the main challenges in the WEF nexus, and climate change and water were widely recognised as major challenges to promote sustainable agriculture in the region (please see section 3.3.3. for further details). In the second workshop, held in November 2018, the focus was on policy scenarios to tackle the identified challenges, and water availability for agriculture, irrigation efficiency and irrigation costs were highlighted as the main drivers of uncertainty.

\section{Water availability for irrigation}

Climate change is likely to exacerbate water stress in Andalusia over the next years. Roudier et al. (2016) have foreseen more severe and longer droughts in the region mainly due to less precipitation and higher evapotranspiration. Donelly et al. (2017) concluded that observed reductions in runoff in southern Spain in response to different levels of global warming might constrain water availability and agricultural production. Furthermore, Garrote et al. (2015) highlighted a reduction in the maximum potential water withdrawal for irrigation in virtually all the Mediterranean basins, with the most significant decrease being observed in the Guadalquivir, the largest river basin in Andalusia.

According to the Centre for Public Works Studies and Experimentation (CEDEX) from the Spanish Ministry of Public Works and Transport, under RCP 8.5, the estimated average reduction in runoff for the different river basins of the region ranges from 10 to $12 \%$ for the period 2010-2040 and from 18 to $20 \%$ for the period 2040-2070 in comparison to the reference period 1961-2000. When considering the RCP 4.5, the estimated reduction varies between 2-7 \% for the period 2010-2040 and 8-12\% for the period 2040-2070 (CEDEX 2017).

Specific projections on water availability for agriculture under climate change are highly uncertain and are not easily accessible. For this exploratory analysis, we assume the same range of variation for water availability in agriculture as considered for runoff in CEDEX (2017). 


\section{Irrigation efficiency}

Irrigation efficiency is defined as the ratio of crop irrigation water requirements to irrigation water withdrawal (Perry, 2007; Seckler et al., 2003). In this regard, Perry (2007) stated the need to differentiate consumed water, which can be beneficial for irrigated crops (i.e., water transpiration) or not (i.e., evaporation from water surface), and non-consumed water in irrigation, which can either be recovered for other uses (i.e., return flows) or not (e.g., flow to saline groundwater). Irrigation efficiency considers water conveyance efficiency, associated to water transport and distribution, and water application efficiency, related to irrigation systems (i.e., surface, drip and sprinkler irrigation). The different irrigation plans over the period 2002-2015 substantially enhanced irrigation efficiency in Andalusia to 0.76 on an average (Junta de Andalucia, 2011). Improvements on irrigation efficiency might continue in the future with the implementation of water policies (EC, 2012a) and the adoption of new technologies (Morillo et al., 2015; Gonzalez Perea et al., 2017; Intrigliolo and Alarcón, 2017). Nevertheless, the pace of growth remains uncertain, as it depends on diverse factors such as investments on more efficient techniques and agricultural management practices.

A number of studies have recently explored future developments in irrigation efficiency under different assumptions. Fisher et al. (2007) assumed an efficiency gain of $10 \%$ from 2000 to 2030 and a further $10 \%$ increment from 2030 to 2080 across regions. Schmitz et al. (2013) stated that there will be an increase in irrigation efficiency based on GDP per capita growth over time. The Water Future and Solutions Initiative (WFaS) have addressed the need for comparable and consistent global water scenarios by incorporating the water dimension within the SSP framework (Burek et al., 2016; Wada et al., 2016). Thus far, qualitative scenario assumptions are available for the agricultural sector on the basis of storylines features for each driver under each SSP (Tramberend et al., 2015). First attempts to quantitatively explore water scenarios under SSPs include, for instance, that of Hanasaki et al. (2013), who simulated different scenarios compatible with the SSP framework with high, medium and low irrigation efficiency changes, assuming percent changes per year of $0.3,0.15$ and 0.0 , respectively. Bijl et al. (2018) and Doelman et al. (2018) simulated irrigation efficiency through the progressive reduction of the gap between water withdrawal and consumption of $0.10 \%$ and $0.04 \%$ for SSP1 and SSP2, respectively, while irrigation efficiency would remain at present levels under SSP3.

Due to the absence of common quantitative water scenarios for the agricultural sector at the present, we have considered two alternative options where the best-case scenario assumes 
an annual growth rate of irrigation efficiency of $0.10 \%$ and the worst-case scenario considers no change in irrigation efficiency over the coming decades.

\section{Irrigation costs}

Irrigation costs comprise system operation and maintenance, energy and water costs, the weight of each varying based on the origin of water (i.e., groundwater, surface water, etc.) and across river basins. On average, operation and maintenance costs represent $42 \%$ of total irrigation costs, whereas energy costs account for $37 \%$ and water costs for $21 \%$ in the Andalusian irrigated agriculture (Corominas, 2011).

System operation and maintenance costs cover benefits related with developing, managing and maintaining public water infrastructures. Energy costs in irrigated agriculture, associated with the implementation of pressurised systems, have notably augmented during the last years due to higher energy requirements of modernised irrigation systems. According to Corominas (2010), energy demand in irrigated agriculture in Spain has doubled from 1980 to 2007, shifting from $775 \mathrm{kWh} / \mathrm{h}$ a to $1560 \mathrm{kWh} / \mathrm{ha}$. Energy costs for irrigation have undergone a significant increase from 2009 following the replacement of the state-regulated tariff system with market-oriented pricing. In contrast, water costs that include tariffs and fees for the water services have remained broadly stable during the last decades (Calatrava et al., 2015).

Average irrigation costs in Andalusia amounts to 0.08 euro per $\mathrm{m}^{3}$ (Corominas, 2011). Future trends are difficult to predict as they are subject to energy market developments and energy and water policies, thereby remaining extremely uncertain. To investigate the potential effect of this driver, we have assumed an increase of 0.01 euro per $\mathrm{m}^{3}$ in 2050 in the baseline and two alternative options reflecting either no changes in irrigation costs or an increment in 0.02 euro per $\mathrm{m}^{3}$.

\subsubsection{Scenario framework}

The scenario framework designed to perform the sensitivity analysis draws on a reference scenario and two alternative scenarios where key drivers inform alternative model inputs. Scenarios are run for the year 2050 to capture climate change effects on agriculture.

The reference scenario is based on the CAPRI baseline and additionally considers climate change impacts on crop productivity under the RCP 6. Climate-induced changes in crop yields at the NUTS 2 level are provided by crop models, based on climate data from the global 
circulation model HadGEM2-ES. To account for uncertainties on future water availability, the reference scenario assumes an average decrease of $10 \%$ in water availability for agriculture in Andalusia according to CEDEX (2017). As mentioned, we have assumed an increase in irrigation costs in 2050 of 0.01 euro per $\mathrm{m}^{3}$ to capture potential future irrigation costs developments.

The alternative scenarios attempt to represent two sensitivity cases, the worst-case and the best-case scenarios, where the input parameter for the different drivers shifts from the reference value to better and worse values, respectively. The worst-case scenario assumes a $20 \%$ reduction in water availability, no change in irrigation efficiency rate and a rise in irrigation costs of 0.02 euro per $\mathrm{m}^{3}$ in 2050 . The best-case scenario considers a $2 \%$ reduction in water availability, irrigation efficiency gains of $0.1 \%$ per year and no changes in irrigation costs in 2050 (Table 2).

Table 2: Scenario framework to conduct the sensitivity analysis of CAPRI-Water results.

\begin{tabular}{|c|c|c|c|}
\hline & Reference scenario $\left(X^{0}\right)$ & Worst-case scenario $\left(X^{1}\right)$ & Best-case scenario $\left(X^{2}\right)$ \\
\hline $\begin{array}{l}\text { Water availability } \\
\text { for agriculture }\end{array}$ & $\begin{array}{l}\text { Average reduction of } \\
10 \% \text { in } 2050 \text { on CEDEX } \\
(2017)\end{array}$ & $\begin{array}{l}\text { Reduction in } 20 \% \text { in } \\
2050\end{array}$ & $\begin{array}{l}\text { Reduction in } 2 \% \text { in } \\
2050\end{array}$ \\
\hline $\begin{array}{l}\text { Irrigation } \\
\text { efficiency }\end{array}$ & $\begin{array}{l}\text { Increase in } 0.05 \% \mathrm{y}^{-1} \text { up } \\
\text { to } 2050 \text { according to } \\
\text { OECD (2013) }\end{array}$ & $\begin{array}{l}\text { No change in irrigation } \\
\text { efficiency }\end{array}$ & $\begin{array}{l}\text { Increase in } 0.10 \% \mathrm{y}^{-1} \\
\text { up to } 2050\end{array}$ \\
\hline Irrigation costs & $\begin{array}{l}\text { Increase in } 0.01 \text { euro per } \\
\mathrm{m}^{3} \text { in } 2050 \text {. }\end{array}$ & $\begin{array}{l}\text { Increase in } 0.02 \text { euro per } \\
\mathrm{m}^{3} \text { in } 2050 .\end{array}$ & $\begin{array}{l}\text { No changes in } \\
\text { irrigation costs in } 2050\end{array}$ \\
\hline
\end{tabular}

To conduct the sensitivity analysis, we have first computed the individual effects by changing each driver one at time from the reference value to the alternative values defined in scenarios $X 1$ and $X 2$. Then, we have shifted all drivers to either $X 1$ or $X 2$ except the one of interest to estimate its total effect. The interaction effect is calculated as the difference between total and individual effect. As the objective of this research is to explore the sensitivity of the model outcome to the selected drivers in the particular case of Andalusia, shifts in the drivers are only introduced for this single region and scenarios are run considering no changes in food prices. This procedure leads to two important assumptions that need to be considered when interpreting results: we assume no changes in all other regions and changes in Andalusia do not affect other regions. 


\section{Results}

\subsection{Impact of climate change in agricultural markets}

In order to assess the influence of climate change on agriculture in terms of food prices and market balances, the baseline (which assumes the current climate for 2030) is compared with the different simulation scenarios described in section 3.2.2 for the year 2030. The analysis focuses on climate change impacts on production globally and for the main traders of wheat, maize, soybean and rapeseed. We concentrate on these four products because they are major commodities in international trade and are substantially important in terms of trade in the EU. To evaluate the role of trade adjustments, we focus on the wheat market in the EU.

\subsubsection{Climate-induced effects on global agricultural production and prices}

Results from biophysical models show variations in crop yields because of climate change. Overall, global average yields increase when $\mathrm{CO}_{2}$ effects are considered and decrease when carbon fertilisation is not simulated. An exception to this pattern is observed in the HADGEM2 scenario with RCP 4.5 and without $\mathrm{CO}_{2}$ effects, where global yields for maize, rapeseed and soybean rise slightly (Figure 10). These global results may reflect the regional concentration of production of these crops and, therefore, their sensitivity to climate projections.

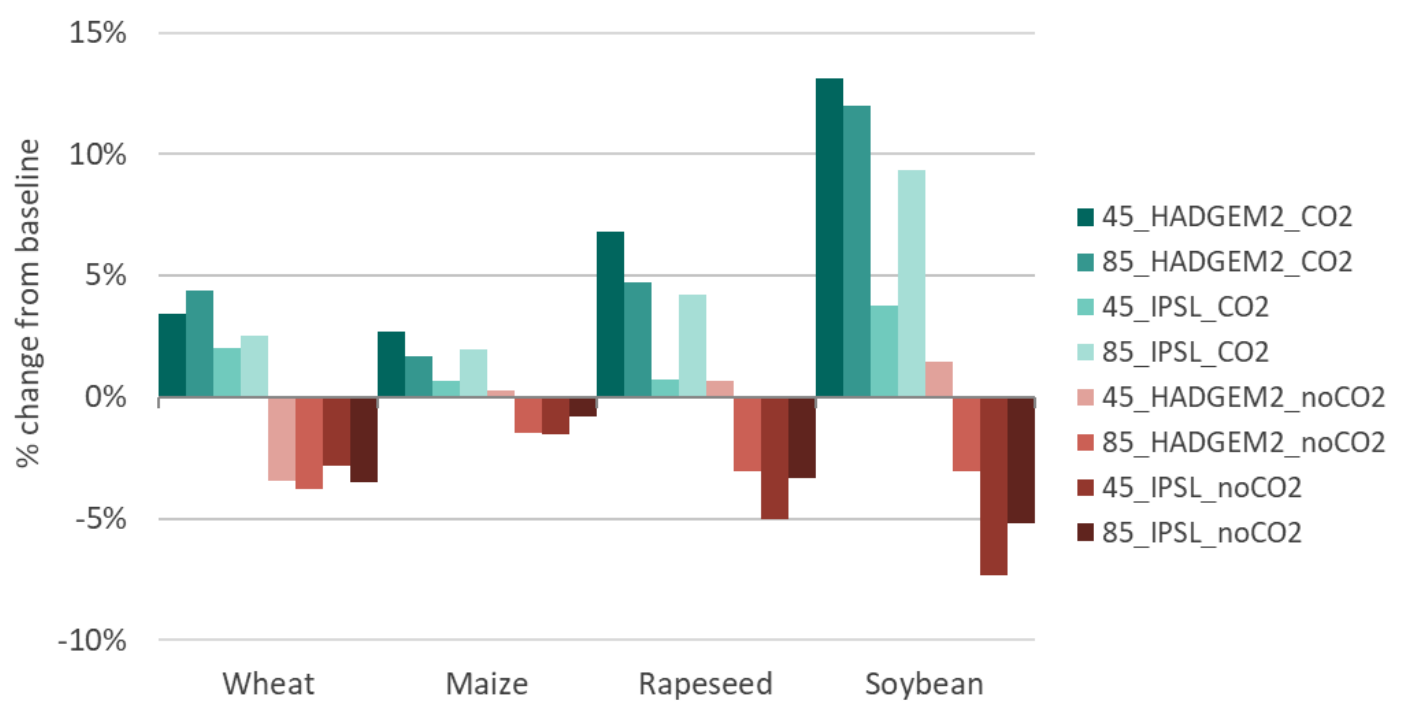

Figure 10: LPJmL-simulated global yields changes in 2030 for wheat, maize, rapeseed and soybean under different simulation scenarios. 
Results provided by the CAPRI model indicate that significant crop yield changes (i.e., from $7 \%$ to $+13 \%$ ) lead to moderate impacts in production (i.e., from $-1.5 \%$ to $+2.5 \%$ ), accompanied by large impacts on prices that range between $-20 \%$ to $+10 \%$. This provides evidence that global price changes soften the final impact of climate-induced yield changes in crop production (Figures 11a and 11b).

Focusing on production (Figure 11a), carbon fertilisation determines the direction of the impacts for maize and rapeseed: production increases with full fertilisation and decreases without carbon fertilisation. Wheat also follows the same pattern with the exception of scenario HADGEM2 RCP 4.5 without $\mathrm{CO}_{2}$ effects that presents a modest increase in production. Soybean production increase in all scenarios except for IPSL without carbon fertilisation. Despite these differences, production for all crops increase when carbon fertilisation effects are considered.

With regard to the differences between RCPs (4.5 and 8.5), there is not a straightforward pattern relating the magnitude of the effects. Though the extreme pathway did not seem to prompt the highest production levels in the case of full carbon fertilisation for the HADGEM2 projection, this does not apply to the IPSL model. The variability of the reported results corroborates therefore the need to use multiple climate models, as well as different RCPs, to comprehensively assess uncertainty.

With respect to prices, Figure $11 \mathrm{~b}$ shows that uncertainty was significantly higher for oilseeds (rapeseed and soybean) than for cereals (wheat and maize). Overall, the price of crops falls (rises) when production increases (decreases), though this is not always the case for soybean. This can be explained by the low elasticity of supply and demand for most agricultural commodities. 


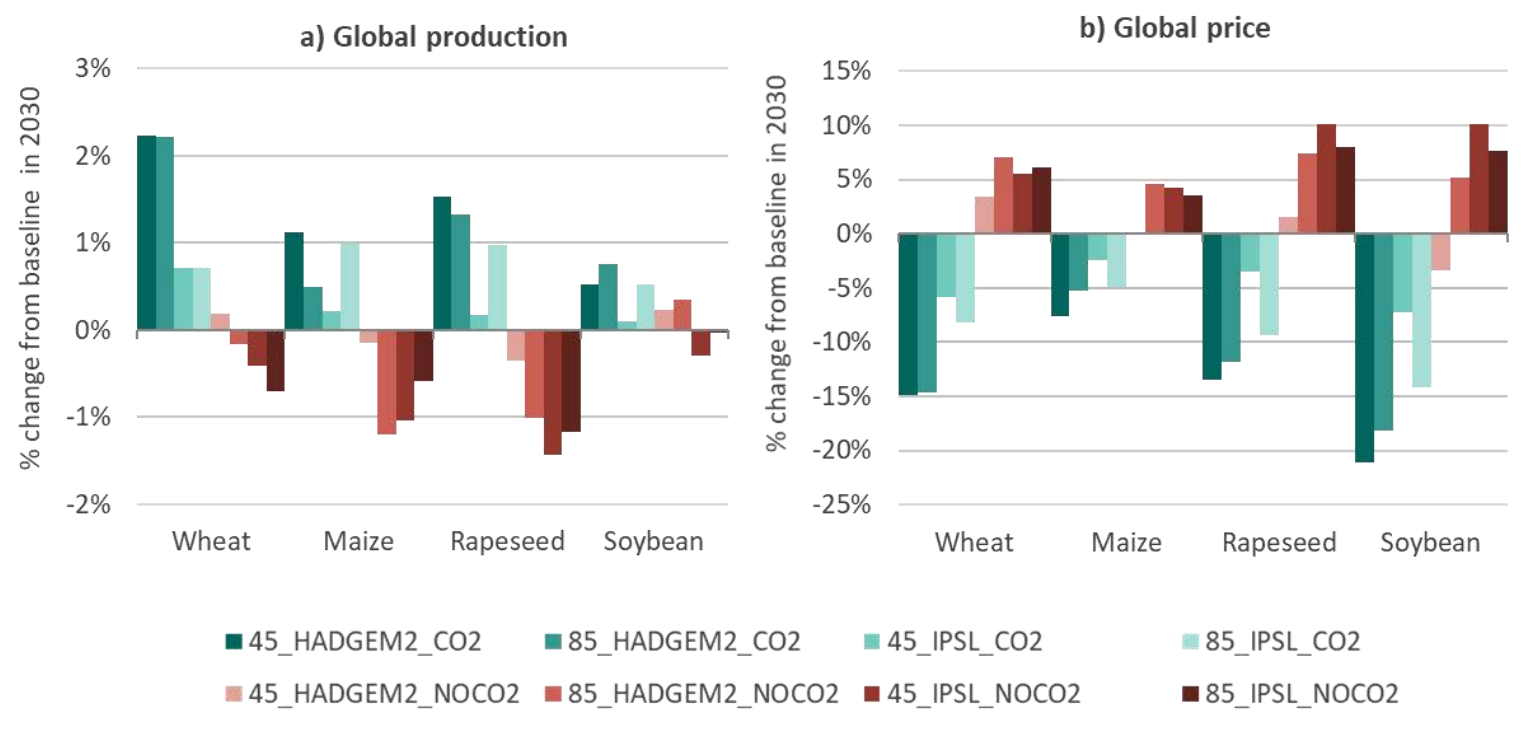

Figure 11: Changes in a) global production and b) global prices in 2030 for wheat, maize, rapeseed and soybean under different simulation scenarios (\% change relative to baseline values by 2030). Source: CAPRI model.

\subsubsection{Climate-induced effects on agricultural production for main traders}

Global average yield changes presented in Figure 10 conceal regional differences as shown in Annex 1. Carbon fertilisation leads to global yield increases for all crops, with disaggregated results showing varied effects. In order to address the different effects of climate change throughout the world, we studied the variations in production of the main exporters and importers for the selected crops (wheat, maize, rapeseed and soybean).

The major net exporters of wheat are the European Union (EU-28), the USA, Canada and Australia and New Zealand, with the major importers being the Middle East and North Africa (MENA), South-East Asia (SEA), Sub-Saharan Africa (SSA) and Brazil (BRA). As shown in Figure $12 \mathrm{a}$, in the case of wheat, a major increase or decrease in production in these regions is generally triggered by changes in yields (Annex 1 ) rather than by global price variation (Figure 11b), which might be a consequence of an inelastic supply. Canada presents the most significant variability in production related to RCP 4.5, with the direction of the effects governed by carbon fertilisation (i.e., $-9 \%$ in the IPSL projection without the $\mathrm{CO}_{2}$ effects and $+13 \%$ in the HADGEM2 scenario with the $\mathrm{CO}_{2}$ effects). In contrast, in the case of the EU, we observe that the increase in production is associated to RCP 4.5, whereas the decrease is driven by the RCP 8.5, irrespective of carbon fertilisation. 
In the case of maize, the key exporters in the world are the USA, Argentina and Brazil. The main importers that we identified are Other South and Central America (OSA) -excluding Brazil and Argentina -, SEA and MENA. Although the EU is not ranked among the main maize traders, we include it in the analysis as our focus is the EU. As in the case of wheat, maize production also appears to be more influenced by changes in crop yields than by global prices (Annex 1 and Figure 11b), with Argentina, the USA, and EU-28 showing the largest variability in production (Figure 12b). While Argentina presents substantial increases in production up to $11 \%$ driven by the RCP 8.5 , the EU-28 exhibits a notable decline in maize production in all the scenarios analysed.

With regard to soybean, the main exporters are the USA, Brazil and Argentina, whereas the major importers are the China, EU-28 and SEA. As illustrated in Figure 12c, the extreme changes are typically observed under RCP 4.5, except in Argentina and SEA where the highest changes are driven by RCP 8.5. Taking into account yield changes (Annex 1), these are significantly higher in the case of Argentina and USA when carbon fertilisation effects are considered. This suggests that there is a price-related adjustment in production (Figure 11b) since the world soybean market price increase when $\mathrm{CO}_{2}$ effects are disregarded.

In the case of rapeseed, Canada, EU-28 and Australia and New Zealand are the main exporters, whereas China, EU-28 and SEA are the main importers. Figure 12d highlights that rapeseed production in Canada increases most when carbon fertilisation is not considered even though there are major increases in yields observed in scenarios with $\mathrm{CO}_{2}$ effects. This could be explained by taking into account changes in market prices, as illustrated in Figure 11b, where rapeseed prices rose when $\mathrm{CO}_{2}$ effects are not taken into account. China presents positive changes in rapeseed production in all scenarios, with the largest variations observed under RCP 4.5. In contrast, ANZ shows negative effects in all scenarios, with the extreme variations led by RCP 8.5 .

Results show that global impacts of climate change on production are unequally distributed across regions around the globe and are not only determined by regional changes in yields, but also by global price variations. Hence, the analysis at disaggregated level illustrates the negative impacts in some regions, which experience a reduction in production even when carbon fertilisation is considered (e.g., wheat in Australia and New Zealand and maize in Brazil). In addition, the effects of prices lead to reductions in production, despite climateinduced positive yield changes (e.g., soybean in Brazil). Whilst the production of wheat and 
maize, considered staple crops, followed the pattern of regional changes in yields, soybean and rapeseed production vary significantly with global prices.
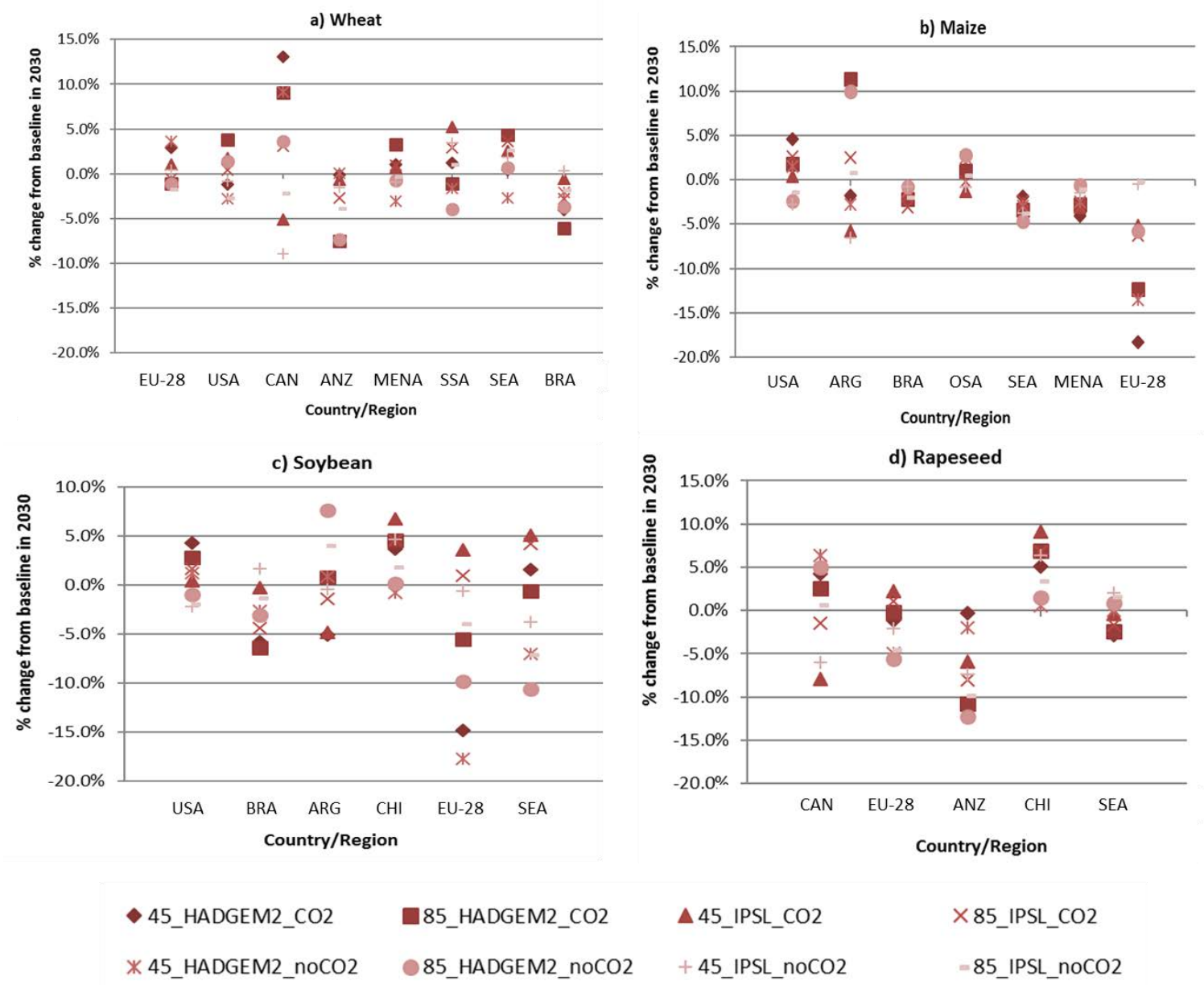

Figure 12: Production changes for the major country/region traders of a) wheat, b) maize, c) soybean and c) rapeseed in 2030 under different simulation scenarios (\% change relative to baseline values by 2030). Country/Regions: European Union (EU-28), United States (USA), Canada (CAN), Australia and New Zealand (ANZ), Middle East and North Africa (MENA), Sub-Saharan Africa (SSA), South East Asia (SEA), Argentina (ARG), Brazil (BRA), Other South and Central America (OSA), China (CHI). Source: CAPRI model.

\subsubsection{The role of trade adjustments}

To illustrate how trade adjustments counterbalance the effects of climate change on production, we concentrate on the wheat trade, considering the EU and its trading partners. The analysis is focused for one GCM, HADGEM2, with and without $\mathrm{CO}_{2}$ effects, for a 4.5 and $8.5 \mathrm{RCP}$, since it highlights sizeable variations in global production (Figure 11a).

As explained, wheat production in the EU increases under RCP 4.5 with and without $\mathrm{CO}_{2}$ effects and decreases for RCP 8.5 (Figure 12a). As observed in Figure 13, increases in 
production leads to import increases, whilst exports are reduced, especially under scenarios that consider carbon fertilisation. This marked decline in wheat exports is related to a drop in the price of this product in scenarios considering $\mathrm{CO}_{2}$ effects (Figure $12 \mathrm{~b}$ ), but also to an increase in wheat demand. Therefore, a significant rise is observed in the use of wheat for animal feed, which varies between $4 \%$ and $16 \%$ for all scenarios compared to the baseline, whereas human consumption increases by only $0.01-0.06 \%$. This change in wheat demand is linked to maize demand since wheat partially substitutes maize, whose production in the EU is negatively affected by climate change (Figure 14).

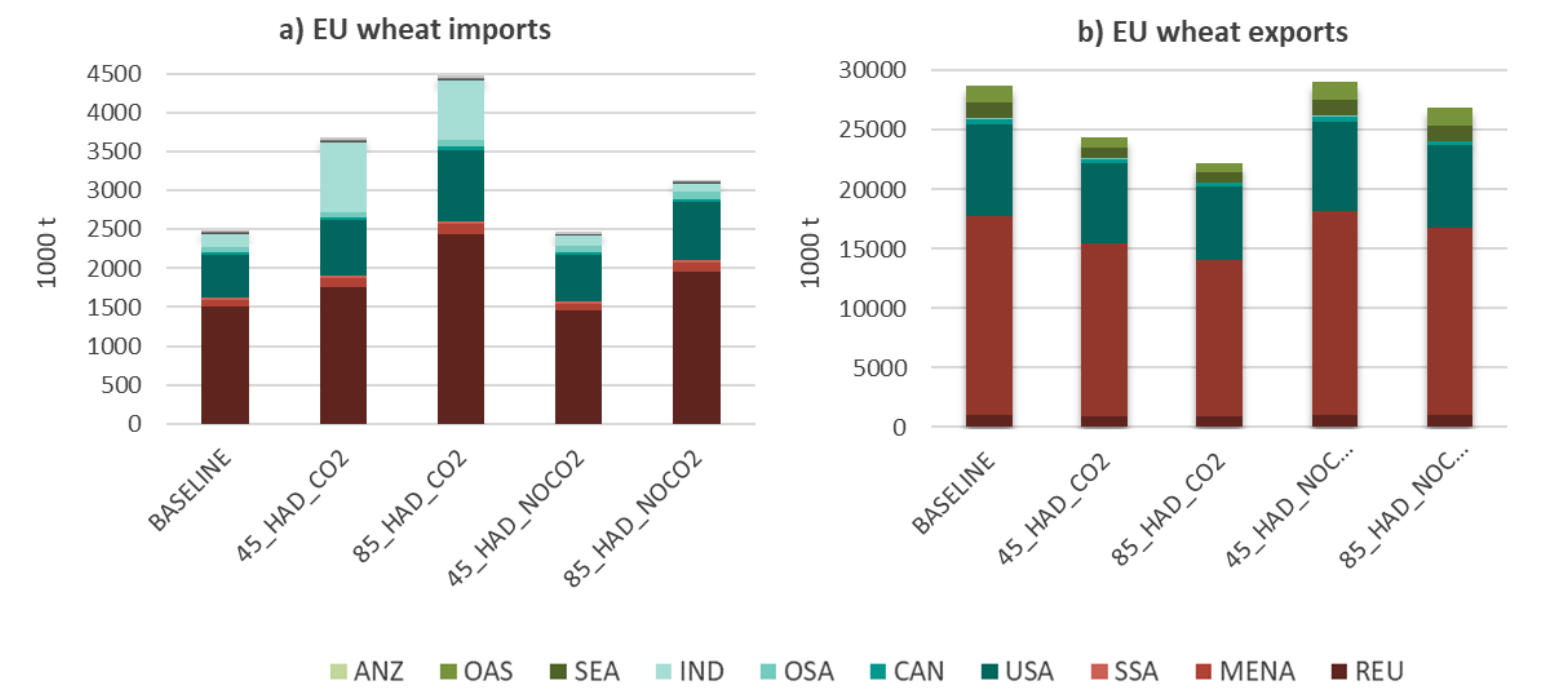

Figure 13: Wheat trade in the European Union in 2030 by trading partner under different simulation scenarios: a) imports and b) exports. Country/Regions: Australia and New Zealand (ANZ), Other Asia (OAS), South East Asia (SEA), India (IND), Other South and Central America (OSA), Canada (CAN), United States (USA), Sub-Saharan Africa (SSA), Middle East and North Africa (MENA), Rest of European Union (REU). Values in thousand tons. Source: CAPRI model. 


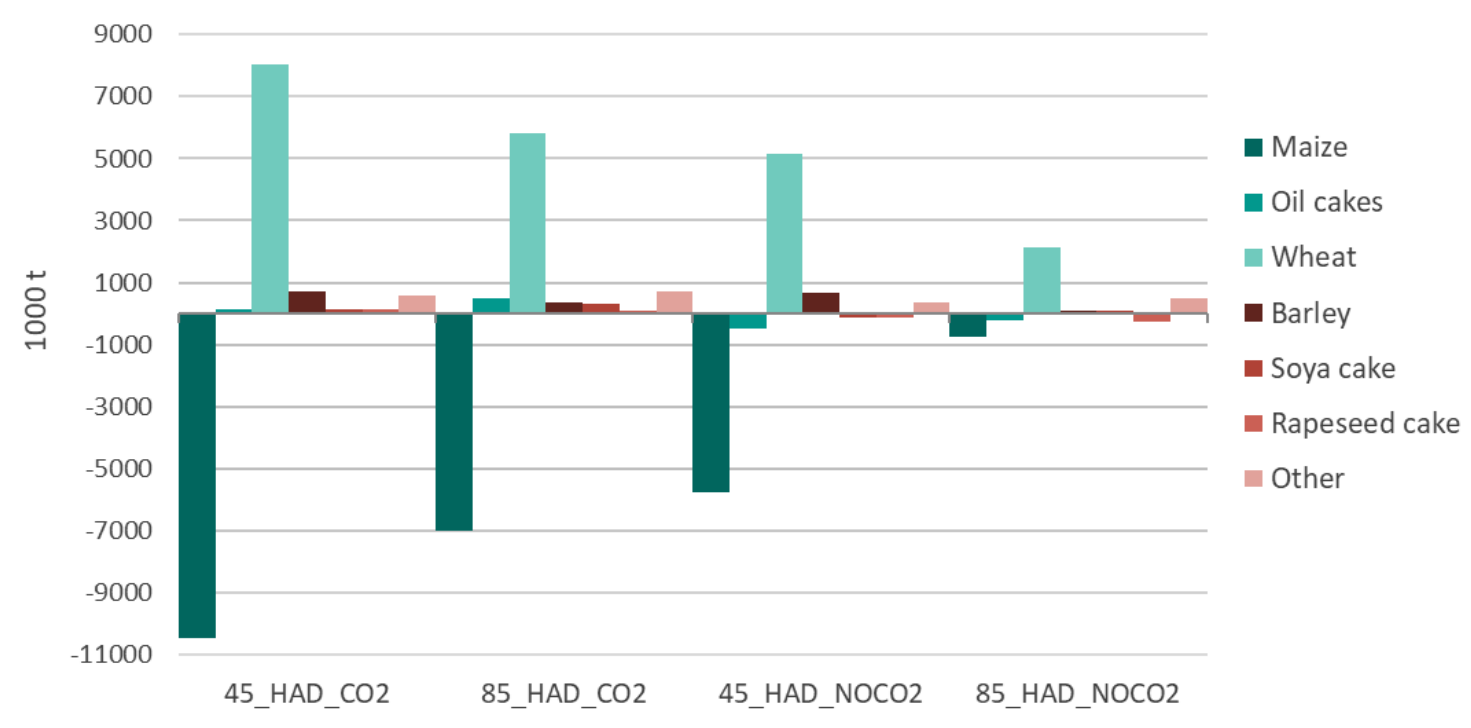

Figure 14: Feed use in European Union by product in 2030 under different simulation scenarios (absolute change relative to baseline by 2030). Values in thousand tons. Source: CAPRI model.

In response to the increase in feed demand, the EU-28 increases wheat imports and reduces exports (Figure 13). The significant decline in exports from EU-28 to MENA and SSA is compensated mainly by an increase in imports in these regions from Canada (Annex 1).

\subsection{Understanding the WEF nexus challenges}

\subsubsection{FCM Outcomes}

The 11 individual maps drawn by stakeholders comprised 206 variables that, after data processing, were aggregated into 35 variables. Individual maps included an average number of 19 variables, which when grouped resulted in 14 variables on average. Most mentioned variables were climate change (climate change aggregates the variables climate, temperature, precipitation, extreme events, droughts and floods) and water availability, which were presented in all of the 11 maps, followed by energy cost and food production depicted in ten and nine maps, respectively.

Table 3 summarises calculated matrix indices for the individual maps (average values) and of the group map. The average number of connections is 25 , leading to an average density index of 0.03 . The group map gathers all of the variables and has a higher number of connections ( $C$ $=209)$ and density index $(D=0.17)$. The larger number of connections leads to a lower number of transmitter $(T)$ and receiver $(R)$ variables in the group map, where most variables were 
ordinary. Therefore, the complexity index $(\mathrm{R} / \mathrm{T})$ is higher in the individual maps than in the group map.

Table 3: Individual and group map indices (mean and standard deviation).

\begin{tabular}{lll}
\hline Index & Individual Maps & Group Map \\
\hline Number of maps & 11 & 1 \\
Number of variables (N) & $14 \pm 2.72$ & 35 \\
Number of connections (C) & $25 \pm 9.40$ & 209 \\
$\mathrm{C} / \mathrm{N}$ & $1.81 \pm 0.59$ & 5.97 \\
Density & $0.03 \pm 0.02$ & 0.17 \\
Number of transmitter variables (T) & $2.55 \pm 2.21$ & 2 \\
Number of receiver variables (R) & $2.64 \pm 2.01$ & 1 \\
Number of ordinary variables & $8.82 \pm 2.93$ & 32 \\
Complexity (R/T) & $1.27 \pm 1.57$ & 0.5 \\
\hline
\end{tabular}

Source: Own elaboration.

Figure 15 visualises the group map, where circles symbolise concepts of the system and lines reflect causal relationships between concepts (the group map was represented using the Pajek software ${ }^{8}$. The colour of the circle refers to the different sectors, while the size reflects the centrality of the variable within the system. The most central variables were water availability, climate change, food production, irrigated agriculture, energy cost, socioeconomic factors (socioeconomic factors aggregate economic development, job generation, GDP growth, equitable distribution of wealth, change in the structure of land ownership, population settlement), irrigation water use, environmental conservation, and farm performance indicators (farm performance indicators aggregate farm income, profitability, competitiveness and sustainability, insurances costs, infrastructure modernisation).

\footnotetext{
${ }^{8}$ Pajek software - http://mrvar.fdv.uni-lj.si/pajek/
} 


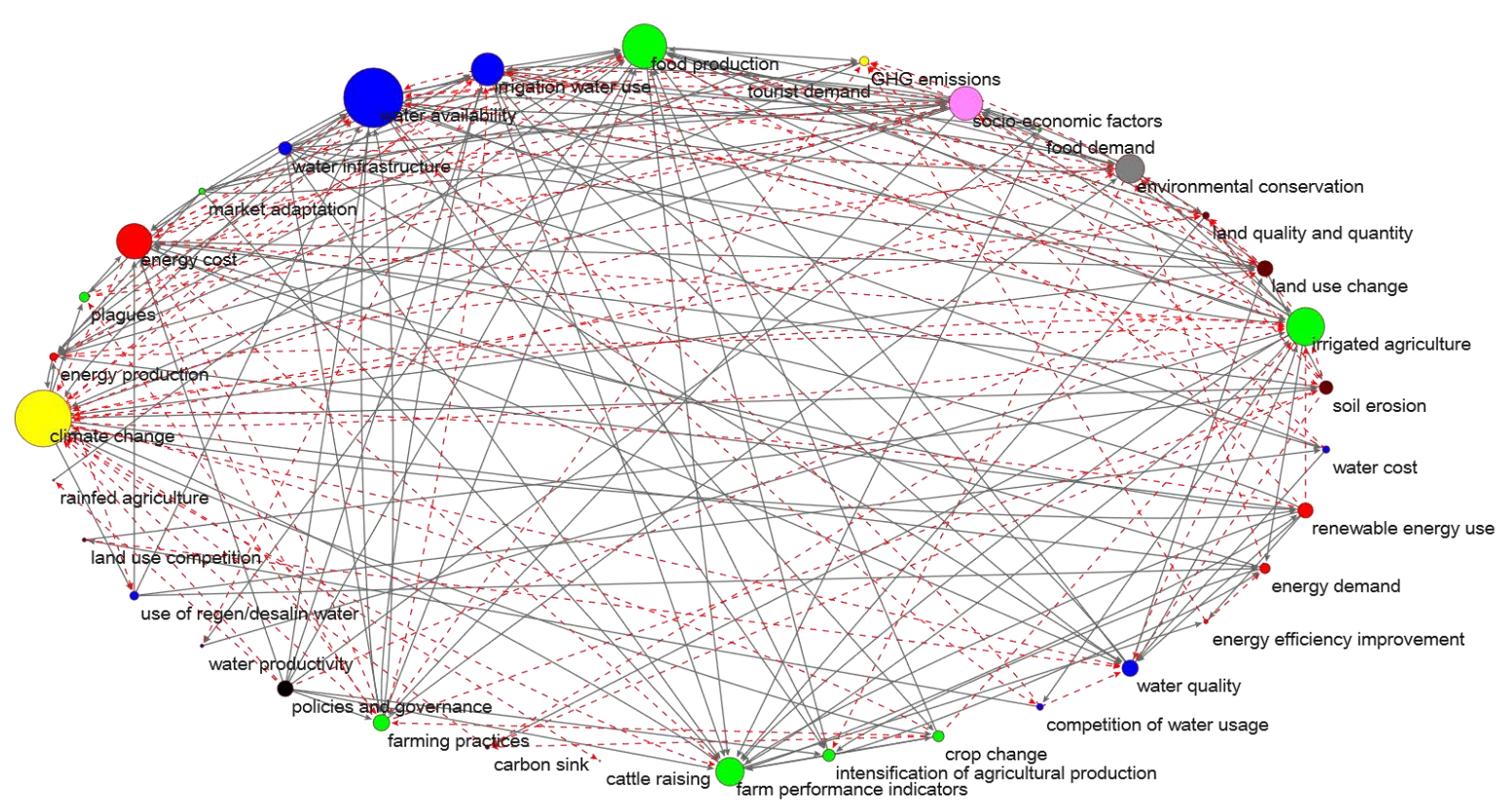

Figure 15: Visual representation of the group map. Circles represent the variables of the system, colours refer to the nexus sector (blue for water, red for energy, green for agriculture, yellow for climate, pink for socioeconomic aspects, brown for land, grey for environment and black for policies and governance) and size depicts centrality. Solid grey lines depict positive casual relationships while dotted red lines illustrate negative causal relationships. Source: Own elaboration.

As highlighted in Figure 16, most of the variables are ordinary; only policies and governance and water infrastructures were exclusively transmitter variables, while cattle raising was an entirely receiver variable. Among the most important variables in the map, climate change, water availability and energy cost have the highest outdegree, meaning that those variables are highly influencing other variables. In contrast, variables with the highest indegree, and therefore significantly affected by other variables, are food production, socio-economic factors, irrigated agriculture, environmental conservation and farm performance indicators.

Figure 17 visualizes the interconnections among the most central variables in the group map. As observed, the variables climate change, water availability and food production are highly connected to other variables, while farm performance indicators and environmental conservation have fewer connections but bear greater weights. Food production can be distinguished by the height number of incoming connections, which determines its high indegree. Looking at the type of interrelationship, the importance of energy cost and climate change are highlighted by the number of negative outgoing connections. 


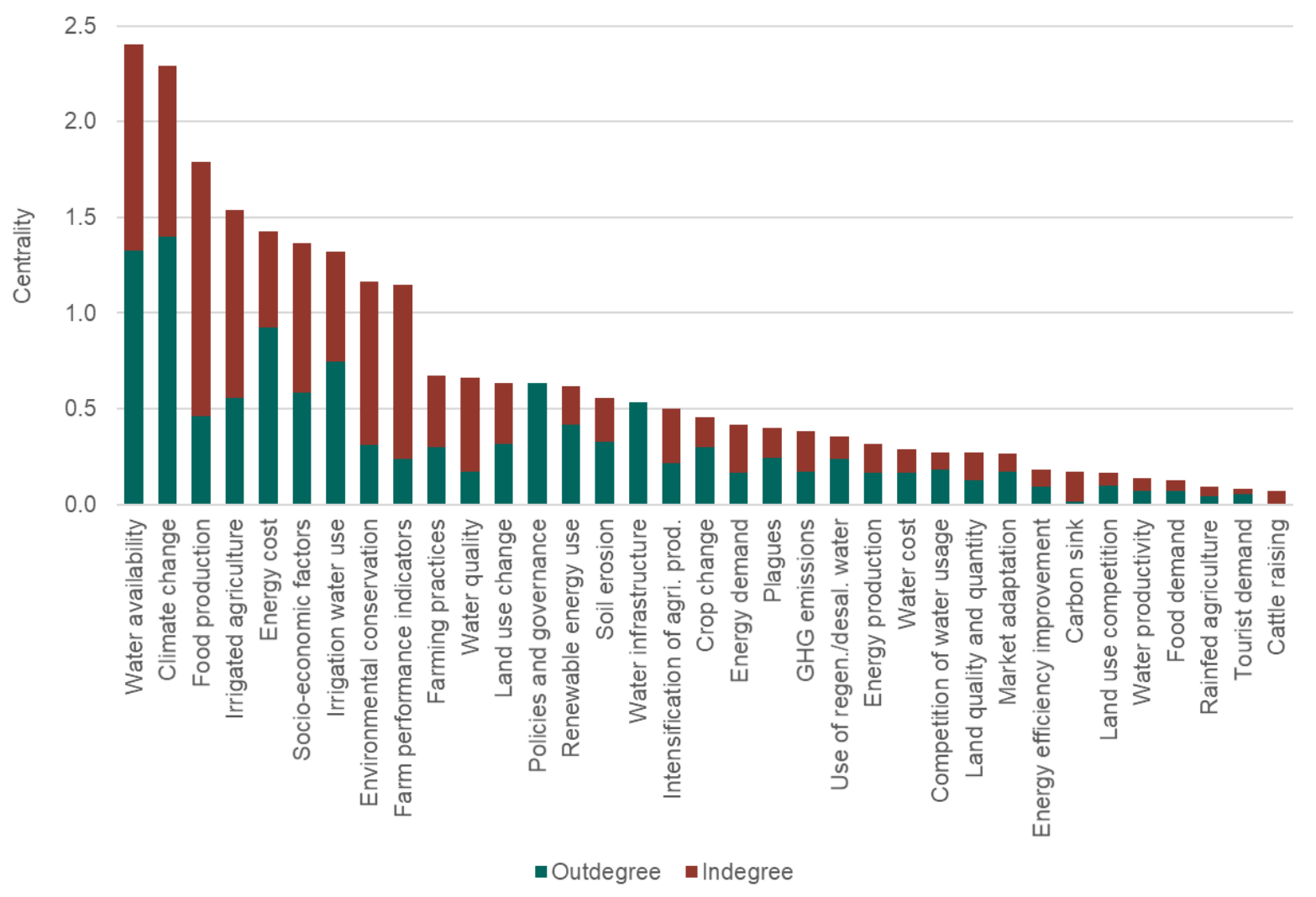

Figure 16: Importance of variables in the group fuzzy cognitive mapping according to their centrality, represented as the sum of the outdegree and indegree. Source: Own elaboration.

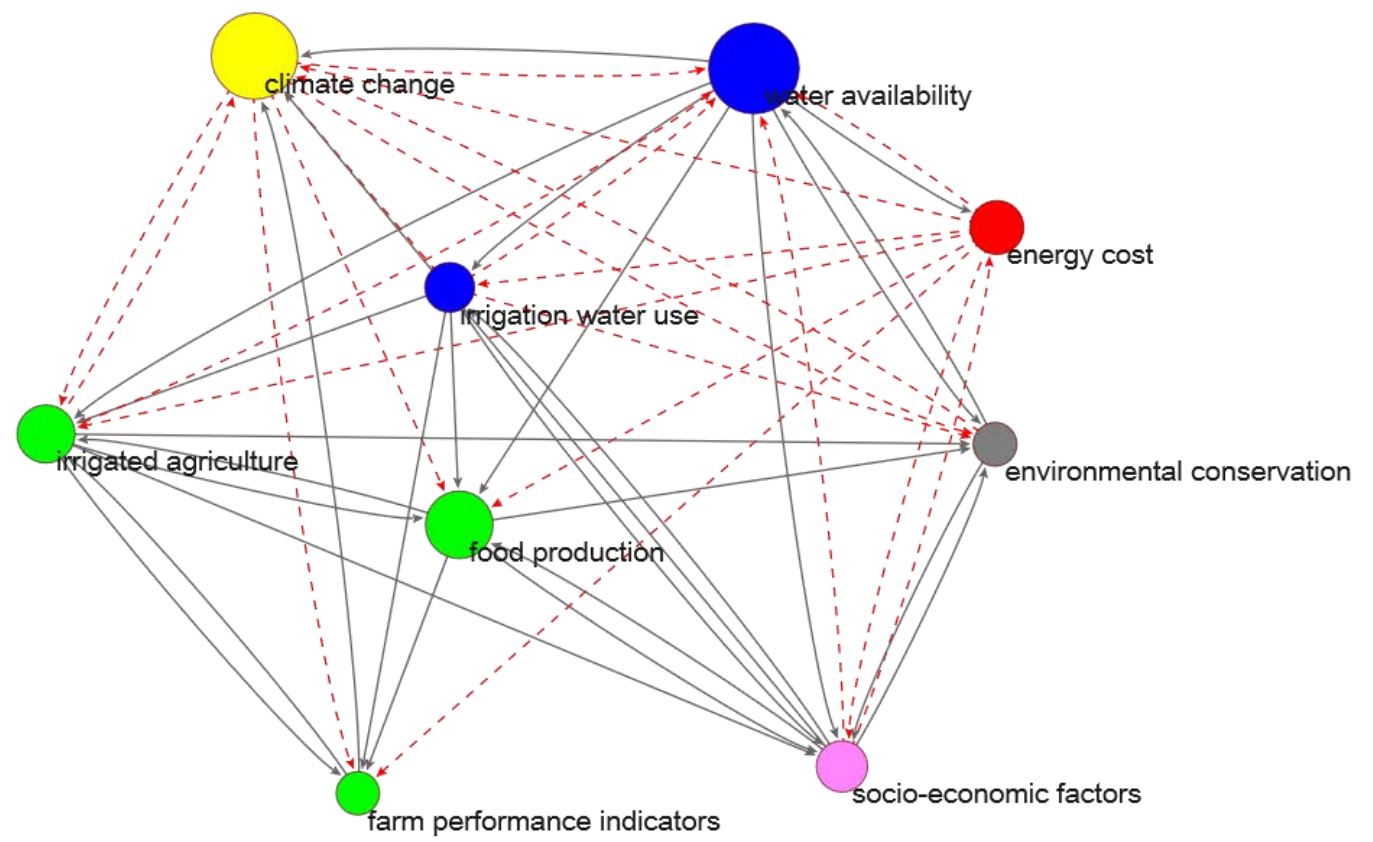

Figure 17: Visual representation of a subset of the group map. The nine variables with centrality higher than 1 are represented. Grey solid lines for positive and red dotted lines for negative connections. Source: Own elaboration. 


\subsubsection{Scenario Simulations}

Figure 18 represents the results from the steady state calculation (obtained after 20 iterations) for all of the variables derived from the group FCM. The variables with the highest initial value are farm performance indicators, food production, irrigation water use and energy cost which suggest that these variables significantly influence the WEF nexus in the current situation. In contrast, the variable with the lowest initial value is water availability, which reflects the high pressure on water resources in Andalusia.

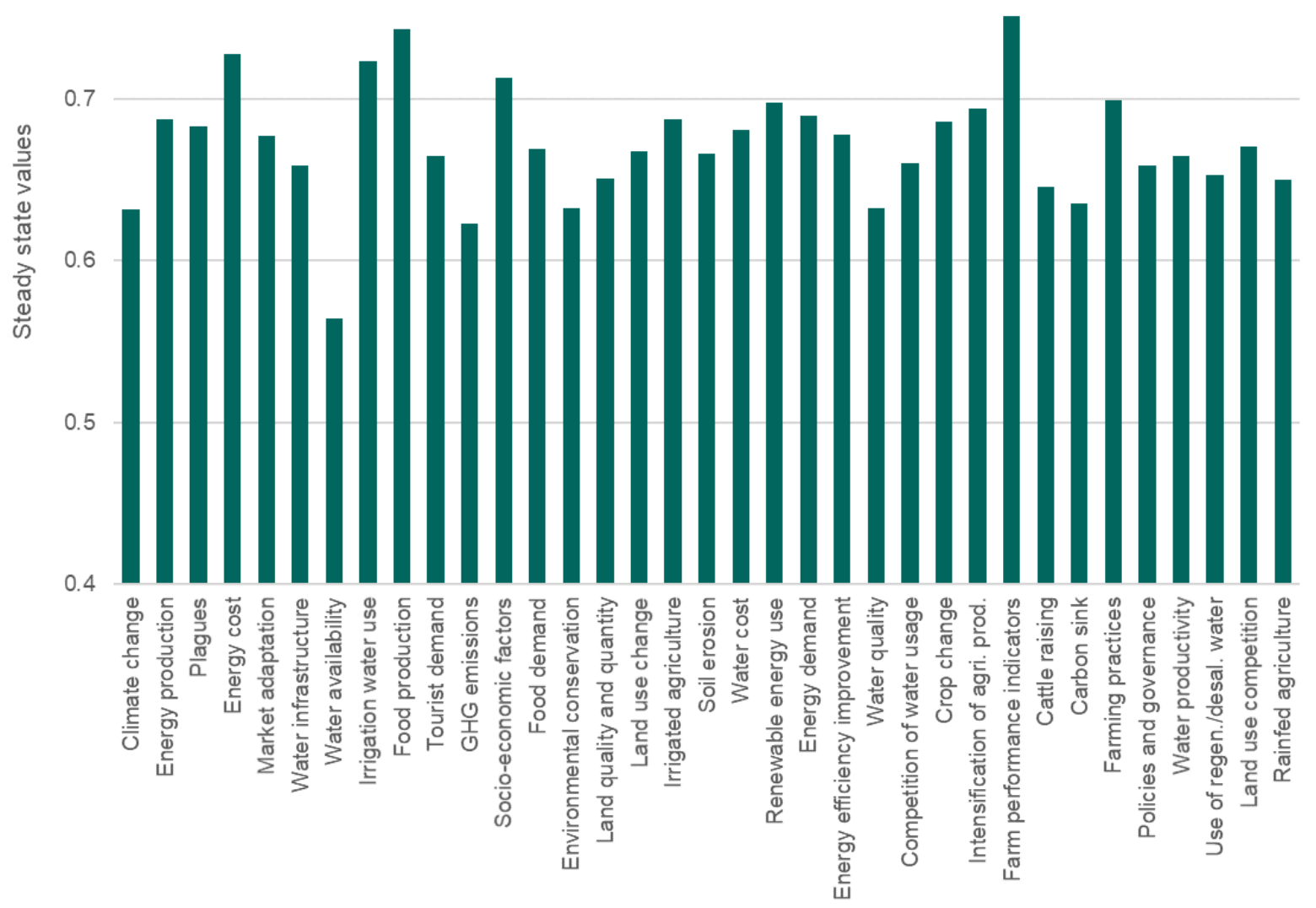

Figure 18: Steady state. Source: Own elaboration.

As shown in Figure 19, results from the climate change scenario (Scenario 1) highlight that an improvement in farming practices and the promotion of renewable energy use trigger a reduction in GHG emissions and contribute to tackling climate change. Significant effects are also observed in the variables soil erosion and environmental conservation. Food production and farm performance indicators are also positively affected as a result of better farming practices. A negative relative change in one variable does not always imply a negative impact 
on the system, as can be observed for the variables climate change, GHG emissions, and soil erosion.

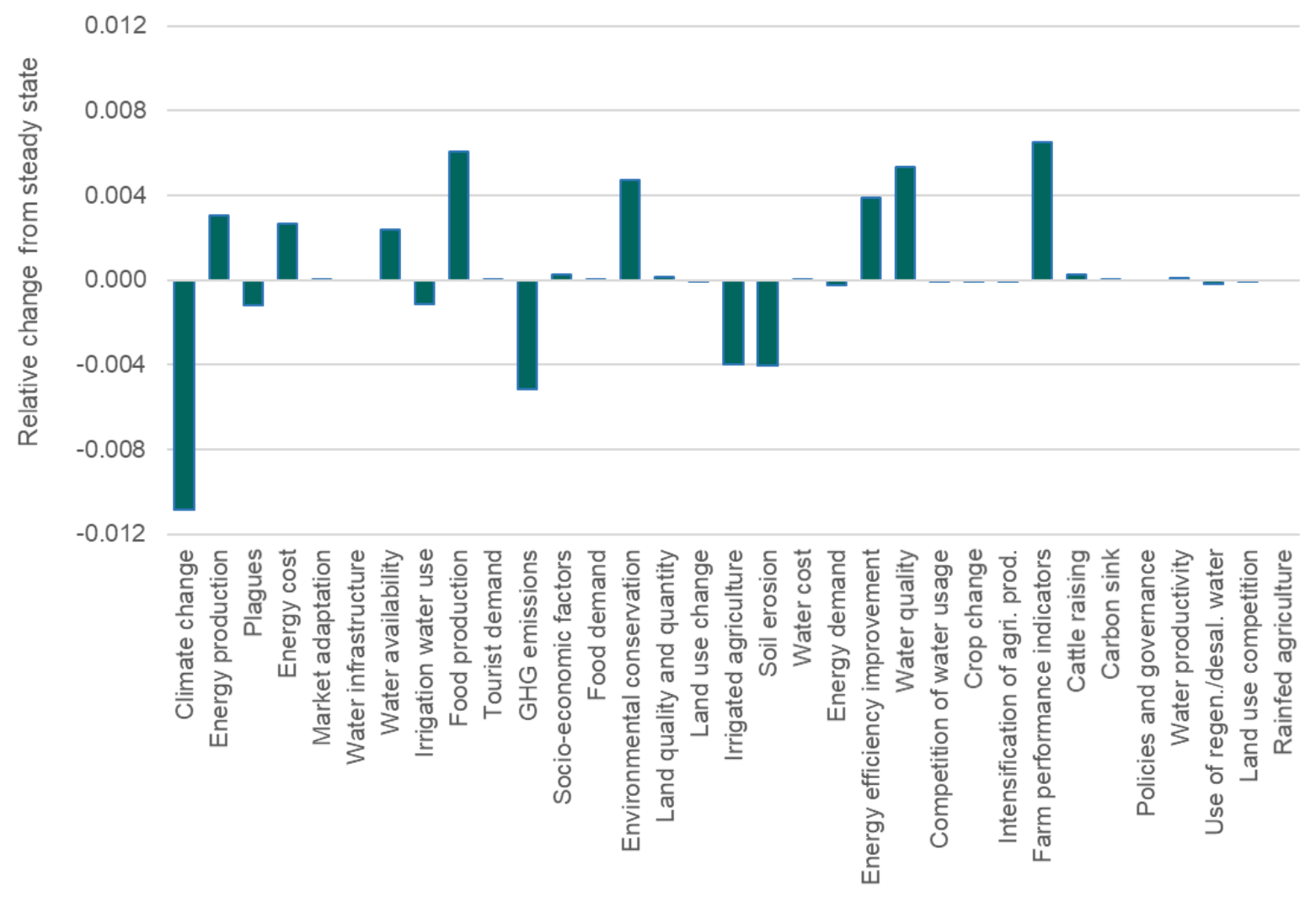

Figure 19: Climate change mitigation scenario simulation (absolute change from steady state). Source: Own elaboration.

With regards to the sustainable water management scenario (Scenario 2), as observed in Figure 20 , the improvement in water infrastructures and water quality would have a positive effect on water availability and, thus, on irrigated agriculture and food production. Consequently, farm performance indicators would be positively affected. Nevertheless, these measures would imply a rise in energy costs as well as further environmental deterioration. 


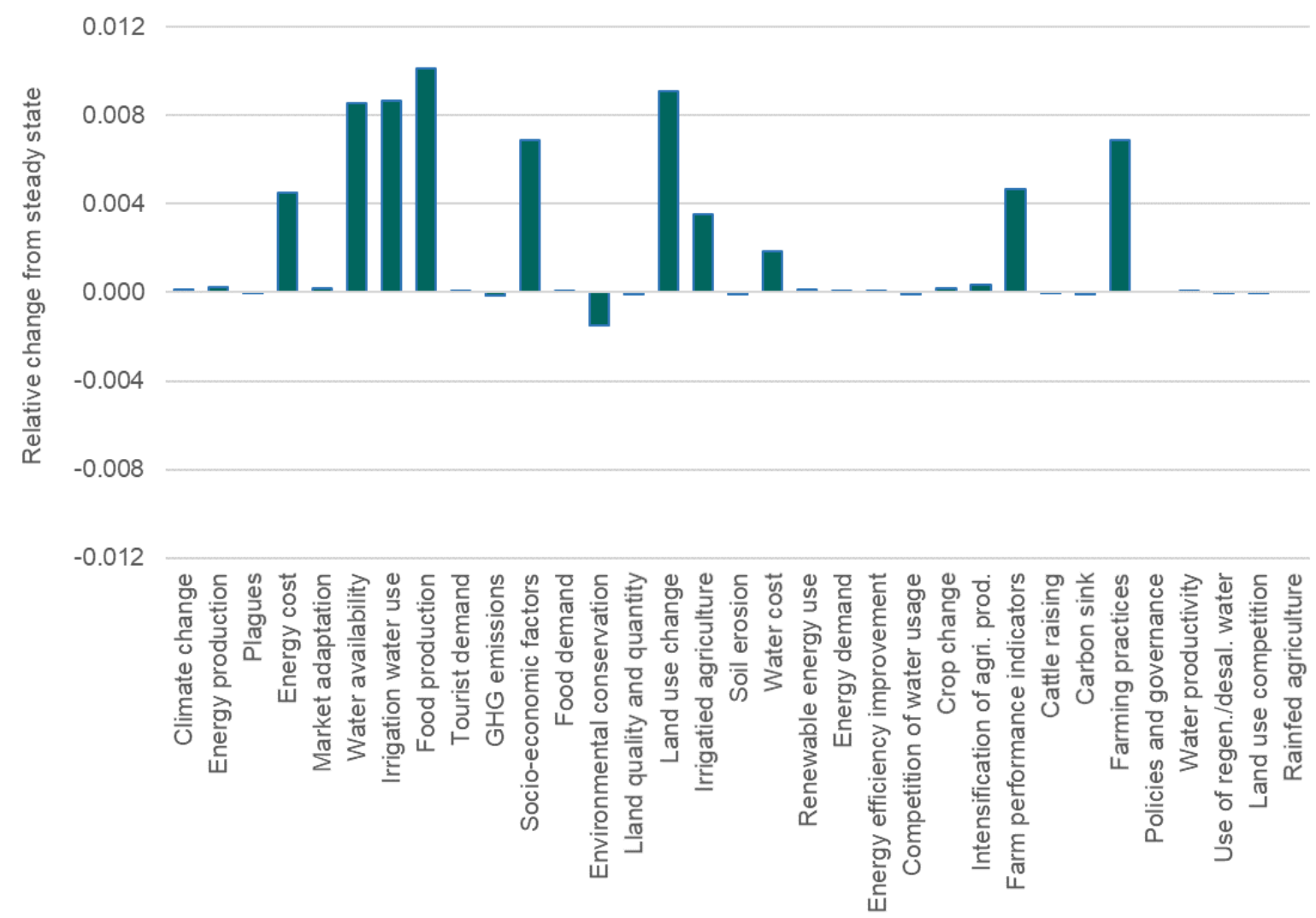

Figure 20: Sustainable water management scenario simulation (absolute change from steady state). Source: Own elaboration.

\subsection{Disentangling key water-related drivers of future agricultural development}

\subsubsection{Scenario results}

The results from CAPRI-Water show that the impacts of climate change on water availability for agriculture as well as future changes in irrigation efficiency and irrigation costs, will significantly affect the agricultural sector in Andalusia. Table 4 summarises outcomes from the reference, the worst-case and best-case scenarios for rain-fed land, irrigated land, irrigation water use and income for main crops in Andalusia over the horizon 2050. 
Table 4: Results from the reference, worst-case and best-case scenarios for rain-fed land, irrigated land, irrigation water use and income for main crops in Andalusia in 2050. The values are presented in absolute terms for the reference scenario and percentage change from the reference for the worstcase and best-case scenarios. The units are 1000 ha for land, million $\mathrm{m}^{3}$ for water use and million euro for income.

\begin{tabular}{|c|c|c|c|c|}
\hline & & \multicolumn{3}{|c|}{ Simulated scenarios } \\
\hline & & Reference $\left(X^{0}\right)$ & Worst-case $\left(\mathbf{X}^{1}\right)$ & Best-case $\left(X^{2}\right)$ \\
\hline Utilized & Rain-fed land & 4054.9 & 2.3 & -3.1 \\
\hline agricultural & Irrigated land & 849.0 & -10.4 & 14.1 \\
\hline \multirow[t]{2}{*}{ area } & Irrigation water use & 2938.8 & -5.5 & 8.3 \\
\hline & Income & 7297.93 & -1.1 & 1.2 \\
\hline \multirow[t]{4}{*}{ Cereals } & Rain-fed land & 467.0 & 1.4 & -10.1 \\
\hline & Irrigated land & 13.0 & -48.9 & 340.2 \\
\hline & Irrigation water use & 49.3 & -28.4 & 268.5 \\
\hline & Income & 286.53 & -0.9 & 4.7 \\
\hline \multirow[t]{4}{*}{ Oilseeds } & Rain-fed land & 225.3 & 1.4 & -1.2 \\
\hline & Irrigated land & 26.6 & -9.8 & 8.9 \\
\hline & Irrigation water use & 117.57 & -6.7 & 5.1 \\
\hline & Income & 177.55 & -1.9 & 1.8 \\
\hline \multirow[t]{4}{*}{ Vegetables } & Rain-fed land & - & - & - \\
\hline & Irrigated land & 59.39 & -0.1 & 0.1 \\
\hline & Irrigation water use & 371.44 & 4.1 & -4.0 \\
\hline & Income & 1707.60 & -0.1 & 0.1 \\
\hline \multirow[t]{4}{*}{ Citrus Fruits } & Rain-fed land & 30.2 & 9.9 & -9.2 \\
\hline & Irrigated land & 74.6 & -4.3 & 4.0 \\
\hline & Irrigation water use & 535.91 & -0.6 & 0.0 \\
\hline & Income & 412.46 & -3.3 & 3.1 \\
\hline \multirow[t]{4}{*}{ Other fruits } & Rain-fed land & 69.93 & 0.0 & 0.0 \\
\hline & Irrigated land & 14.32 & -1.0 & 0.8 \\
\hline & Irrigation water use & 89.22 & 3.2 & -3.2 \\
\hline & Income & 744.24 & -0.3 & 0.3 \\
\hline \multirow[t]{4}{*}{ Olives for oil } & Rain-fed land & 1496.1 & 5.1 & -4.7 \\
\hline & Irrigated land & 613.6 & -12.0 & 11.1 \\
\hline & Irrigation water use & 1605.98 & -9.2 & 7.3 \\
\hline & Income & 1646.03 & -3.2 & 2.9 \\
\hline
\end{tabular}


Under the worst-case scenario $\left(\mathrm{X}^{1}\right)$, CAPRI-Water anticipates a $10.4 \%$ decrease in the total irrigated land, which particularly affects cereals and olives for oil and, to a lesser extent, oilseeds. In contrast, irrigated land allocated to vegetables remains virtually unchanged and irrigated land for citrus and other fruits decreases moderately. In line with the decline in irrigated area, the total irrigation water use falls by $5.5 \%$. Whereas irrigation water use decreases significantly for most of the crops, citrus fruits experience a limited decline, and vegetables and other fruits, show an increase in water use.

Looking at the best-case scenario results $\left(\mathrm{X}^{2}\right)$, the total irrigated land is projected to increase by $14.1 \%$ and irrigation water use by $8.3 \%$. The largest effects are observed for cereals that undergo an expansion in irrigated land over $300 \%$, accompanied by a similar increment in irrigation water use.

The total agricultural income is expected to range between $-1 \%$ and $1 \%$, with notable differences among crops. Income from cereals, citrus fruits and olives for oil vary around 3\%, while remaining unchanged for vegetables and other fruits both in the best-case and worstcase scenarios.

\subsubsection{Sensitivity Analysis}

The results of the sensitivity analysis for total, cereals and citrus fruits irrigated land to the different drivers are presented in Figure 21. The overall variation in irrigated land is decomposed into sensitivity indices that depict total, individual and interaction effects of each driver, expressed as a percentage difference from the reference scenario. The left side of the figure represents sensitivity indices when drivers shift from the reference value to the worstcase scenario $\left(\mathrm{X}^{1}\right)$ and the right side depicts sensitivity indices when values change to the bestcase scenario $\left(X^{2}\right)$.

The total irrigated land decline in $X^{1}$ and expansion in $X^{2}$ is induced mainly by individual effects of irrigation costs. The sensitivity to irrigation efficiency is negligible, whereas the variation in the driver water availability appears not to have an effect. The observed pattern in total irrigated land is reproduced when looking at crop-specific results, yet the magnitude of effects is very different. While increased costs lead to a reduction in citrus irrigated land by around $4 \%$ in scenario $X^{1}$, variation in cereals irrigated land is around $50 \%$. This change is even higher in scenario $\mathrm{X}^{2}$, where the reduction in costs induces a large increase in irrigated land allocated to cereals. 
$X^{0} \rightarrow X^{1}$
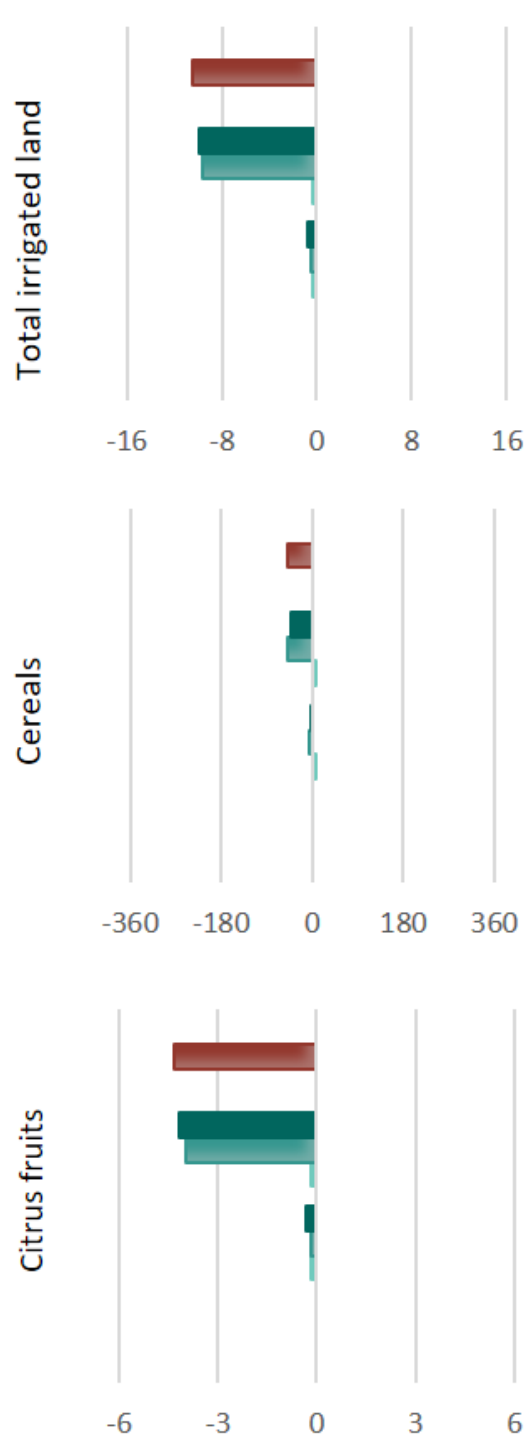

$x^{0} \rightarrow x^{2}$

Total change

Irrigation costs

Irrigation efficiency

Water availability

Total change

Irrigation costs

Irrigation efficiency

Water availability

$-360 \quad-180$

$\begin{array}{lll}0 & 180 & 360\end{array}$

Total change

Irrigation costs

Irrigation efficiency

Water availability
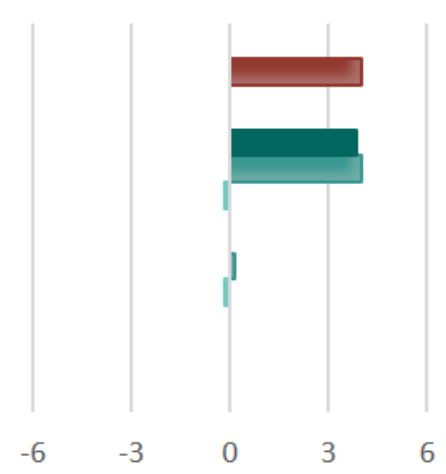

Figure 21: Sensitivity of irrigated agricultural land (total, cereals and citrus fruits) to scenario drivers when shifting from the reference to the worst-case scenario (left) and to the best-case scenario (right). Results are presented for total irrigated land, cereals and citrus fruits. The total change in irrigated land is decomposed in changes due to total, individual and interaction effects of each driver. The results are presented as \% change from the reference scenario. Source: Own elaboration.

Sensitivity of total, cereals and citrus fruits irrigation water use to the different drivers is reported in Figure 22. In this case, the results are driven both by irrigation costs and irrigated efficiency. These drivers lead to inverse changes in irrigation water use and thereby counteract each other. The magnitude of sensitivity to irrigation costs and irrigation efficiency varies across crops. In the case of citrus fruits, the increase and decrease in water use in scenarios 
$\mathrm{X}^{1}$ and $\mathrm{X}^{2}$, respectively, are around $5 \%$. Variations are driven by both irrigation costs and irrigation efficiency to a similar extent, countering their effects and triggering limited changes in water use. With regard to cereals, changes in irrigation water use are in the order of $300 \%$ and stem mostly from changes in irrigation cost.
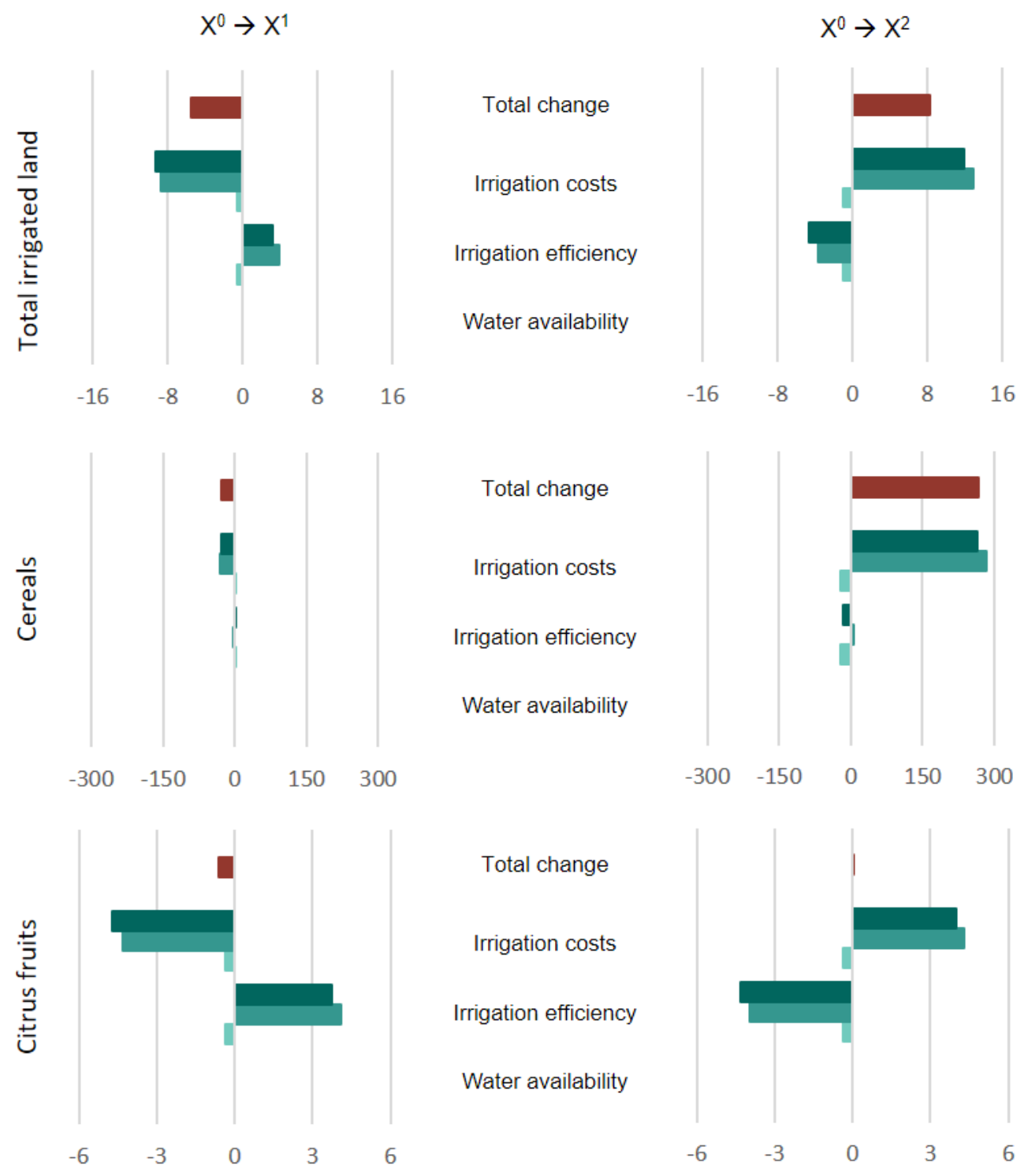

Figure 22: Sensitivity of irrigation water use (total, cereals and citrus fruits) to scenario drivers when shifting from the reference to the worst-case scenario (left) and to the best-case scenario (right). Results are presented for total irrigated land, cereals and citrus fruits. The total change in irrigation water use is decomposed in changes due to total, individual and interaction effects of each driver. The results are presented as \% change from the reference scenario. Source: Own elaboration. 
In terms of agricultural income, as observed in Figure 23, variations in results are driven essentially by irrigation costs. The increase in costs in scenario $X^{1}$ causes a decline in the total agricultural income in the region, while the decrease in scenario $X^{2}$ leads to an increased income. Total income variations in both scenarios are around $1 \%$, whilst observed changes for cereal and citrus fruits income are in the order of $3 \%$.

$X^{0} \rightarrow X^{1}$
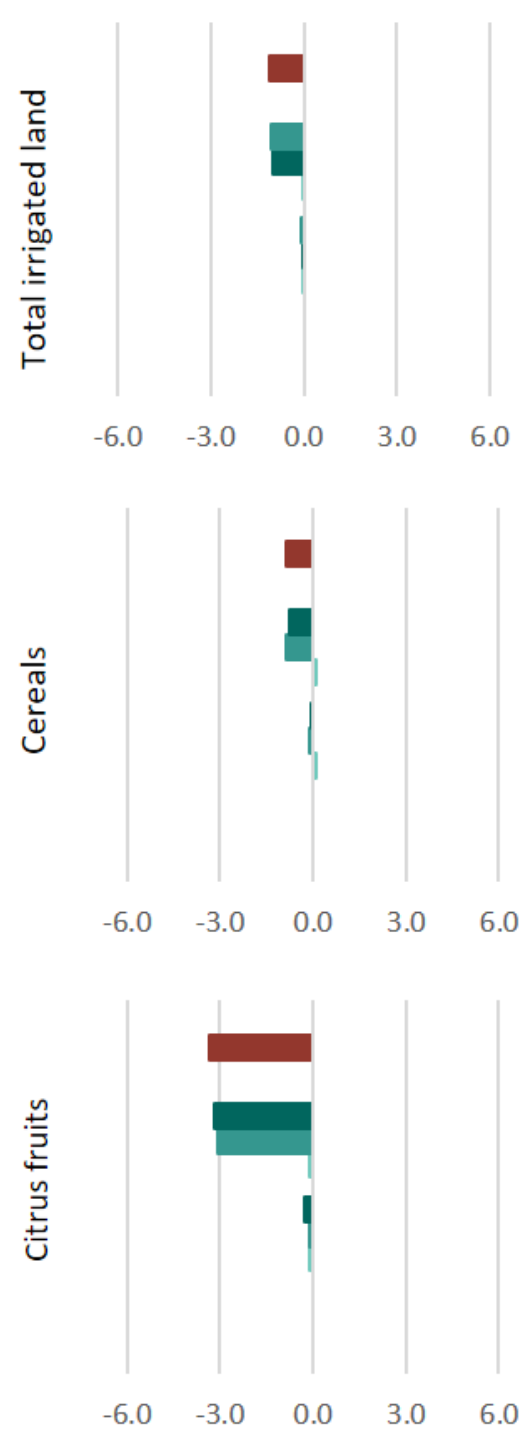

$X^{0} \rightarrow X^{2}$

Total change

Irrigation costs

Irrigation efficiency

Water availability

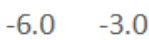

$0.0 \quad 3.0$

6.0

Total change

Irrigation costs

Irrigation efficiency

Water availability

$-6.0-3.0$

$\begin{array}{lll}0.0 & 3.0 & 6.0\end{array}$

Total change

Irrigation costs

Irrigation efficiency

Water availability
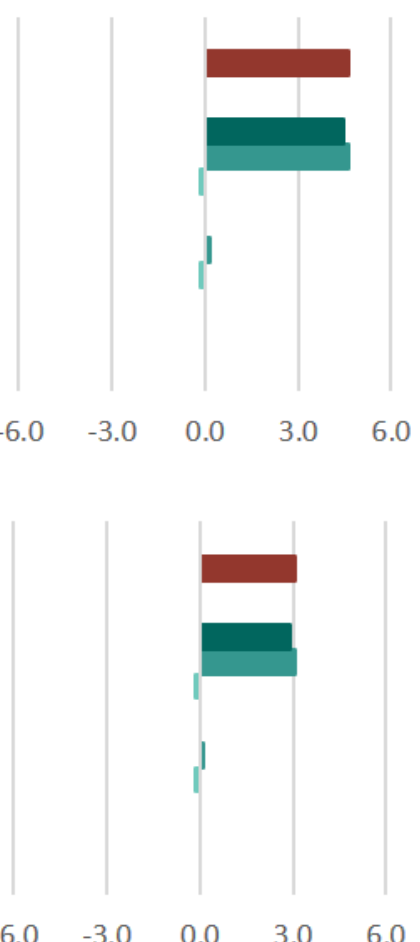

Interaction effect

Figure 23: Sensitivity of income (total, cereals and citrus fruits) to scenario drivers when shifting from the reference to the worst-case scenario (left) and to the best-case scenario (right). The total change in income is decomposed in changes due to total, individual and interaction effects of each driver. The results are presented as \% change from the reference scenario. Source: Own elaboration. 


\section{Discussion}

The methodological framework applied in this research combines the implementation of a bio-economic modelling approach built on the CAPRI model, a participatory approach underpinned on FCM and a sensitivity analysis of CAPRI-Water results based on sensitivity analysis with finite changes, to improve knowledge on the interconnections between agriculture and environment at different scales from the global and European to the regional level in Andalusia (Spain).

The bio-economic modelling approach performed has enabled us to explore the effects of climate change on agricultural markets both globally and for the main traders, with a focus on the EU over the horizon 2030. To account for uncertainty surrounding climate change effects, we analysed different scenarios that differ with respect to: (1) the climate projection (HadGEM2-ES and IPSL-CM5A-LR), (2) RCP (4.5 and 8.5) and (3) the influence of carbon fertilisation effects.

Similar to Deryng et al. (2014) and Rosenzweig et al. (2014), we also observe that the impacts of climate change on crop yields varied widely across regions and crops depending on RCPs and carbon fertilisation effects. The RCP determine the magnitude of the climate change impacts but the highest range of variation is not always related to the extreme RCP. This is because larger uncertainties for RCP 8.5 emerge at the end of the century, while in the coming decades observed differences between RCP 4.5 and RCP 8.5 are reduced (Rosenzweig et al., 2014; Wiebe et al., 2015). The carbon fertilisation effect influences the direction of impacts in such a way that, when it is not considered, yields decrease. Results show that the highest range of uncertainty corresponds to rapeseed and soybean because of the regional concentration of these productions that make these crops more sensitive to climate projections. The lowest range of uncertainty is observed for maize due to the limited response of this C4 crop to the carbon fertilisation effect. Global average yield changes hide geographical differences, showing that the effects of carbon fertilisation could counterbalance negative climate-induced productivity changes in high latitudes, yet it is not always the case in medium and low latitudes.

Changes in crop prices in response to yield changes lessen the impacts of climate change on agricultural production at global level (Nelson et al., 2010; Wiebe et al., 2015) in such a way that global changes in yields between $-8 \%$ and $+12 \%$ result in changes in production of $-1.5 \%$ to $+2.5 \%$. Focusing on the main producer regions, results show that Canada and the USA would 
be the regions most positively affected by climate change, whereas Australia and New Zealand and Brazil would be most negatively impacted. In the case of the EU, production decreases for maize, soybean and rapeseed while increasing for wheat.

The diverging effect of climate change on production across regions is counterbalanced by trade (Baldos and Hertel, 2015; Reilly and Hohmann, 1993; Tobey et al., 1992). Considering wheat production, the EU generally shows an increase in both production and consumption that leads to a reduction of exports to its main trading partners. This reduction is compensated by exports from Canada and the USA. Therefore, trade can act as an adaptation strategy to cope with climate change impacts on agriculture throughout the world.

Considering the global nature of agricultural and food markets, economic impacts of climate change on agriculture need to be assessed at the world level. Nevertheless, both the climate effects and the policy-making process are country- and region-specific, which suggests that impact assessments are also required at regional level (Elbehri et al., 2015). Furthermore, as agriculture is highly interconnected with other sectors, these assessments must build on systemic approaches that consider cross-sectoral connections (Hoff et al., 2011; WEF, 2011) and involve stakeholders in the process to facilitate knowledge sharing and ensure policy coherence (Lindberg and Leflaive, 2015).

Following this rationale, the implementation of a participatory approach has allowed us to gain insights into the WEF nexus in Andalusia. Through the application of the FCM methodology, we have involved decision-makers in the identification of the main nexus interlinkages, while promoting discussion and consensus building among stakeholders from different sectors. Furthermore, the exploitation of FCM model dynamics has enabled the analysis of different scenarios to improve our knowledge on the system behaviour.

Matrix indices from individual maps highlight that stakeholders perceive the nexus as a highly complex system, having more receiver than transmitter variables. These findings contrast with other FMC studies that, overall, show more transmitter variables than receivers (Özesmi and Özesmi, 2004). Notwithstanding this, in the group map, the number of these types of variables is reduced because of the increase in the number of connections. The group map presents a higher density index but lower complexity index (Vasslides and Jensen, 2016). While individual maps provide valuable information on the diversity of opinions among stakeholders, the group or social map offers a more comprehensive vision of the nexus (Gray et al., 2012) 
Stakeholders agree that climate change and water availability are key factors in the WEF nexus, as all of the maps considered them. These variables have also the highest centrality in the aggregated map, influencing significantly the behaviour of the system as drivers (highest outdegree), but also as receiver variables (highest indegree). This implies that any change in these variables (e.g., policy measure) will have a significant impact throughout the system. Food production, irrigated agriculture, environmental conservation, and farm performance indicators are also central in the system due mainly to their high indegree, indicating that these variables are very sensitive to any intervention in the system. Energy cost highlights by its outdegree and high number of negative connections, which means that changes in energy policy would have relevant impacts on the water and food sectors. Other studies in Mediterranean areas find similar nexus interlinkages (Hardy et al., 2012).

The simulation scenarios analysed in this study address the policy objectives proposed by stakeholders, which are climate change and water availability. The stakeholder priorities are consistent with the results derived from the group model, where these variables were highlighted as being the most central variables and the most important drivers in the WEF nexus.

The climate change scenario illustrates that the improvement of farming practices and the promotion of renewable energies effectively lead to a reduction of GHG emissions. Better farming practices also contribute to reducing soil erosion and improving water quality, which in turn positively influences environmental conservation. Boosting renewable energies increases energy production and energy efficiency but negatively affects irrigated agriculture. This is due to the competition for water use between irrigated agriculture and energy production, mainly hydropower. Despite the negative effect on irrigated agriculture, food production is positively affected owing to the improvement of agricultural practices and, correspondingly, farm performance indicators increase.

The sustainable water management scenario demonstrates that the improvement of water infrastructure management and the reduction of water pollution lead to an increase in water availability, which in turn causes an increase in irrigation water use (Corominas and Cuevas, 2017). A negative impact on environmental conservation is also observed in this scenario. This implies that the measures to improve sustainable water management have an opposite effect than the one intended and, therefore, do not represent an appropriate policy option to be implemented. 
The combination of both scenarios reinforces the impacts derived from each one. This is because, in this case, the measures analysed are complementary. Farming practices from Scenario 1 also have a positive effect on water management, as stakeholders consider that good farming practices reduce water use in agriculture.

Understanding challenges faced by stakeholders is fundamental to deliver policy impacts assessment relevant for decision-making (Gabber et al., 2010, Höllermann and Evers, 2017). Notwithstanding, these assessments are often based on models that attempt to represent the sector performance in a simplified manner, based on multiple assumptions that lead to uncertainties in model results, in addition to the inherent uncertainties linked to an unknown future (Walker et al., 2003). This provides evidence of the need for applying tools, such as sensitivity analysis, that contribute to strengthen the reliability of model results.

The participatory process applied in this research provided the foundation to perform a sensitivity analysis of CAPRI-Water results, which has enabled us to disentangle key waterrelated drivers of agriculture under climate change in Andalusia. Based on a reference scenario that accounts for climate-induced changes in crop productivity under RCP6, we have analysed the sensitivity of irrigated land, irrigation water use and agricultural income to shifts in three drivers: water availability for agriculture, irrigation efficiency, and irrigation costs.

Irrigated land is fundamentally driven by irrigation costs. The decline (expansion) in irrigated land arises from increased or decreased costs in the worst- and best-case scenarios, respectively. The same pattern applies to crop-specific irrigated land, although there are significant differences on the magnitude of sensitivity between crops. Citrus fruits are less sensitive to changes in costs than cereals due to higher water productivity that enable these productions to afford higher costs. These future trends are consistent with observed adjustments in cropping patterns that benefit more profitable crops in response to increased irrigation costs (Fernández García et al., 2014).

Our results indicate that water availability for agriculture does not significantly influence the agricultural landscape. This fact may arise from the underlying assumption about costs in the reference scenario (i.e., increased irrigation costs of 0.01 euro per $\mathrm{m}^{3}$ ) and denotes a high responsiveness of the model to this parameter. Furthermore, we have observed that irrigation costs are a limiting factor on irrigation in Andalusia, as highlighted by stakeholders and by other authors (Rodríguez-Díaz et al., 2011a; Fernández García et al., 2014). 
Irrigation water use is not only driven by irrigation costs but also by irrigation efficiency, which behave in opposite directions and counteract each other. A reduction in these costs boosts irrigation water use, whereas irrigation efficiency gains lower it. The sensitivity to each of these drivers depends critically on the crop. Citrus fruits are sensitive to irrigation costs and irrigation efficiency, whereas cereals are more sensitive to costs. In the best-case scenario, irrigation efficiency gains lead to a reduction in water use for citrus fruits, while cereals experience a significant increase prompted by depressed costs. In contrast, in the worst-case scenario, irrigation water use exhibits a notable decrease for cereals while a slight decline is observed for citrus fruits. Accordingly, citrus irrigation water use barely changes in the scenarios analysed, while cereal water use varies substantially. This suggests that water is allocated with priority to higher-profitability crops under resource restrictions and also that increased irrigation cost effects on water use diverge substantially among crops (García-Vila et al., 2008, Berbel et al., 2018b).

Significant variations in irrigated land and irrigation water use lead to small changes in total agricultural income in the region, which ranges between $-1.1 \%$ and $+1.2 \%$ in the worst- and best-case scenarios, respectively. This can be explained by the allocation of water to highvalue crops such as vegetables and fruits that cushion the impact on income. While most crops exhibit a decrease in water use under the worst-case scenario, vegetables and other fruits experience an increase. These results are in line with insights from stakeholders who foresee the allocation of water resources increasingly based on water productivity, which would lead to a decline in irrigated land for cereals (e.g., maize, rice) over the coming years in favour of more profitable crops such as fruits.

The sensitivity of agricultural development to the different drivers analysed offers relevant information for decision-making. Climate change is projected to impact agriculture in the region through changes in crop productivity and water availability (CEDEX, 2017; Donnelly et al., 2017). Notwithstanding, variations in irrigation costs potentially induced by future socioeconomic development (e.g., water pricing, use of non-conventional water resources such as desalinisation and water reused, evolution of energy markets, etc.) emerge as a major driver in the Andalusian agricultural sector, with different effects depending on the crop. This suggests that crop-specific response to changes in irrigation costs needs to be consider when designing policies that address water use efficiency in agriculture, such as water pricing. Responsiveness of vegetable and fruit production to variations in irrigation costs is limited, resulting in unchanged or even increased water use when these costs rise. This entails that high water prices are required to induce a decline in water use, with a negative impact on 
agricultural income (Esteve et al., 2015; Expósito and Berbel, 2017; Gutierrez-Martin and Gómez-Gómez, 2011; Perez-Blanco et al., 2015). In addition, increased irrigation costs linked to the energy dependence in agriculture need to be considered when addressing the sustainability of the sector. Harmonised agricultural and energy policies are needed to account for the increasing interconnections between agriculture and energy sectors. According to stakeholders, more flexible energy regulations are required to alleviate the cost burden of energy. Meantime, efforts from agricultural policies are also required to support measures that enhance energy efficiency use in agriculture (Fernández García et al., 2016; Rocamora et al., 2012; Rodríguez Díaz et al., 2009; Tarjuelo et al., 2015).

Furthermore, the observed expansion on permanent crops in the region in detriment of annual crops has also political implications. In comparison with annual crops, citrus and other fruits productions are generally more water demanding and more sensitive to extreme events, which are expected to be more frequent under climate change conditions (Roudier et al., 2016). This points to the need for adaptation strategies that enhance resilience of agricultural systems to climate change impacts by improving agricultural water management (Perry et al., 2009; Ward and Pulido-Velázquez, 2008), water governance (i.e. water rights, water markets) (Gomez et al., 2017, Ward and Pulido-Velazquez, 2008) and water use efficiency (Elliot et al., 2014; Fader et al. 2016). In this regard, our results show that irrigation efficiency gains can contribute to lower water use and reduce crop responsiveness to irrigation costs. As illustrated by Berbel et al., (2018b), that conducted a microeconomic analysis to investigate the effects of irrigation efficiency on water use and water consumption, water demand functions are more inelastic as irrigation efficiency improves.

Nevertheless, measures are required to reduce the rebound effect observed in the last decades, which led to the increase in water use as a consequence of improved water use efficiency (López-Gunn et al., 2012, Berbel et al., 2015). A number of studies attempted to assess the impact of irrigation water use improvement on water saving over the last years, highlighting that the expansion of irrigated land and changes in crop patterns are major factors behind this effect (Berbel et al., 2015; Perry et al., 2017). Our results show that irrigation efficiency enhancement generally reduces water use, yet this factor is not driven irrigated land increases (Berbel et al., 2018b). Meanwhile, an increase in irrigated land devoted to permanent crops is observed, in line with empirical studies (Fernández García et al., 2014; García-Vila et al. 2008) and prospects from stakeholders. Therefore, political instruments are needed to govern irrigated land and allotment of water saved (Alarcón et al., 2016; Grafton et al., 2018). 
Using CAPRI-Water enables building the analysis on a baseline calibrated to official projections (i.e. EU Agricultural outlook) and accounting for climate-induced impacts on crop productivity over the horizon 2050 as provided by well-established crop models. Another advantage of this approach, highlighted as a limitation in other studies (Berbel et al., 2019), is that the analysis of scenarios permits to differentiate factors that govern irrigated land expansion from projected trends. Additionally, CAPRI-Water accounts from market feedback, which has an important role to play in the agricultural sector under climate change (Blanco et al., 2017), thought this is beyond the scope of this analysis as we focus on one single region to conduct the sensitivity analysis. Nonetheless, the global nature and EU regional focus of the model lead to some limitations regarding the introduction of the water dimension mainly due to data constraints. CAPRI-Water draws on EU-wide harmonised data sources to model agricultural water use at the regional level within Europe. Regional water databases are often incomplete for some variables that are basin-specific and are not generally reported in EU-wide statistics. Whereas the model computes water use, water return flows are not explicitly consider, as done by other economic studies performed a basin-scale, irrigated are or field level where data can be more easily available (Berbel et al. 2018b; Blanco et al., 2014; Ward and PulidoVelazquez, 2008). This limits the assessment of the potential redistribution of water within a basin resulting from variations in water use (Ward and Pulido Velázquez 2008). 


\section{Conclusions}

\subsection{Major findings and research contributions}

This research builds on a novel methodological approach that integrates modelling techniques, participatory approaches and sensitivity analysis to improve knowledge on the interrelations between agriculture and the environment to support evidence-based decisionmaking. The strength of this methodology relies on the application of a multi-scale and crosssectoral approach that combines well-established tools and engages stakeholders in the process.

The application of the agro-economic model CAPRI has enabled the assessment of global and regional impacts of climate-induced changes in crop productivity on agricultural markets under different climate scenarios, which draws on three climate models, the RCPs 4.5 and 8.5, and the consideration of carbon fertilisation effects.

There is a clear evidence that assessments of climate change impacts on agriculture need to consider not only biophysical effects on crop yields but also economic impacts in order to take into account market-driven adaptation strategies. Furthermore, considering different climate change scenarios enables us to account for the range of uncertainty linked to the effects of climate change. Results show that the carbon fertilisation effect is a key factor in the impact of climate change on agriculture. Therefore, despite the controversial results of previous experimental studies, this research suggests that the carbon fertilisation effect should be taken into account in bio-economic assessments to evaluate the whole range of variability of climate effects on agriculture.

Uneven impacts of climate change on production across the world gives international trade an important role in counterbalancing effects and ensuring food security. This suggests that decision-makers must engage to guarantee the coherence between trade regulations and climate policies. Meanwhile, region-specific strategies tailored to local challenges are required to tackling global climate change impacts.

Through the application of the FCM methodology, we have involved decision-makers in the identification of the main nexus interlinkages, while promoting discussion and consensus building among stakeholders from different sectors. Furthermore, the exploitation of FCM model dynamics has enabled the analysis of different scenarios to improve our knowledge on the system behaviour. 
Stakeholders agree that climate change and water availability are the main drivers in the WEF nexus in Andalusia. Other variables with significant roles in building interlinkages in the nexus are energy cost, food production, irrigated agriculture, socio-economic factors, irrigation water use, environmental conservation, and farm performance indicators. The scenario analysis demonstrates the interdependencies among nexus sectors and the existence of unanticipated effects when changing variables in the system. Although results from scenarios only show relative variable changes, they allow improved analysis of the stakeholders' perceptions of the WEF nexus and contribute to improving understanding of the system's dynamics. The participatory approach performed in this research enables the development of a conceptual model of the WEF nexus in Andalusia that is suitable for the stakeholders that will support the nexus assessment.

Better informed decision-making requires consideration of the diverse stakeholders' perspectives to develop consistent and coordinated policies. In addition, there is a need for assessments that enhance the development of evidence-based policies, which suggest that improved cooperation between policy makers and the scientific community is crucial. This can only be done by considering stakeholders' concerns and needs, and increasing reliability and transparency on research results.

The sensitivity analysis of the CAPRI-Water results based on drivers selected in collaboration with stakeholders has allowed us to disentangle the key driving forces of agricultural development, in particular the sensitivity of irrigated land, irrigation water use and agricultural income. The use of the sensitivity analysis offers valuable insights into the contribution of different scenario drivers to model results that might support decision-making in agriculture under a climate change context.

The results from the analysis indicate that the cost of water is the most determining factor in shaping agricultural land, with the magnitude of the sensitivity to this driver differing across crops. Furthermore, the most influential factors with respect to irrigation water use are irrigation costs and irrigation efficiency, which counteract each other. The relevance of these drivers largely depends on the crop: while citrus fruits water use is driven by irrigation costs and irrigation efficiency, cereal water use is mostly determined by irrigation costs. In contrast, variations in water availability for agriculture do not seem to have a significant effect on irrigated land and irrigation water use. This is consistent with results from other studies where irrigation costs emerge as a limiting factor in irrigation despite the availability of water for agriculture. 
Identifying the main drivers of future agricultural development provides meaningful information for developing policies that effectively enhance sustainable agriculture and water management in Andalusia. Tariff-based policies to promote resource use efficiency, such as water pricing in irrigation, must consider crop sensitivity to irrigation costs shifts and its implications for income. Furthermore, a greater consistency between agricultural and energy policies is required to reduce the cost burden on energy and promote energy use efficiency in irrigated agriculture. Additionally, policies aimed at improving water use efficiency can contribute to strengthen the resilience and adaptation capacity of future agricultural systems to climate change, though instruments are required to deal with the rebound effect.

With regard to the methodological approach, the application of the global agro-economic model CAPRI allowed for exploring climate change impacts both at global and regional levels, considering market feedback. The exploitation of FCM enabled systems modelling with limited data, including both quantitative and qualitative variables, whilst considering feedback relationships between concepts. Furthermore, this methodology encourages stakeholder discussion, facilitates their involvement in the modelling process and increases reliance on the model. The application of sensitivity analysis with finite changes decomposition enables one to compute individual and interaction effects of selected drivers using a computationally feasible number of model runs, which is essential for a large modelling system such as CAPRI. Although this technique is considered as a local sensitivity analysis tool, it is well suited to understand model behaviour and results variation in response to the shifts in model parameters. However, when the aim of the analysis is to assess the whole range of results uncertainty, global sensitivity analysis is highly recommended. Additionally, this exercise can support model diagnostics and help to define parameters for which projections are either not readily available or are surrounded by high uncertainty.

\subsection{Limitations and further research}

The underlying assumptions of the bio-economic modelling approach lead to several limitations in this research with regards to the assessment of climate change impacts on agriculture. First, biophysical models omit many restricting factors such as extreme weather events or changes in diseases prevalence. Second, the economic model includes several assumptions with regard to macroeconomic environment and behavioural parameters over the long run (e.g., price elasticities) as well as simplifying diversity across farms and regions. Third, adaptation strategies to climate change, as for example the implementation of 
adaptation policies, were not taken into account. Further research would be required to explore the impacts of climate and trade policies.

The outcome from the FCM model needs to be interpreted in relative terms (no absolute changes in variables can be provided). Another important drawback is the absence of temporal dimension in the model. This suggests that FCM might be combined with quantitative tools to provide robust policy assessments. Therefore, outcomes from FCM are being used in the development of an SDM to quantitatively assess the impact of nexuscompliant policies in Andalusia in the medium and long term.

The sensitivity analysis conducted offers valuable information about future agricultural development under different assumptions. Nevertheless, in comparison to the global sensitivity analysis, the approach applied in this study is more restricted with regards to the number of factors and the range of uncertainty considered. Focusing on only three drivers, even if they have been clearly identified by the stakeholders, inevitably reduces the scope of the analysis and narrows the range of uncertainty considered. Further research is needed to explore driver's effects under different assumptions. The use of the worst-case and best-case scenarios has proven effective to assess the impacts of changes in the selected drivers. Notwithstanding, the approach applied would benefit from the analysis of other drivers that have shown to have an impact in water use in agriculture, such as CAP payments, or policy measures, such as subsidies for using non-conventional water resources. 


\section{References}

Adams, R. M., Hurd, B. H., Lenhart, S., \& Leary, N. (1998). Effects of global climate change on agriculture: an interpretative review. Climate research, 11(1), 19-30, doi: 10.3354/cr011019.

Ainsworth, E. A., \& Long, S. P. (2005). What have we learned from 15 years of free-air CO2 enrichment (FACE)? A meta-analytic review of the responses of photosynthesis, canopy properties and plant production to rising CO2. New phytologist, 165(2), 351-372, doi: 10.1111/j.1469-8137.2004.01224.x.

Alarcón, J., Garrido, A., \& Juana, L. (2016). Modernization of irrigation systems in Spain: review and analysis for decision making. International Journal of Water Resources Development, 32(3), 442-458, doi: 10.1080/07900627.2015.1123142.

Albrecht, T. R., Crootof, A., \& Scott, C. A. (2018). The Water-Energy-Food Nexus: A systematic review of methods for nexus assessment. Environmental Research Letters, 13(4), 043002, doi: 10.1088/1748-9326/aaa9c6.

Alexandratos, N. \& Bruinsma J. (2012). World agriculture towards 2030/2050: the 2012 revision. ESA Working paper No. 12-03, FAO: Rome (Italy).

Allouche, J., Middleton, C., \& Gyawali, D. (2019). The Water-Food-Energy Nexus: Power, Politics, and Justice. Routledge.

Argent, R. M., Sojda, R. S., Giupponi, C., Mclntosh, B., Voinov, A. A., \& Maier, H. R. (2016). Best practices for conceptual modelling in environmental planning and management. Environmental modelling \& software, 80, 113-121, doi: 10.1016/j.envsoft.2016.02.023.

Axelrod, R. (1976). Structure of Decision: The Cognitive Maps of Political Elites. Princeton University Press, Princeton, NJ.

Baldos, U. L. C., \& Hertel, T. W. (2015). The role of international trade in managing food security risks from climate change. Food Security, 7(2), 275-290, doi: 10.1007/s12571-0150435-z.

Barton, D. N., Kuikka, S., Varis, O., Uusitalo, L., Henriksen, H. J., Borsuk, M., ... \& Linnell, J. D. (2012). Bayesian networks in environmental and resource management. Integrated environmental assessment and management, 8(3), 418-429, doi: 10.1002/ieam.1327. 
Basco-Carrera, L., Warren, A., van Beek, E., Jonoski, A., \& Giardino, A. (2017). Collaborative modelling or participatory modelling? A framework for water resources management. Environmental Modelling \& Software, 91, 95-110, doi: 10.1016/j.envsoft.2017.01.014.

Berbel, J., Expósito, A., Gutiérrez-Martín, C., \& Mateos, L. (2019). Effects of the Irrigation Modernization in Spain 2002-2015. Water Resources Management, 1-15, doi: 10.1007/s11269-019-02215-w.

Berbel, J., Gutiérrez-Martín, C., \& Expósito, A. (2018a). Impacts of irrigation efficiency improvement on water use, water consumption and response to water price at field level. Agricultural water management, 203, 423-429, doi: 10.1016/j.agwat.2018.02.026.

Berbel, J., Schellekens, J., Expósito, A., Borrego, M., \& Montilla-Lopez, N. (2018b). Review of alternative water allocation options. Deliverable to Task A4B of the BLUE2 project. Study on EU integrated policy assessment for the freshwater and marine environment, on the economic benefits of EU water policy and on the costs of its non-implementation. Report to Directorate General for the Environment of the European Commission.

Berbel, J., Gutiérrez-Martín, C., Rodríguez-Díaz, J. A., Camacho, E., \& Montesinos, P. (2015). Literature review on rebound effect of water saving measures and analysis of a Spanish case study. Water Resources Management, 29(3), 663-678, doi: 10.1007/s11269-0140839-0.

Berbel, J., Pedraza V., \& Giannoccaro G. (2013). The trajectory towards basin closure of a European river: Guadalquivir. International Journal of River Basin Management, 11(1), 111119, doi: 10.1080/15715124.2013.768625.

Bhaduri, A., Ringler, C., Dombrowski, I., Mohtar, R., \& Scheumann, W. (2015). Sustainability in the water-energy-food nexus. Water International 40:5-6, 723-732, doi: $10.1080 / 02508060.2015 .1096110$

Bijl, D. L., Biemans H., Bogaart P. W., Dekker S. C., Doelman J. C., Stehfest E., van Vuuren, D. P. (2018). A global analysis of future water deficit based on different allocation mechanisms. Water Resources Research, 54(8), 5803-5824, doi: doi.org/10.1029/2017WR021688.

Bisselink, B., Bernhard, J., Gelati E., Adamovic, M., Guenther, S., Mentaschi, L. De Roo, A. (2018). Impact of a changing climate, land use, and water usage on Europe's water resources, EUR 29130 EN, Publications Office of the European Union, Luxembourg, ISBN 978-92-79-80287-4, doi:10.2760/847068. 
Blanco, M., Witzke, P., Barreiro, Hurle J., Martinez, P., Salputra, G., Hristov, J. (2018). CAPRI Water 2.0: an upgraded and updated CAPRI water module, EUR 29498 EN, Luxembourg: Publications Office of the European Union, 2015, doi: 10.2760/83691.

Blanco, M., Ramos, F., Van Doorslaer, B., Martínez, P., Fumagalli, D., Ceglar, A., \& Fernández, F. J. (2017). Climate change impacts on EU agriculture: A regionalized perspective taking into account market-driven adjustments. Agricultural systems, 156, 52-66, doi: 10.1016/j.agsy.2017.05.013.

Blanco, M., Witzke, P., Pérez Domínguez, I., Salputra, G., Martínez, P. (2015). Extension of the CAPRI model with an irrigation sub-module; EUR 27737 EN; Luxembourg: Publications Office of the European Union, 2015, doi: 10.2791/319578.

Blanco, M., \& Viladrich-Grau, M. (2014). La creación de un centro de intercambio de derechos de agua en la Cuenca del Segre y la contribución de los flujos de retorno. Información técnica económica agraria, 374-399.

Bondeau, A., Smith, P. C., Zaehle, S., Schaphoff, S., Lucht, W., Cramer, W., Gerten, D., LotzeCampen, H., Müller, C., Reichstein, M., \& Smith, B. (2007). Modelling the role of agriculture for the 20th century global terrestrial carbon balance. Global Change Biology, 13(3), 679706, doi: 10.1111/j.1365-2486.2006.01305.x

Boogaard, H.L., De Wit, A.J.W., te Roller, J.A., Van Diepen, C.A. (2014). User's guide for the WOFOST control centre 2.1 and the crop growth simulation model WOFOST 7.1.7. Wageningen University \& Research Centre.

Borgonovo, E., \& Plischke, E. (2016). Sensitivity analysis: a review of recent advances. European Journal of Operational Research, 248(3), 869-887, doi: 10.1016/j.ejor.2015.06.032.

Borgonovo, E., \& Peccati, L. (2011). Managerial insights from service industry models: a new scenario decomposition method. Annals of Operations Research, 185(1), 161-179, doi: 10.1007/s10479-009-0617-1.

Borgonovo, E., \& Smith, C. L. (2011). A study of interactions in the risk assessment of complex engineering systems: An application to space PSA. Operations Research, 59(6), 1461-1476, doi: 10.1287/opre.1110.0973.

Borgonovo, E. (2010). Sensitivity analysis with finite changes: An application to modified EOQ models. European Journal of Operational Research, 200(1), 127-138, doi:10.1016/j.ejor.2008.12.025. 
Bosma, C., Glenk, K., \& Novo, P. (2017). How do individuals and groups perceive wetland functioning? Fuzzy cognitive mapping of wetland perceptions in Uganda. Land Use Policy, 60, 181-196, doi: 10.1016/j.landusepol.2016.10.010.

Bousquet, F., Barreteau, O., Le Page, C., Mullon, C., \& Weber, J. (1999). An environmental modelling approach: the use of multi-agent simulations. Advances in Environmental and Ecological Modelling, 113, 122.

Britz, W., \& Witzke, H.P. (2014). CAPRI Model Documentation 2014. University of Bonn. Available at: http://www.capri-model.org/docs/capri_documentation.pdf.

Brooks, J. \& Matthews, A. (2015). Trade Dimensions of Food Security. OECD Food, Agriculture and Fisheries Papers, No. 77, OECD Publishing: Paris (France), doi: 10.1787/5js65xn790nven.

Brouwer, C., Prins K., \& Heibloem, M. (1989). Irrigation water management: irrigation scheduling. Training manual, 4.

Burek, P., Satoh, Y., Fischer, G., Kahil, M. T., Scherzer, A., Tramberend, S., Nava, L. F., Wada, Y., Eisner, S., Flörke, M., Hanasaki, N., Magnuszewski, P., Cosgrove, \& B., Wilberg, D. (2016). Water futures and solution-fast track initiative.

Byers, E., Gidden, M., Leclère, D., Balkovic, J., Burek, P., Ebi, K., Greve, P., Grey, D., Havlik, P., \& Hillers, A. (2018). Global exposure and vulnerability to multi-sector development and climate change hotspots. Environmental Research Letters, 13(5), 055012, doi: 10.1088/1748-9326/aabf45.

Calatrava, J., García-Valiñas, M., Garrido, A., and González-Gómez, F. (2015). Water pricing in Spain: Following the footsteps of somber climate change projections. In Water pricing experiences and innovations (pp. 313-340). Springer, Cham.

Calzadilla, A., Rehdanz, K., Betts, R., Falloon, P., Wiltshire, A., \& Tol, R. S. (2013). Climate change impacts on global agriculture. Climatic change, 120(1-2), 357-374, doi: 10.1007/s10584-013-0822-4

CEDEX (2017). Evaluación del impacto del cambio climático en los recursos hídricos y sequías en España. Centro de Estudios y Experimentación en Obras Públicas. Ministerio de Fomento, Gobierno de España: Madrid, España, 2017.

Christen, B., Kjeldsen, C., Dalgaard, T., \& Martin-Ortega, J. (2015). Can fuzzy cognitive mapping help in agricultural policy design and communication?. Land Use Policy, 45, 64-75. 
Ciscar, J.C., Ibarreta D., Soria A., Dosio A., Toreti A., Ceglar A., Fumagalli D., Dentener F., Lecerf R., Zucchini A., Panarello L., Niemeyer S., Pérez-Domínguez I., Fellmann T., Kitous, A., Després, J., Christodoulou, A., Demirel, H., Alfieri, L., Dottori, F., Vousdoukas, M.I., Mentaschi, L., Voukouvalas, E., Cammalleri, C. , Barbosa, P., Micale, F., Vogt, J.V., Barredo, J.I. , Caudullo, G., Mauri, A., de Rigo, D., Libertà, G., Houston Durrant, T., Artés Vivancos, T., San-Miguel-Ayanz, J., Gosling, S.N., Zaherpour, J., De Roo, A., Bisselink, B., Bernhard, J., Bianchi, L., Rozsai, M., Szewczyk, W., Mongelli I. \& Feyen, L. (2018). Climate impacts in Europe: Final report of the JRC PESETA III project, EUR 29427 EN, Publications Office of the European Union, Luxembourg, ISBN 978-92-79-97218-8, doi: 10.2760/93257.

Corominas, J., \& Cuevas, R. (2017). Análisis crítico de la modernización de regadíos. Pensando el futuro: ¿cómo será el nuevo paradigma? In Efectos de la Modernización de Regadío en España; Berbel, J., Gutiérrez-Martin, C., Eds.; Cajamar Caja Rural: Almería, Spain, 2017; pp. 273-308.

Corominas, J. (2011). Análisis de las Modernizaciones de Regadíos en Andalucía. Consejería de Agricultura y Pesca, Junta de Andalucía: Sevilla, Spain.

Corominas, J. (2010). Agua y energía en el riego, en la época de la sostenibilidad. Ingeniería del agua, 17(3), 219-233.

De Marchi, B., \& Ravetz, J. R. (2001). Participatory approaches to environmental policy. EVEConcerted Action, Policy Research Brief Number 10, Cambridge Research for the Environment: Cambridge.

De Roo, A., Bouraoui F., Burek P., Bisselink B., Ine Vandecasteele I., Mubareka S., Salamon P., Pastori M., Zambrano M., Thiemig V., Bianchi A., \& Lavalle C. (2012). Current water resources in Europe and Africa - Matching water supply and water demand. Luxembourg: Publications Office of the European Union, 2012, doi: 10.2788/16165.

De Stefano, L. \& Llamas, M.R. (Eds.) (2012). Water, Agriculture and the Environment in Spain: Can We Square the Circle? CRC Press: Delft, The Netherlands, ISBN 978-0-415-63152-5.

De Strasser, L., Lipponen, A., Howell,s M., Stec, S., \& Bréthaut, C. (2016). A methodology to assess the water energy food ecosystems nexus in transboundary river basins. Water 8(2), 59, doi: 10.3390/w8020059.

Delincé, J., Ciaian, P., \& Witzke, H. P. (2015). Economic impacts of climate change on agriculture: the AgMIP approach. Journal of Applied Remote Sensing, 9(1), 097099, doi: 10.1117/1.JRS.9.097099. 
Deryng, D., Conway, D., Ramankutty, N., Price, J., \& Warren, R. (2014). Global crop yield response to extreme heat stress under multiple climate change futures. Environmental Research Letters, 9(3), 034011, doi: 10.1088/1748-9326/9/3/034011.

Doelman, J. C., Stehfest, E., Tabeau, A., van Meijl, H., Lassaletta, L., Gernaat, D. E., Hermans, K., Harmsen, M., Daioglou, V., Biemans, H., van der Sluis, S., \& van Vuuren D.P.. (2018). Exploring SSP land-use dynamics using the IMAGE model: Regional and gridded scenarios of land-use change and land-based climate change mitigation. Global Environmental Change, 48, 119-135, doi: 10.1016/j.gloenvcha.2017.11.014.

Donnelly, C., Greuell, W., Andersson, J., Gerten, D., Pisacane, G., Roudier, P., \& Ludwig, F. (2017). Impacts of climate change on European hydrology at 1.5, 2 and 3 degrees mean global warming above preindustrial level. Climatic Change 143: 13, doi.org/10.1007/s10584-017-1971-7, doi: 10.1007/s10584-017-1971-7.

Ebi, K. L., Hallegatte, S., Kram, T., Arnell, N. W., Carter, T. R., Edmonds, J., Kriegler, E., Mathur, R., O'Neill, B.C., Riahi, K., Winkler, H., Van Vuuren, D. P. \& Zwickel, T. (2014). A new scenario framework for climate change research: background, process, and future directions. Climatic Change 122: 363-372, doi: 10.1007/s10584-013-0912-3.

EC (2019a). Implementation of the Circular Economy Action Plan. European Commission, Brussels, SWD (2019) 90 final.

EC (2019b). Report from the Commission to the European Parliament and the Council on the implementation of the Water Framework Directive (2000/60/EC) and the Floods Directive (2007/60/EC), Second River Basin Management Plans, First Flood Risk Management Plans. European Commission, Brussels, SWD (2019) 42 final.

EC (2018a). A sustainable Bioeconomy for Europe: Strengthening the connection between economy, society and the environment. European Commission, Brussels, SWD (2018) 431 final.

EC (2018b). A Clean Planet for all. A European strategic long-term vision for a prosperous, modern, competitive and climate neutral economy. European Commission, Brussels, COM (2018) 773 final.

EC (2018c). EU Agricultural outlook for the agricultural markets and income 2017-2030.

EC (2015). Better Regulation Guidelines. European Commission, Strasbourg, SWD (2015) 111 final. 
EC (2014). A policy framework for climate and energy in the period from 2020 to 2030. European Commission, Brussels, COM (2014) 15 final.

EC (2012a). A Blueprint to Safeguard Europe's Water Resources. European Commission, Brussels, COM (2012) 673 final.

EC (2012b). Report from the Commission to the European Parliament and the Council on the Implementation of the Water Framework Directive (2000/60/EC) - River Basin Management Plans. European Commission, Brussels, COM (2012) 670 final.

ECA (2014). Integration of EU water policy objectives with the CAP: a partial success. European Court of Auditors, Luxembourg, doi: 10.2865/15216.

EEA (2018). Water use in Europe Quantity and quality face big challenges. European Environmental Agency: Copenhagen, Denmark, 2018.

EEA (2012). European waters - assessment of status and pressures. European Environmental Agency: Copenhagen, Denmark, 2018.

Elbehri, A. (2015). Climate change and food systems: global assessments and implications for food security and trade. FAO: Rome, Italy.

Elliott, J., Deryng, D., Müller, C., Frieler, K., Konzmann, M., Gerten, D., ... \& Eisner, S. (2014). Constraints and potentials of future irrigation water availability on agricultural production under climate change. Proceedings of the National Academy of Sciences, 111(9), 32393244, doi: 10.1073/pnas.1222474110.

Endo, A., Tsurita, I., Burnett, K., \& Orencio, P. M. (2017). A review of the current state of research on the water, energy, and food nexus. Journal of Hydrology: Regional Studies, 11, 20-30, doi: 10.1016/j.ejrh.2015.11.010.

Esteve, P., Varela-Ortega, C., Blanco-Gutiérrez, I., \& Downing, T. E. (2015). A hydro-economic model for the assessment of climate change impacts and adaptation in irrigated agriculture. Ecological Economics, 120, 49-58, doi: 10.1016/j.ecolecon.2015.09.017.

Expósito, A., \& Berbel, J. (2017). Why is water pricing ineffective for deficit irrigation schemes? A case study in southern Spain. Water resources management, 31(3), 1047-1059, doi: 10.1007/s11269-016-1563-8.

Eschenbach, T.G. (1992). Spiderplots versus Tornado Diagrams for Sensitivity Analysis. Interfaces 22(6):40-46, doi: 10.1287/inte.22.6.40. 
Fader, M., Shi, S., Bloh, W. V., Bondeau, A., \& Cramer, W. (2016). Mediterranean irrigation under climate change: more efficient irrigation needed to compensate for increases in irrigation water requirements. Hydrology and Earth System Sciences, 20(2), 953-973, doi: 10.5194/hess-20-953-2016.

FAO (2017). The future of food and agriculture - Trends and challenges. Food and Agriculture Organization of the United Nations, Rome.

FAO (2014). The Water-Energy-Food Nexus: A new approach in support of food security and sustainable agriculture. Food and Agriculture Organization of the United Nations, Rome.

FAO (2011). The state of the world's land and water resources for food and agriculture Managing systems at risk. Food and Agriculture Organization of the United Nations, Rome.

Fernández, F. J., \& Blanco, M. (2015). Modelling the economic impacts of climate change on global and European agriculture: Review of economic structural approaches. Economics: The Open-Access, Open-Assessment E-Journal, 9(2015-10), 1-53, 10.5018/economicsejournal.ja.2015-10.

Fernández García, I., Montesinos, P., Poyato, E. C., \& Díaz, J. R. (2016). Energy cost optimization in pressurized irrigation networks. Irrigation science, 34(1), 1-13, doi: 10.1007/s00271-015-0475-3.

Fernandez García, I., Díaz, J. R., Poyato, E. C., Montesinos, P., \& Berbel, J. (2014). Effects of modernization and medium term perspectives on water and energy use in irrigation districts. Agricultural systems, 131, 56-63, doi: 10.1016/j.agsy.2014.08.002.

Fischer, G., Tubiello, F. N., Van Velthuizen, H., \& Wiberg, D. A. (2007). Climate change impacts on irrigation water requirements: Effects of mitigation, 1990-2080. Technological Forecasting and Social Change, 74(7), 1083-1107, doi: 10.1016/j.techfore.2006.05.021.

Frank, S., Witzke, H. P., Zimmermann, A., Havlík, P., \& Ciaian, P. (2014). Climate change impacts on European agriculture: A multi model perspective. 14th Congress of the European Association of Agricultural Economics, Ljubljana (Slovenia), August 26-29.

Gabbert S., Van Ittersum M., Kroeze C., Stalpers S., Ewert F., \& Olsson J. A. (2010). Uncertainty analysis in integrated assessment: the users' perspective. Regional Environmental Change, 10(2), 131-143, doi: 10.1007/s10113-009-0100-1.

García-Vila M., Lorite I. J., Soriano M. A., \& Fereres E. (2008). Management trends and responses to water scarcity in an irrigation scheme of Southern Spain. Agricultural Water Management, 95(4), 458-468, doi: doi.org/10.1016/j.agwat.2007.11.009. 
Garrote L., Iglesias A., Granados A., Mediero L., \& Martin-Carrasco F. (2015). Quantitative assessment of climate change vulnerability of irrigation demands in Mediterranean Europe. Water Resources Management, 29(2), 325-338, doi: 10.1007/s11269-014-0736-6.

Gifford, R. M. (2004). The CO2 fertilising effect-does it occur in the real world?. New Phytologist, 163(2), 221-225, doi: 10.1111/j.1469-8137.2004.01133.x.

Gómez Gómez, C. M., Pérez-Blanco, C. D., Adamson, D., \& Loch, A. (2018). Managing water scarcity at a river basin scale with economic instruments. Water Economics and Policy, 4(01), 1750004, doi: 10.1142/S2382624X17500047.

González Perea, R., García, I. F., Arroyo, M. M., Díaz, J. R., Poyato, E. C., \& Montesinos, P. (2017). Multiplatform application for precision irrigation scheduling in strawberries. Agricultural Water Management, 183, 194-201, doi: 10.1016/j.agwat.2016.07.017.

Gornall, J., Betts, R., Burke, E., Clark, R., Camp, J., Willett, K., \& Wiltshire, A. (2010). Implications of climate change for agricultural productivity in the early twenty-first century. Philosophical Transactions of the Royal Society B: Biological Sciences, 365(1554), 29732989, doi.org/10.1098/rstb.2010.0158.

Grafton, R. Q., Williams, J., Perry, C. J., Molle, F., Ringler, C., Steduto, P., ... \& Allen, R. G. (2018). The paradox of irrigation efficiency. Science, 361(6404), 748-750, doi: 10.1126/science.aat9314.

Gray, S., Voinov, A., Paolisso, M., Jordan, R., BenDor, T., Bommel, P., Glynn, P., Hedelin, B., Hubacek, K., Introne, J., Kolagani, N., Laursen, B., Prell, C., Schmitt, L., Singer, A., Sterling, E., \& Zellner, M. (2018). Purpose, processes, partnerships, and products: four Ps to advance participatory socio-environmental modeling. Ecological Applications, 28(1), 46-61, doi: 10.1002/eap.1627.

Gray, S. A., Gray, S., De Kok, J. L., Helfgott, A. E., O'Dwyer, B., Jordan, R., \& Nyaki, A. (2015). Using fuzzy cognitive mapping as a participatory approach to analyze change, preferred states, and perceived resilience of social-ecological systems. Ecology and Society, 20(2), doi: 10.5751/ES-07396-200211.

Gray, S. A., Zanre, E., \& Gray, S. R. J. (2014). Fuzzy cognitive maps as representations of mental models and group beliefs. In Fuzzy cognitive maps for applied sciences and engineering. Springer, Berlin, Heidelberg, p.29-48, doi: 10.1007/978-3-642-39739-4_2. 
Gray, S., Chan, A., Clark, D., \& Jordan, R. (2012). Modeling the integration of stakeholder knowledge in social-ecological decision-making: benefits and limitations to knowledge diversity. Ecological Modelling, 229, 88-96, doi: 10.1016/j.ecolmodel.2011.09.011.

Gutierrez-Martin, C., \& Gomez, C. G. (2011). Assessing irrigation efficiency improvements by using a preference revelation model. Spanish Journal of Agricultural Research, 9(4), 10091020, doi: 10.5424/sjar/20110904-514-10.

Halbe, J., Pahl-Wostl, C., \& Adamowski, J. (2018). A methodological framework to support the initiation, design and institutionalization of participatory modeling processes in water resources management. Journal of Hydrology, 556, 701-716, doi: 10.1016/j.jhydrol.2017.09.024.

Hanasaki, N., Fujimori, S., Yamamoto, T., Yoshikawa, S., Masaki, Y., Hijioka, Y., Kainuma, M., Kanamori, Y., Masui, T., Takahashi, K., \& Kanae S. (2013). A global water scarcity assessment under Shared Socio-economic Pathways-Part 1: Water use. Hydrology and Earth System Sciences, 17(7), 2375-2391, doi: 10.5194/hess-17-2375-2013.

Harary, F., Norman, R.Z., Cartwright, D. (1965). Structural Models: An Introduction to the Theory of Directed Graphs; John Wiley \& Sons: New York, NY, USA.

Hardy, L., Garrido, A., \& Juana, L. (2012). Evaluation of Spain's water-energy nexus. International Journal of Water Resources Development 28(1), 151-170, doi: 10.1080/07900627.2012.642240.

Hobbs, B. F., Ludsin, S. A., Knight, R. L., Ryan, P. A., Biberhofer, J., \& Ciborowski, J. J. (2002). Fuzzy cognitive mapping as a tool to define management objectives for complex ecosystems. Ecological Applications, 12(5), 1548-1565, doi: 10.1890/10510761(2002)012[1548:FCMAAT]2.0.CO;2.

Hoff, H. (2011). Understanding the Nexus. Background Paper for the Bonn 2011 Conference: The Water, Energy and Food Security Nexus. Stockholm Environment Institute Stockholm. Available at: https://www.sei-international.org/publications?pid=1977.

Höllermann, B., \& Evers, M. (2017). Perception and handling of uncertainties in water management-A study of practitioners' and scientists' perspectives on uncertainty in their daily decision-making. Environmental Science \& Policy, 71, 9-18, doi: 10.1016/j.envsci.2017.02.003.

Intrigliolo, D.S., \& Alarcón, J. (2017). El riego de precisión. El nuevo desafío de los regadíos modernizados. In Efectos de la Modernización de Regadío en España; Berbel, J., Gutiérrez- 
Martin, C., Eds.; Cajamar Caja Rural: Almería, Spain, 2017; pp. 273-308, ISBN 978-8495531-83-4. (In Spanish).

IPCC (2013). Climate Change 2013: The Physical Science Basis. Contribution of Working Group I to the Fifth Assessment Report of the Intergovernmental Panel on Climate Change [Stocker, T.F., D. Qin, G.K. Plattner, M. Tignor, S.K. Allen, J. Boschung, A. Nauels, Y. Xia, V. Bex and P.M. Midgley (eds.)]. Cambridge University Press, Cambridge, United Kingdom and New York, NY, USA, 1535 pp.

Junta de Andalucía (2018a). Informe económico de Andalucía 2017. Consejería de Economía, Hacienda y Administración Pública, Junta de Andalucía: Seville, Spain.

Junta de Andalucía (2018b). Estrategía Andaluza de Bioeconomía Circular. Junta de Andalucía: Seville, Spain.

Junta de Andalucía (2018c). Informe de medio ambiente de Andalucía 2017. Consejería de Medio Ambiente y Ordenación del Territorio, Junta de Andalucía: Seville, Spain.

Junta de Andalucía (2011). Agenda del regadío andaluz H-2015. Consejería de Agricultura, Pesca y Alimentación, Junta de Andalucía: Seville, Spain.

Kafetzis, A., McRoberts, N., \& Mouratiadou, I. (2010). Using fuzzy cognitive maps to support the analysis of stakeholders' views of water resource use and water quality policy. In Fuzzy cognitive maps (pp. 383-402). Springer, Berlin, Heidelberg, doi: 10.1007/978-3-642-032202_16.

Konti, A., \& Damigos, D. (2018). Exploring strengths and weaknesses of bioethanol production from bio-waste in Greece using Fuzzy Cognitive Maps. Energy Policy, 112, 4-11, 10.1016/j.enpol.2017.09.053.

Konzmann, M., Gerten, D., \& Heinke, J. (2013). Climate impacts on global irrigation requirements under $19 \mathrm{GCMs}$, simulated with a vegetation and hydrology model. Hydrological Sciences Journal, 58(1), 88-105, doi : 10.1080/02626667.2013.746495.

Kosko, K. (1994). Fuzzy Systems as Universal Approximators. ISEE Transactions on Computers 43, 1329-1333.

Kosko, K. (1986). Fuzzy cognitive maps. International Journal of Man-Machine Studies, 24(1), 65-75, doi: 10.1016/S0020-7373(86)80040-2. 
Kok, K. (2009). The potential of Fuzzy Cognitive Maps for semi-quantitative scenario development, with an example from Brazil. Global Environmental Change 19, 122-133, doi: 10.1016/j.gloenvcha.2008.08.003.

Kriegler, E., O'Neill, B. C., Hallegatte, S., Kram, T., Lempert, R. J., Moss, R. H., \& Wilbanks, T. (2012). The need for and use of socio-economic scenarios for climate change analysis: a new approach based on shared socio-economic pathways. Global Environmental Change, 22(4), 807-822, doi: 10.1016/j.gloenvcha.2012.05.005.

Leip A., Weiss F., Wassenaar T., Perez I., Fellmann T., Loudjani P., Tubiello F., Grandgirar D., Monni S., Biala K. (2010). Evaluation of the livestock sector's contribution to the EU greenhouse gas emissions (GGELS). European Commission, Joint Research Centre, Brussels.

Lindberg, C., \& Leflaive, X. (2015). The water-energy-food-nexus: The imperative of policy coherence for sustainable development. Coherence for Development-Better Policies for Better Lives-Organization for Economic Co-operation and Development, (6), 12.

Liu, J., Hertel, T. W., Taheripour, F., Zhu, T., \& Ringler, C. (2014). International trade buffers the impact of future irrigation shortfalls. Global Environmental Change, 29, 22-31, doi: 10.1016/j.gloenvcha.2014.07.010.

Lobell, D. B., \& Field, C. B. (2007). Global scale climate-crop yield relationships and the impacts of recent warming. Environmental research letters, 2(1), 014002, doi: 10.1088/17489326/2/1/014002

Lopez-Gunn, E., Zorrilla, P., Prieto, F., \& Llamas, M. R. (2012). Lost in translation? Water efficiency in Spanish agriculture. Agricultural Water Management, 108, 83-95, doi: 10.1016/j.agwat.2012.01.005.

MAPA (2001). Plan Nacional de Regadíos Horizonte 2008. Madrid: Ministerio de Agricultura, Pesca y Alimentación.

Marangoni, G., Tavoni, M., Bosetti, V., Borgonovo, E., Capros, P., Fricko, O., Gernaat, D. E. H. J., Guivarch, C., Havlik, P., Huppmann, D., Johnson, N., Karkatsoulis, P., Keppo, I., Krey, V., Ó Broin, E., Price, J. \& van Vuuren, D. P. (2017). Sensitivity of projected long-term CO 2 emissions across the Shared Socioeconomic Pathways. Nature Climate Change, 7(2), 113, doi: 10.1038/NCLIMATE3199.

Marchal, V., Dellink, R., van Vuuren, D., Clapp, C., Château, J., Lanzi, E., ... \& van Vliet, J. (2012). OECD environmental outlook to 2050: the consequences of inaction. OECD Publishing: Paris (France). 
Martinez, P., Blanco, M. \& Castro-Campos, B. (2018). The Water-Energy-Food Nexus: A FuzzyCognitive Mapping Approach to Support Nexus-Compliant Policies in Andalusia (Spain). Water, 10(5), 664, doi:10.3390/w10050664.

Massot, A. (2016). Research for Agri-Comitee - Agriculture in Andalusia. Directorate General for Internal Policies, doi: 10.2861/875069.

Mayor, B., López-Gunn, E., Villarroya, F. I., \& Montero, E. (2015). Application of a waterenergy-food nexus framework for the Duero river basin in Spain. Water International, 40(56), 791-808, doi: 10.1080/02508060.2015.1071512.

Morillo, J. G., Martín, M., Camacho, E., Díaz, J. R., \& Montesinos, P. (2015). Toward precision irrigation for intensive strawberry cultivation. Agricultural Water Management, 151, 43-51, doi: 10.1016/j.agwat.2014.09.021.

Moss, R. H., Edmonds, J. A., Hibbard, K. A., Manning, M. R., Rose, S. K., Van Vuuren, D. P., ... \& Meehl, G. A. (2010). The next generation of scenarios for climate change research and assessment. Nature, 463(7282), 747, doi: 10.1038/nature08823.

Misthos, L. M., Messaris, G., Damigos, D., \& Menegaki, M. (2017). Exploring the perceived intrusion of mining into the landscape using the fuzzy cognitive mapping approach. Ecological engineering, 101, 60-74, doi: 10.1016/j.ecoleng.2017.01.015.

Müller, C. \& Robertson, R.D. (2014). Projecting future crop productivity for global economic modeling. Agr Econ 45 (1): 37-50, doi: 10.1111/agec.12088.

Nelson, G.C., Rosegrant, M.W., Palazzo, A., Gray, I., Ingersoll, C., Robertson, R., Tokgoz, S., Zhu, T., Sulser, T.B., Ringler, C., Msangi, S., \& You, L. (2010). Food security, farming, and climate change to 2050: Scenarios, results, policy options. Int Food Policy Res Inst. Available at: http://www.ifpri.org/publication/food-security-farming-and-climate-change-2050.

Nelson, G. C., Van Der Mensbrugghe, D., Ahammad, H., Blanc, E., Calvin, K., Hasegawa, T., Havlik, P., Heyhoe, E., Kyle, P., Lotze-Campen, H., von Lampe, M., Mason, D., van Meijl, H., Müller, C., Reilly, J., Robertson, R., Sands, R. D., Schmitz, C., Tabeau, A., Takahashi, K., Valin, H \& Willenbockel, D. (2014). Agriculture and climate change in global scenarios: why don't the models agree. Agricultural Economics, 45(1), 85-101., doi: 10.1111/agec.12091.

Norton, J. (2015). An introduction to sensitivity assessment of simulation models. Environmental Modelling \& Software, 69, 166-174, doi: 10.1016/j.envsoft.2015.03.020. 
Noy, C. (2008). Sampling knowledge: The hermeneutics of snowball sampling in qualitative research. International Journal of social research methodology, 11(4), p. 327-344, doi: $10.1080 / 13645570701401305$.

O’Neill, B. C., Kriegler, E., Ebi, K. L., Kemp-Benedict, E., Riahi, K., Rothman, D. S., ... \& Levy, M. (2017). The roads ahead: Narratives for shared socioeconomic pathways describing world futures in the 21st century. Global Environmental Change, 42, 169-180, doi: 10.1016/j.gloenvcha.2015.01.004.

O’Neill, B. C., Kriegler, E., Riahi, K., Ebi, K. L., Hallegatte, S., Carter, T. R., Mathur, R. \& van Vuuren, D. P. (2014). A new scenario framework for climate change research: the concept of shared socioeconomic pathways. Climatic change, 122(3), 387-400, doi: 10.1007/s10584-013-0905-2.

OECD (2017). The Land-Water-Energy Nexus: Biophysical and Economic Consequences, OECD Publishing, Paris. doi: http://dx.doi.org/10.1787/9789264279360-en.

OECD (2013). Water and Climate Change Adaptation: Policies to Navigate Uncharted Waters, OECD Studies on Water, OECD Publishing.

Özesmi, U., \& Özesmi, S. L. (2004). Ecological models based on people's knowledge: a multistep fuzzy cognitive mapping approach. Ecological modelling, 176(1-2), 43-64.

Olazabal, M., Chiabai, A., Foudi, S., \& Neumann, M. B. (2018). Emergence of new knowledge for climate change adaptation. Environmental Science \& Policy, 83, 46-53, doi: 10.1016/j.envsci.2018.01.017.

Papageorgiou, E., \& Salmeron, J.L. (2013). A review of fuzzy cognitive maps research during the last decade. IEEE Transactions on Fuzzy Systems, 21(1), p. 66-79, doi: 10.1109/TFUZZ.2012.2201727.

Papageorgiou, E., \& Kontogianni, A. (2012). Using fuzzy cognitive mapping in environmental decision-making and management: a methodological primer and an application. In International Perspectives on Global Environmental Change. IntechOpen.

Pérez-Blanco, C. D., Delacámara, G., \& Gómez, C. M. (2015). Water charging and water saving in agriculture. Insights from a Revealed Preference Model in a Mediterranean basin. Environmental Modelling \& Software, 69, 90-100, doi: 0.1016/j.envsoft.2015.03.006. 
Peña-Gallardo, M., Gámiz-Fortís, S. R., Castro-Diez, Y., \& Esteban-Parra, M. J. (2016). Comparative analysis of drought indices in Andalusia during the period 1901-2012. Cuadernos de Investigacion Geográfica, 42(1), 67-88, doi: 10.18172/cig.2946.

Pérez Domínguez, I., Fellmann, T., Weiss, F., Witzke, P., Barreiro-Hurlé, J., Himics, M., Jansson, T., Salputra, G., Leip, A. (2016). An economic assessment of GHG mitigation policy options for EU agriculture (ECAMPA 2). JRC Science for Policy Report, EUR 27973 EN, doi: $10.2791 / 84346$.

Pérez Domínguez, I. (2006): Greenhouse Gases: Inventories, Abatement Costs and Markets for Emission Permits in European Agriculture - A Modelling Approach, Peter Lang, Frankfurt a.M.

Perry, C., Steduto, P., \& Karajeh, F. (2017). DOES IMPROVED IRRIGATION TECHNOLOGY SAVE WATER?. Food and Agriculture Organization: Rome, Italy.

Perry, C., Steduto, P., Allen, R. G., \& Burt, C. M. (2009). Increasing productivity in irrigated agriculture: Agronomic constraints and hydrological realities. Agricultural Water Management, 96(11), 1517-1524, doi: 10.1016/j.agwat.2009.05.005.

Perry, C. (2007). Efficient irrigation; inefficient communication; flawed recommendations. Irrigation and drainage, 56(4), 367-378, doi: 10.1002/ird.323.

Pianosi, F., Beven, K., Freer, J., Hall, J. W., Rougier, J., Stephenso, D. B., \& Wagener, T. (2016). Sensitivity analysis of environmental models: A systematic review with practical workflow. Environmental Modelling \& Software, 79, 214-232, doi: 10.1016/j.envsoft.2016.02.008.

Reckien, D. (2014). Weather extremes and street life in India-Implications of Fuzzy Cognitive Mapping as a new tool for semi-quantitative impact assessment and ranking of adaptation measures. Global environmental change 26, 1-13, doi: 10.1016/j.gloenvcha.2014.03.005.

Reilly, J., \& Hohmann, N. (1993). Climate change and agriculture: the role of international trade. The American Economic Review, 83(2), 306-312.

Rocamora, C., Vera, J., \& Abadía, R. (2013). Strategy for efficient energy management to solve energy problems in modernized irrigation: analysis of the Spanish case. Irrigation Science, 31(5), 1139-1158, doi: 10.1007/s00271-012-0394-5. 
Rodriguez, D. J., Delgado, A., DeLaquil, P., \& Sohns, A. (2013). Thirsty energy. Water papers, World Bank, Washington, Available at: http://documents.worldbank.org/curated/en/2013/01/17932041/thirsty-energy.

Rodríguez-Díaz, J.A.; Camacho-Poyato, E.; \& Blanco-Pérez, M. (2011a). Evaluation of water and energy use in pressurized irrigation networks in Southern Spain. J. Irrig. Drain. Eng., 137, 644-650, doi: 10.1061/(ASCE)IR.1943-4774.0000338.

Rodríguez-Díaz, J.A., Pérez-Urrestarazu, L., Camacho-Poyato, E., \& Montesino, P. (2011b). The paradox of irrigation scheme modernization: More efficient water use linked to higher energy demand. Spanish Journal of Agricultural Research 2011b, 9, 1000-1008, doi: 10.5424/sjar/20110904-492-10.

Díaz, J. R., Luque, R. L., Cobo, M. C., Montesinos, P., \& Poyato, E. C. (2009). Exploring energy saving scenarios for on-demand pressurised irrigation networks. Biosystems engineering, 104(4), 552-561, doi: 10.1016/j.biosystemseng.2009.09.001.

Rosenzweig, C., Elliott, J., Deryng, D., Ruane, A. C., Müller, C., Arneth, A., Kenneth, J., Folberth, C., Glotter, M., Khabarov, N., Neumann, K., Piontek, F., Pugh, T. A. M., Schmid, E., Stehfest, E., Yang, H., \& Jones, J.W. (2014). Assessing agricultural risks of climate change in the 21st century in a global gridded crop model intercomparison. Proceedings of the National Academy of Sciences, 111(9), 3268-3273, doi: 10.1073/pnas.1222463110

Roudier, P., Andersson, J. C., Donnelly, C., Feyen, L., Greuell, W., \& Ludwig, F. (2016). Projections of future floods and hydrological droughts in Europe under a+ $2 \mathrm{C}$ global warming. Climatic Change, 135(2), 341-355, doi: 10.1007/s10584-015-1570-4

Salmoral, G., \& Garrido, A. (2015). The Common Agricultural Policy as a driver of water quality changes: the case of the Guadalquivir River Basin (southern Spain). Bio-based and Applied Economics 4(2), 103.

Saltelli, A., Aleksankina, K., Becker, W., Fennell, P., Ferretti, F., Holst, N., Li, S., \& Wu, Q. (2019). Why so many published sensitivity analyses are false: A systematic review of sensitivity analysis practices. Environmental Modelling \& Software, 114, 29-39, doi: 10.1016/j.envsoft.2019.01.012.

Saltelli, A., \& Annoni, P. (2010). How to avoid a perfunctory sensitivity analysis. Environmental Modelling \& Software, 25(12), 1508-1517, doi:10.1016/j.envsoft.2010.04.012.

Saltelli, A., Ratto, M., Andres, T., Campolongo, F., Cariboni, J., Gatelli, D., ... \& Tarantola, S. (2008). Global sensitivity analysis: the primer. John Wiley \& Sons. 
Saltelli, A. (2002). Sensitivity analysis for importance assessment. Risk analysis, 22(3), 579590, doi: 10.1111/0272-4332.00040.

Sampedro, D., \& Del Moral, L. (2014). Tres décadas de política de aguas en Andalucía. Cuadernos Geográficos 53(1), 36-67.

Sauer, T., Havlík, P., Schneider, U. A., Schmid, E., Kindermann, G., \& Obersteiner, M. (2010). Agriculture and resource availability in a changing world: The role of irrigation. Water Resources Research, 46(6), doi: 10.1029/2009wr007729.

Schmitz, C., Lotze-Campen, H., Gerten, D., Dietrich, J. P., Bodirsky, B., Biewald, A., \& Popp, A. (2013). Blue water scarcity and the economic impacts of future agricultural trade and demand. Water Resources Research, 49(6), 3601-3617, doi: 10.1002/wrcr.20188.

Seckler, D., Molden, D., \& Sakthivadivel, R. (2003). The concept of efficiency in water resources management and policy. In Kijne, J. W.; Barker, R.; Molden. D. (Eds.). Water productivity in agriculture: limits and opportunities for improvement. Wallingford, UK: CABI; Colombo, Sri Lanka: International Water Management Institute (IWMI) pp.37-51.

Shrestha, S., Ciaian, P., Himics, M., \& Van Doorslaer, B. (2013). Impacts of Climate Change on EU Agriculture. Review of Agricultural and Applied Economics 16(2), doi: 10.15414/raae.2013.16.02.24-39

Serraj R., \& Pingali P. L. (2019). Agriculture \& Food Systems to 2050: Global Trends, Challenges and Opportunities. World Scientific Publishing Company Pte. Limited.

Smajgl, A., \& Ward, J. (2013). The Water-Food-Energy Nexus in the Mekong Region. Springer, New York, doi: 10.1007/978-1-4614-6120-3

Solana-Gutiérrez, J., Rincón, G., Alonso, C., \& García-de-Jalón, D. (2017). Using fuzzy cognitive maps for predicting river management responses: A case study of the Esla River basin, Spain. Ecological Modelling, 360, 260-269., doi: 10.1016/j.ecolmodel.2017.07.010.

Sulser, T. B., Ringler, C., Zhu, T., Msangi, S., Bryan, E., \& Rosegrant, M. W. (2010). Green and blue water accounting in the Ganges and Nile basins: Implications for food and agricultural policy. Journal of Hydrology 384:276-291, doi: 10.1016/j.jhydro1.2009.10.003.

Tarjuelo, J. M., Rodriguez-Diaz, J. A., Abadía, R., Camacho, E., Rocamora, C., \& Moreno, M. A. (2015). Efficient water and energy use in irrigation modernization: Lessons from Spanish case studies. Agricultural Water Management, 162, 67-77, doi: 10.1016/j.agwat.2015.08.009. 
Tobey, J., Reilly, J., \& Kane, S. (1992). Economic implications of global climate change for world agriculture. Journal of Agricultural and Resource Economics, 195-204.

Tramberend, S., Wiberg, D., Wada, Y., Flörke, M., Fischer, G., Satoh, Y., Yillia, P., van Vliet, M., Hizsnyik, E., Fabiola Nava, L., Blokker, M., \& Hanasaki, N. (2015). Building global water use scenarios. International Institute for Applied Systems Analysis, Austria, Laxemburg.

Tubiello, F.N., Amthor, J.S., Kenneth, J.B., Donatelli, M., Easterling, W., Fischer, G., Gifford, R.M., Howden, M., Reilly, J., \& Rosenzweig, C. (2007). Crop response to elevated CO2 and world food supply. A comment on "Food for thought..." by Long et al., Science 312: 19181921, 2006. . European journal of agronomy, 26(3), 215-223.

UN (2015). General Assembly Resolution A/RES/70/1. Transforming our world: the 2030 Agenda for Sustainable Development.

UNFCCC (2015). Paris Agreement. United Nations, Geneva, Switzerland.

Van Diepen, C. V., Wolf, J., Van Keulen, H., \& Rappoldt, C. (1989). WOFOST: a simulation model of crop production. Soil use and management, 5(1), 16-24, doi: 10.1111/j.14752743.1989.tb00755.x.

Van der Sluis, T., Arts, B., Kok, K., Bogers, M., Busck, A. G., Sepp, K., \& Crouzat, E. (2018). Drivers of European landscape change: stakeholders' perspectives through Fuzzy Cognitive Mapping. Landscape Research, 1-19, doi: 10.1080/01426397.2018.1446074.

Van Doorslaer, B., Witzke, P., Huck, I., Weiss, F., Fellmann, T., Salputra, G., Jansson, T., Drabik D., Leip A. (2015). An economic assessment of GHG mitigation policy options for EU agriculture (EcAMPA). JRC Science for Policy Report, EUR 27097 EN, doi: 10.2791/180800.

Van Vuuren, D. P., Kriegler, E., O’Neill, B. C., Ebi, K. L., Riahi, K., Carter, T. R., Edmonds, J., Hallegatte, S., Kram, T., Mathur, R., \& Winkler, H. (2014). A new scenario framework for climate change research: scenario matrix architecture. Climatic Change, 122(3), 373-386, doi: 10.1007/s10584-013-0906-1.

Van Vuuren, D. P., Riahi, K., Moss, R., Edmonds, J., Thomson, A., Nakicenovic, N., Kram, T., Berkhout, F., Swart, R., Janetos, A., Rose, S. K., \& Arnell, N. (2012). A proposal for a new scenario framework to support research and assessment in different climate research communities. Global Environmental Change, 22(1), 21-35, doi: 10.1016/j.gloenvcha.2011.08.002.

Van Vuuren, D. P., Edmonds, J., Kainuma, M., Riahi, K., Thomson, A., Hibbard, K., Hurtt, G. C., Kram, T., Krey, V., Lamarque, J., Masui, T., Meinshausen, M., Nakicenovic, N., Smith, S., \& 
Rose, S. K. (2011). The representative concentration pathways: an overview. Climatic change, 109(1-2), 5, doi: 10.1007/s10584-011-0148-z.

Vanwindekens, F. M., Stilmant, D., \& Baret, P. V. (2013). Development of a broadened cognitive mapping approach for analysing systems of practices in social-ecological systems. Ecological modelling 250, 352-362, doi: 10.1016/j.ecolmodel.2012.11.023

Vasslides, J. M., \& Jensen, O. P. (2016). Fuzzy cognitive mapping in support of integrated ecosystem assessments: Developing a shared conceptual model among stakeholders. Journal of environmental management, 166, 348-356., doi: 10.1016/j.jenvman.2015.10.038.

Voinov, A., Kolagani, N., McCall, M. K., Glynn, P. D., Kragt, M. E., Ostermann, F. O., Pierce, S.A., \& Ramu, P. (2016). Modelling with stakeholders-next generation. Environmental Modelling \& Software, 77, 196-220, doi: 10.1016/j.envsoft.2015.11.016.

Voinov, A., \& Bousquet, F. (2010). Modelling with stakeholders. Environmental Modelling \& Software, 25(11), 1268-1281, doi: 10.1016/j.envsoft.2010.03.007.

Von Lampe, M., Willenbockel, D., Ahammad, H., Blanc, E., Cai, Y., Calvin, K., Fujimori, S., Hasegawa, T., Havlik, P., Heyhoe, E., Kyle, P., Lotze-Campen, H., Mason, D., Nelson, G. C., Sands, R. D., Schmitz, C., Tabeau, A., Valin, H., va der Mensbrugghe, D., \& van Meijl, H. (2014). Why do global long-term scenarios for agriculture differ? An overview of the AgMIP global economic model intercomparison. Agricultural Economics, 45(1), 3-20, doi: 10.1111/agec.12086

Wada, Y., Flörke, M., Hanasaki, N., Eisner, S., Fischer, G., Tramberend, S., Satoh, Y., van Vliet, M. T. H., Yillia, P., Ringler, C., Burek, P., \& Wiberg, D. (2016). Modeling global water use for the 21st century: Water Futures and Solutions (WFaS) initiative and its approaches. Geoscientific Model Development, 9, 175-222, doi: 10.5194/gmd-9-175-2016.

Ward, F. A., \& Pulido-Velázquez, M. (2008). Water conservation in irrigation can increase water use. Proceedings of the National Academy of Sciences, 105(47), 18215-18220, doi: 10.1073pnas.0805554105.

WEF (2011). Global risks 2011 (6th ed.). Cologne/Geneva: World Economic Forum.

Walker, W. E., Harremoës, P., Rotmans, J., Van Der Sluijs, J. P., Van Asselt, M. B., Janssen, P., \& Krayer von Krauss, M. P. (2003). Defining uncertainty: a conceptual basis for uncertainty management in model-based decision support. Integrated assessment, 4(1), 5-17., doi: 10.1076/iaij.4.1.5.16466. 
Wiebe, K., Lotze-Campen, H., Sands, R., Tabeau, A., van der Mensbrugghe, D., Biewald, A., ... \& Müller, C. (2015). Climate change impacts on agriculture in 2050 under a range of plausible socioeconomic and emissions scenarios. Environmental Research Letters, 10(8), 085010, doi: 10.1088/1748-9326/10/8/085010.

Wildenberg, M., Bachhofer, M., Adamescu, M., De Blust, G., Diaz-Delgadod, R., Isak, K. G. Q., Skov, F., \& Riku, V. (2010). Linking thoughts to flows-Fuzzy cognitive mapping as tool for integrated landscape modelling. In Proceedings of the 2010 International Conference on integrative landscape modeling: linking environmental, social and computer science (Vol. 3, p. 5).

Zhao, G., Webber, H., Hoffmann, H., Wolf, J., Siebert, S., \& Ewert, F. (2015). The implication of irrigation in climate change impact assessment: a European-wide study. Global change biology, 21(11), 4031-4048, doi: 10.1111/gcb.13008.

Ziv, G., Watson, E., Young, D., Howard, D. C., Larcom, S. T., \& Tanentzap, A. J. (2018). The potential impact of Brexit on the energy, water and food nexus in the UK: A fuzzy cognitive mapping approach. Applied Energy, 210, 487-498, doi: 10.1016/j.apenergy.2017.08.033. 
Annexes 
Annex 1: LPJmL and WOFOST simulated yields changes in 2030 for wheat, maize, soybean and rapeseed under different climate scenarios (\% change relative to baseline).

\begin{tabular}{|c|c|c|c|c|c|c|c|c|}
\hline \multirow{2}{*}{$\begin{array}{l}\text { Country } \\
\text { WHEAT }\end{array}$} & \multicolumn{8}{|c|}{ Climate scenarios } \\
\hline & 45_HAD_CO2 & 85_HAD_CO2 & 45_IPSL_CO2 & 85_IPSL_CO2 & 45_HAD_noCO2 & 85_HAD_noCO2 & 45_IPSL_noCO2 & 85_IPSL_noCO2 \\
\hline EU-28 & 6.1 & 2.0 & 2.5 & 1.8 & 0.3 & -5.2 & -2.9 & -5.3 \\
\hline USA & 0.1 & 6.1 & 2.4 & 1.2 & -4.9 & -0.4 & -2.8 & -5.2 \\
\hline CAN & 14.5 & 10.7 & -4.3 & 4.0 & 7.9 & 2.2 & -10.3 & -3.9 \\
\hline ANZ & 3.4 & -4.9 & 0.6 & -0.8 & -1.6 & -11.0 & -4.4 & -7.1 \\
\hline JAP & 2.5 & 6.7 & 3.2 & 4.6 & -4.0 & -1.0 & -0.1 & 0.5 \\
\hline BRA & 3.4 & 1.5 & 1.8 & 1.6 & -4.6 & -8.9 & -5.5 & -8.1 \\
\hline MAIZE & 45_HAD_CO2 & 85_HAD_CO2 & 45_IPSL_CO2 & 85_IPSL_CO2 & 45_HAD_noCO2 & 85_HAD_noCO2 & 45_IPSL_noCO2 & 85_IPSL_noCO2 \\
\hline USA & 6.0 & 2.3 & 0.2 & 3.4 & 1.6 & -3.8 & -4.2 & -2.1 \\
\hline ARG & 1.5 & 13.8 & -5.7 & 4.0 & -3.5 & 7.4 & -10. & -1.7 \\
\hline BRA & -1.7 & -1.8 & -2.6 & -3.3 & -2.4 & -2.8 & -3.2 & -4.2 \\
\hline MEX & 8.0 & 5.1 & -2.1 & 2.1 & 5.6 & 2.2 & -5.0 & -1.7 \\
\hline JAP & 2.0 & 1.1 & 2.0 & 4.1 & 0.1 & -1.0 & 1.2 & 2.8 \\
\hline EU-28 & -17.61 & -9.87 & -2.06 & -4.57 & -17.87 & -10.27 & -2.46 & -5.06 \\
\hline SOYBEAN & 45_HAD_CO2 & 85_HAD_CO2 & 45_IPSL_CO2 & 85_IPSL_CO2 & 45_HAD_noCO2 & 85_HAD_noCO2 & 45_IPSL_noCO2 & 85_IPSL_noCO2 \\
\hline USA & 14.8 & 11.5 & 5.1 & 8.5 & 4.3 & -2.3 & -5.1 & -4.6 \\
\hline BRA & 6.0 & 2.9 & 3.8 & 2.6 & -5.8 & -12.3 & -7.1 & -11.2 \\
\hline ARG & 13.4 & 25.6 & -8.0 & 14.7 & -1.4 & 6.1 & -22.7 & -6.0 \\
\hline EU-28 & 4.5 & 7.3 & 7.6 & 9.4 & -2.8 & -1.8 & 1.0 & 1.1 \\
\hline $\mathrm{CHI}$ & 10.8 & 10.0 & 9.0 & 9.1 & 1.2 & -1.8 & 0.6 & -1.5 \\
\hline RAPE & 45_HAD_CO2 & 85_HAD_CO2 & 45_IPSL_CO2 & 85_IPSL_CO2 & 45_HAD_noCO2 & 85_HAD_noCO2 & 45_IPSL_noCO2 & 85_IPSL_noCO2 \\
\hline CAN & 15.6 & 12.1 & -7.2 & 5.1 & 8.3 & 2.5 & -13.6 & -3.7 \\
\hline EU-28 & 1.2 & 1.8 & 3.8 & 4.0 & -6.2 & -7.7 & -3.4 & -5.5 \\
\hline ANZ & 4.9 & -6.8 & -5.3 & -5.1 & -1.0 & -14.0 & -10.9 & -12.5 \\
\hline $\mathrm{CHI}$ & 6.1 & 7.2 & 8.3 & 7.7 & 0.4 & -0.2 & 2.8 & 0.7 \\
\hline
\end{tabular}

Country: Canada (CAN), United States (USA), Australia and New Zealand (ANZ), Japon (JAP), Brazil (BRA), Argentina (ARG), Mexico (MEX), China (CHI). 
Annex 2: Wheat exports from major exporters under different climate scenarios (\% change relative to baseline in 2030). Baseline values in thousand tons. Source: CAPRI model.

\begin{tabular}{|c|c|c|c|c|c|}
\hline \multicolumn{6}{|c|}{ From EU to } \\
\hline & Baseline & 45_Had_CO 2 & 85_Had_CO 2 & 45_Had_noCO 2 & 85_Had_noCO 2 \\
\hline REU & 1025 & $-5.7 \%$ & $-9.4 \%$ & $-1.0 \%$ & $-4.0 \%$ \\
\hline MENA & 16739 & $-13.5 \%$ & $-21.5 \%$ & $2.6 \%$ & $-5.5 \%$ \\
\hline SSA & 7715 & $-12.3 \%$ & $-19.6 \%$ & $-2.8 \%$ & $-10.6 \%$ \\
\hline OSA & 463 & $-19.9 \%$ & $-39.7 \%$ & $0.1 \%$ & $-21.8 \%$ \\
\hline IND & 32 & $-84.9 \%$ & $-81.5 \%$ & $22.3 \%$ & $63.9 \%$ \\
\hline SEA & 1300 & $-25.7 \%$ & $-29.4 \%$ & $-0.2 \%$ & $-5.0 \%$ \\
\hline OAS & 1505 & $-44.3 \%$ & $-48.3 \%$ & $4.9 \%$ & $-0.6 \%$ \\
\hline \multicolumn{6}{|c|}{ From USA to } \\
\hline & Baseline & 45_Had_CO 2 & 85_Had_CO 2 & 45_Had_noCO 2 & 85_Had_noCO \\
\hline EU28 & 556 & $27.4 \%$ & $64.4 \%$ & $7.1 \%$ & $34.5 \%$ \\
\hline REU & 5 & $52.0 \%$ & $66.4 \%$ & $-1.6 \%$ & $6.5 \%$ \\
\hline MENA & 1691 & $19.0 \%$ & $47.3 \%$ & $2.2 \%$ & $24.0 \%$ \\
\hline SSA & 3181 & $11.0 \%$ & $24.4 \%$ & $-0.6 \%$ & $10.2 \%$ \\
\hline CAN & 312 & $-25.8 \%$ & $-8.7 \%$ & $-24.4 \%$ & $-7.5 \%$ \\
\hline BRA & 895 & $-4.4 \%$ & $-2.8 \%$ & $-1.4 \%$ & $0.0 \%$ \\
\hline OSA & 8584 & $0.5 \%$ & $5.0 \%$ & $-4.4 \%$ & $-0.6 \%$ \\
\hline SEA & 11180 & $-1.1 \%$ & $2.7 \%$ & $-0.1 \%$ & $3.0 \%$ \\
\hline OAS & 3438.1 & $-32.8 \%$ & $-30.2 \%$ & $-1.8 \%$ & $2.6 \%$ \\
\hline \multicolumn{6}{|c|}{ From Canada to } \\
\hline & Baseline & 45_Had_CO 2 & 85_Had_CO 2 & 45_Had_noCO 2 & 85_Had_noCO \\
\hline EU28 & 29 & $42.2 \%$ & $54.2 \%$ & $34.7 \%$ & $45.9 \%$ \\
\hline REU & 80 & $32.0 \%$ & $28.4 \%$ & $-0.7 \%$ & $1.1 \%$ \\
\hline MENA & 12438 & $20.1 \%$ & $14.5 \%$ & $14.0 \%$ & $6.1 \%$ \\
\hline SSA & 1141 & $44.2 \%$ & $41.9 \%$ & $26.1 \%$ & $20.5 \%$ \\
\hline USA & 3123 & $2.0 \%$ & $-9.7 \%$ & $19.4 \%$ & $9.4 \%$ \\
\hline BRA & 524 & $36.8 \%$ & $15.6 \%$ & $20.2 \%$ & $-1.9 \%$ \\
\hline OSA & 3548 & $23.5 \%$ & $17.3 \%$ & $10.2 \%$ & $2.8 \%$ \\
\hline SEA & 806 & $24.0 \%$ & $19.1 \%$ & $23.8 \%$ & $15.0 \%$ \\
\hline OAS & 383 & $-21.1 \%$ & $-21.8 \%$ & $33.2 \%$ & $23.3 \%$ \\
\hline \multicolumn{6}{|c|}{ From Australian and New Zealand to } \\
\hline & Baseline & 45_Had_CO 2 & 85_Had_CO 2 & 45_Had_noCO & 85_Had_noCO \\
\hline EU28 & 28 & $14.4 \%$ & $8.7 \%$ & $11.3 \%$ & $9.6 \%$ \\
\hline MENA & 944 & $-6.0 \%$ & $-22.7 \%$ & $-8.9 \%$ & $-23.3 \%$ \\
\hline SSA & 2259 & $8.3 \%$ & $-9.3 \%$ & $1.3 \%$ & $-14.1 \%$ \\
\hline SEA & 9707 & $-2.2 \%$ & $-8.9 \%$ & $0.6 \%$ & $-5.9 \%$ \\
\hline OAS & 2028 & $-1.1 \%$ & $-26.6 \%$ & $5.1 \%$ & $-19.9 \%$ \\
\hline
\end{tabular}

Country/Regions: Rest of European Union (REU), Middle East and North Africa (MENA), Sub-Saharan Africa (SSA), Canada (CAN), Brazil (BRA), Argentina (ARG), Other South and Central America (OSA), South East Asia (SEA), India (IND), China (CHI), Other Asia (OAS). 
Annex 3: Stakeholder survey template.

Sustainable Integrated Management FOR the NEXUS of water-land-food-energy-climate for a resource-efficient Europe (SIM4NEXUS)

Caso de estudio: Andalucía

Encuesta sobre el nexo agua-agricultura-energía en un contexto de cambio climático

\begin{tabular}{|l|l|}
\hline Organización: & Fecha: \\
\hline Nombre y Apellidos: & Email: \\
\hline Puesto: & Tlf: \\
\hline
\end{tabular}

1. ¿Cuál es el papel de su organización en el sector/es del agua/agricultura/energía en Andalucía? (e.g., usuario, gestor, toma de decisiones en materia de políticas, investigación, formación)

2. ¿De qué manera influye su organización en la toma de decisiones en materia de políticas agrarias o ambientales?

3. Principales foros/plataformas/congresos/seminarios en los que participa su organización

4. Complete la matriz indicando las interrelaciones entre los distintos componentes clima, agua, alimentación, suelo y energía en Andalucía. Incluimos algunas interacciones a modo de ejemplo: 


\begin{tabular}{|c|c|c|c|c|c|}
\hline & Clima & Agua & $\begin{array}{c}\text { Agricultura/ } \\
\text { Alimentación }\end{array}$ & $\begin{array}{c}\text { Uso del } \\
\text { suelo }\end{array}$ & Energía \\
\hline Clima & & & & \\
\hline Agua & & & & \\
\hline $\begin{array}{c}\text { Agricultura/ } \\
\text { Alimentación }\end{array}$ & & & & \\
\hline $\begin{array}{c}\text { Uso del } \\
\text { suelo }\end{array}$ & & & & \\
\hline Energía & & & & \\
\hline
\end{tabular}

5. ¿Considera que las políticas existentes responden a los retos actuales en la gestión integral sostenible de los recursos? ¿Considera que tienen en cuenta el nexo aguaagricultura-energía?

6. ¿Cómo mejoraría estas políticas para promover el uso eficiente de los recursos?

7. ¿Conoce alguna iniciativa que se haya llevado a cabo anteriormente o en la actualidad para promover la gestión sostenible de los recursos en el territorio de Andalucía (proyectos de investigación, planes o estrategias locales, etc.)?

Compromiso de confidencialidad: Los datos personales recogidos en esta encuesta tienen como única finalidad proceder al tratamiento adecuado de la información y en ningún caso serán transmitidos a terceros sin consentimiento previo. Asimismo, el equipo investigador se compromete a respetar la confidencialidad de la información recogida en la encuesta, que se procesará y presentará de forma anónima. 
Annex 4: First stakeholder workshop agenda.

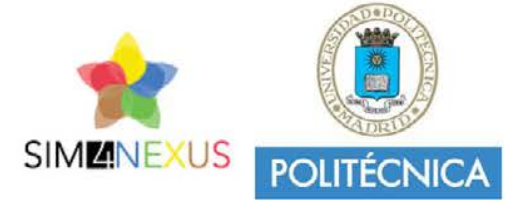

Organizado por el equipo UPM-SIM4NEXUS en colaboración con la Consejería de Agricultura, Pesca y Desarrollo rural de la Junta de Andalucía
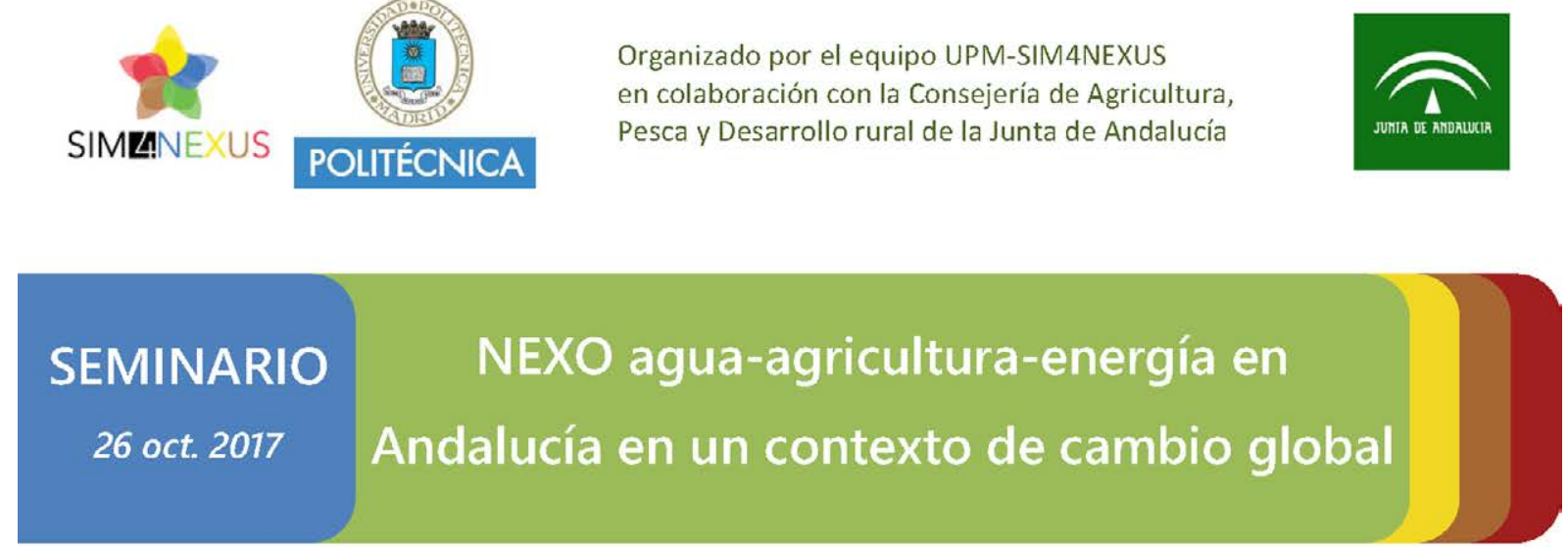

$10: 00$ a $10: 10$

Apertura y bienvenida

Rafael Peral. Secretario General de Agricultura y Alimentación

$10: 10$ a $10: 25$

Proyecto SIM4NEXUS: objetivos y alcance

Maria Blanco. Universidad Politécnica de Madrid

$10: 25$ a $10: 45$

Presentación del caso de estudio de Andalucía

Pilar Martinez. Universidad Politécnica de Madrid

\section{Pausa café}

$11: 00$ a $14: 00$

Taller: Nexo agua-agricultura-energía

en Andalucía

\section{Comida}

\section{$15: 00$ a $16: 00$}

Discusión y conclusiones

Consejería de Agricultura, Pesca y Desarrollo Rural

C/ Tabladilla, s/n, Sevilla

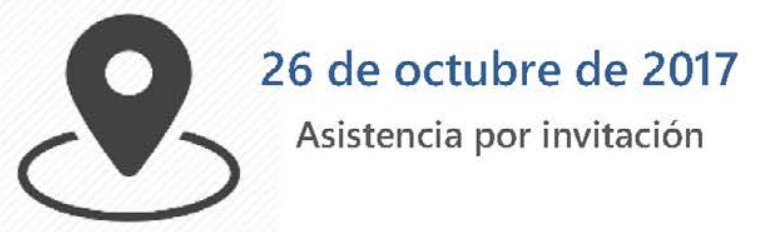

This project has received funding from the European Union's Horizon 2020 research and innovation programme under grant agreement No 689150 SIM4NEXUS

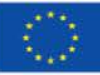


Annex 5: Second stakeholder workshop agenda.
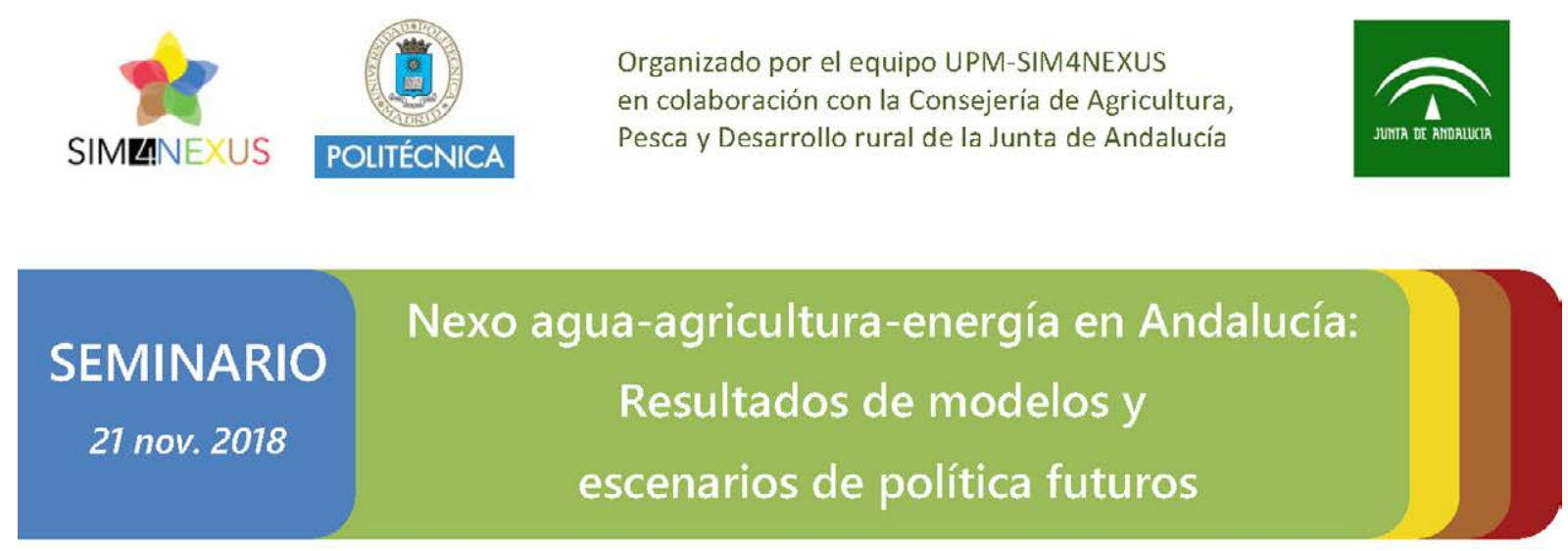

09:15 a 09:30

\section{Apertura y bienvenida}

Rafael Peral. Secretario General de Agricultura y Alimentación

\section{9:30 a $10: 00$}

Proyecciones a 2030/2050 para Andalucía: modelos CAPRI y E3ME

Maria Blanco. Universidad Politécnica de Madrid

$\checkmark$ Presentación de resultados de los modelos sectoriales

$\checkmark$ Preguntas y discusión

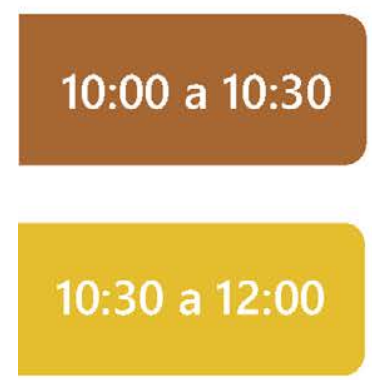

\section{Café}

Mesa redonda: "Políticas públicas para la promoción del uso eficiente de los recursos y la economía baja en carbono en Andalucía"

\section{$\checkmark$ Casos de éxito de políticas \\ $\checkmark$ Definición de escenarios futuros}

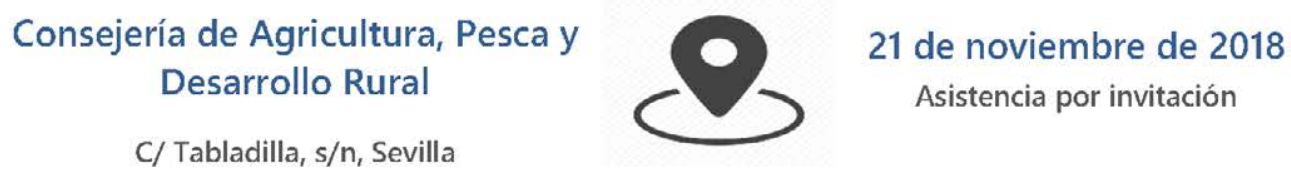

This project has received funding from the European Union's Horizon 2020 research and innovation programme under grant agreement No 689150 SIM4NEXUS

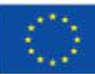

SIMZINEXUS 